Utah State University

DigitalCommons@USU

\title{
Assessment of Aspen Ecosystem Vulnerability to Climate Change for the Uinta-Wasatch- Cache and Ashley National Forests, Utah
}

Janine Rice

Tim Bardsley

Pete Gomben

Dustin Bambrough

Stacey Weems

Allen Huber

See next page for additional authors

Follow this and additional works at: https://digitalcommons.usu.edu/aspen_bib

Part of the Agriculture Commons, Ecology and Evolutionary Biology Commons, Forest Sciences

Commons, Genetics and Genomics Commons, and the Plant Sciences Commons

\section{Recommended Citation}

Rice, J., T. Bardsley, P. Gomben, D. Bambrough, S. Weems, A. Huber, and L. A. Joyce. 2017. Assessment of Aspen Ecosystem Vulnerability to Climate Change for the Uinta-Wasatch-Cache and Ashley National Forests, Utah. Gen. Tech. Rep. RMRS-GTR-366. US Department of Agriculture, Forest Service, Rocky Mountain Research Station, Fort Collins, C0.67 p.

This Book is brought to you for free and open access by the Aspen Research at DigitalCommons@USU. It has been accepted for inclusion in Aspen Bibliography by an authorized administrator of DigitalCommons@USU. For more information, please contact

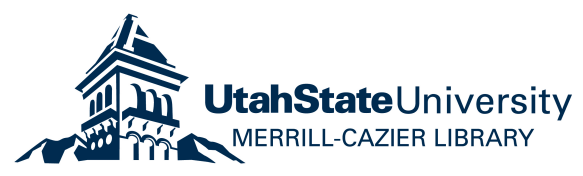




\section{Authors}

Janine Rice, Tim Bardsley, Pete Gomben, Dustin Bambrough, Stacey Weems, Allen Huber, and Linda A. Joyce 


\section{Assessment of Aspen Ecosystem Vulnerability to Climate Change for the Uinta-Wasatch- Cache and Ashley National Forests, Utah}

Janine Rice, Tim Bardsley, Pete Gomben, Dustin Bambrough, Stacey Weems, Allen Huber, and Linda A. Joyce 
Rice, Janine; Bardsley, Tim; Gomben, Pete; Bambrough, Dustin; Weems, Stacey; Huber, Allen; Joyce, Linda A. 2017. Assessment of aspen ecosystem vulnerability to climate change for the Uinta-Wasatch-Cache and Ashley National Forests, Utah. Gen. Tech. Rep. RMRS-GTR-366. Fort Collins, CO: U.S. Department of Agriculture, Forest Service, Rocky Mountain Research Station. 67 p.

\begin{abstract}
Aspen ecosystems are valued because they add biodiversity and ecological value to the landscape. They provide rich and productive habitats and increase aesthetic value. Climate change poses the risk of altering and disrupting these ecosystems, and it may worsen the effects of non-climate stressors. To provide scientific information for land managers facing the challenge of helping aspen ecosystems adapt to climate change, we developed an aspen vulnerability assessment on the Uinta-Wasatch-Cache and Ashley National Forests. Literature-based information and expert elicitation are used to define (a) components of sensitivity and exposure to climate change and (b) the capacity of these ecosystems to adapt to expected changes. Aspen ecosystems benefit from fire and quickly reproduce. Yet, aspen trees are susceptible to drought and heat that is projected to become more frequent and intense in the future. Some aspen-associated plant and animal species may benefit from the expected changes in disturbance regimes and stand structure, while others may experience population reductions or stress as a result of drought and heat. Overall, vulnerability is defined as moderate because although persistence of aspen ecosystems is likely, a dynamic spatial and temporal response to climate change is expected.
\end{abstract}

Keywords: exposure, sensitivity, adaptive capacity, vulnerability assessment 


\section{Authors}

Janine Rice is a Research Ecologist with Rice Consulting LLC Fort Collins, Colorado.

Tim Bardsley is a Senior Service Hydrologist with the National Weather Service in Reno, Nevada.

Pete Gomben is the Environmental Coordinator with the Uinta-Wasatch-Cache National Forest in South Jordan, Utah.

Dustin Bambrough is the Ecosystem Staff Officer with the Ashley National Forest in Vernal, Utah.

Stacey Weems is a Soil Scientist with the Uinta-Wasatch-Cache National Forest in South Jordan, Utah.

Allen Huber is an Ecologist with the Ashley National Forest in Vernal, Utah.

Linda A. Joyce is a Quantitative Research Ecologist at the Rocky Mountain Research Station in Fort Collins, Colorado.

\section{Acknowledgments}

We wish to thank the following reviewers: Paul Rogers, Karen Mock, Sam St. Clair, Dale Bartos, and Wayne Shepperd. This project was funded by the Uinta-WasatchCache and Ashley National Forests. We also wish to thank Western Water Assessment for participating in this project.

All Rocky Mountain Research Station publications are published by U.S. Forest Service employees and are in the public domain and available at no cost. Even though U.S. Forest Service publications are not copyrighted, they are formatted according to U.S. Department of Agriculture standards and research findings and formatting cannot be altered in reprints. Altering content or formatting, including the cover and title page, is strictly prohibited. 


\section{Contents}

Aspen Vulnerability Summary..................... iv

Introduction. $\ldots \ldots \ldots \ldots \ldots \ldots \ldots \ldots \ldots \ldots \ldots \ldots \ldots \ldots \ldots \ldots \ldots \ldots \ldots \ldots$

Method of Vulnerability Assessment . . . . . . . . . . . . .

Aspen Distribution and Types . . . . . . . . . . . . . . 2

Persistent Aspen . . . . . . . . . . . . . . . . . . 3

Seral Aspen . . . . . . . . . . . . . . . . . . . . . . . 3

Riparian Aspen . . . . . . . . . . . . . . . . . 4

Vulnerability Assessment Framework . . . . . . . . . . . . . 4

\section{Climate in the Uinta-Wasatch-Cache and Ashley National}

Forests, Utah . . . . . . . . . . . . . . . . . 8

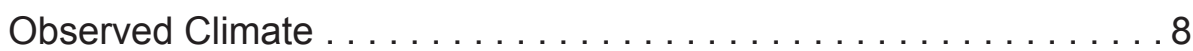

Temperature. . . . . . . . . . . . . . . . . . . 8

Precipitation. . . . . . . . . . . . . . . . . . . . . 9

Snow ............................... 9

Projected Changes in Climate. . . . . . . . . . . . . . . . . . . 11

Projected Trends for Snow . . . . . . . . . . . . . . . . . . 15

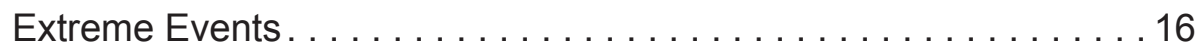

\section{Vulnerability of Uinta-Wasatch-Cache and Ashley National}

Forests Aspen Ecosystems to Climate Change . . . . . . . . . 18

Range Shift Capacity. . . . . . . . . . . . . . . . . 18

Southern Range Limit Proximity . . . . . . . . . . . . . . 18

Elevation Range Shift Capacity. . . . . . . . . . . . . . 18

Vulnerability of Aspen-Associated, Cold-Adapted Foundation

or Keystone Species to Climate Change . . . . . . . . . . 26

Understory Vegetation . . . . . . . . . . . . . . . . 27

Birds . . . . . . . . . . . . . . . . . . . . . . . . . 29

Limited Knowledge . . . . . . . . . . . . . . . . 31

Sensitivity to Extreme Climatic Events (Drought, Heat, Floods) . . . 32

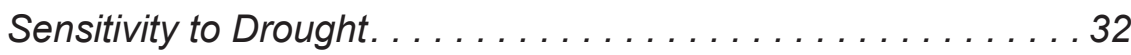

Sensitivity to Extreme Heat . . . . . . . . . . . . . . . . . . 34

Sensitivity to Floods. . . . . . . . . . . . . . . . . . 34

Intrinsic Adaptive Capacity . . . . . . . . . . . . . . . . . . . . . . 35

Factors That Strengthen Adaptive Capacity to

Climate Change. . . . . . . . . . . . . . . . . 35

Factors That Weaken Adaptive Capacity. . . . . . . . . . . . . 37

Dependence on Specific Hydrologic Condition . . . . . . . . . . . 37

Hydrologic Regime . . . . . . . . . . . . . . . . . . . . 37

Hydrologic Regime Changes and Effects on Aspen

Ecosystems . 
Potential for Climate Change to Exacerbate the Effects of

Non-Climate Stressors, or Vice Versa . . . . . . . . . . . 39

Climate Change and Herbivory . . . . . . . . . . . . . . . . . . 39

Climate Change, Fire, and Bark Beetle Outbreaks . . . . . . . . . 41

Fire. . . . . . . . . . . . . . . . . . . . . . 41

Conifer Bark Beetle Outbreaks in Seral Aspen . . . . . . . . . . 43

Climate Change, Insects and Diseases, Sudden Aspen

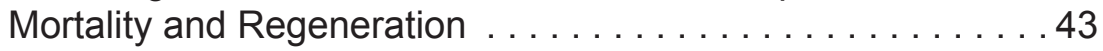

Likelihood of Managing or Alleviating Climate Change Effects . . . . 44

Climate Change Adaptation . . . . . . . . . . . . . . 44

Management Strategies. . . . . . . . . . . . . . . . . 45

References ........................... 48

Appendix A-Aspen Ecosystem Vulnerability Assessment. . . . . . . 61

Vulnerability Assessment Development Process . . . . . . . . . . 61

Summary of Uinta-Wasatch-Cache and Ashley National

Forests Aspen Ecosystem Vulnerability . . . . . . . . . 61

Appendix B-Climate Model Projections. . . . . . . . . . . . . . 62

Projections for Temperature and Precipitation (CMIP5) . . . . . . 62

Appendix C-Coupled Model Intercomparison Project Phase 5 . . . 66 


\section{Aspen Vulnerability Summary}

Aspen ecosystems: Aspen are the most widely distributed tree in North America with high ecological and social value. They are associated with less water use than other ecosystems, good quality forage and habitats, and rich biodiversity of plants, birds, and wildlife. These ecosystems are highly productive and are rich in soil nutrients. Their high aesthetic value promotes economic benefits through tourism. Aspen are more common in the Wasatch Range and less so in the Uinta Mountains of northeastern Utah. These aspen stand types can be (a) seral, in the process of succession to conifers, (b) in riparian areas, or (c) persistent, dominated by aspen. Seral stands may give way to conifer succession over time in the absence of disturbance, while persistent stands remain dominated by aspen over long periods. Seed reproduction is not commonly observed, and most aspen regeneration appears to be from root suckering.

\section{Aspen vulnerability to climate change: Moderate}

Current conditions: Most of the aspen stands on the Wasatch Range occur between 6,000 and 10,000 feet elevation, and in the Uinta Mountains, between 7,000 and 11,000 feet elevation. Fire suppression and stresses from drought, insects and diseases, and human land uses have contributed to the general decline in the amount of aspen cover. There are some small areas where aspen is expanding, however. Of the three aspen types (seral, persistent, or riparian), most aspen stands are mixed with conifers.

Exposure: More intense and frequent multi-year drought and extreme heat are expected to adversely affect aspen ecosystems, potentially causing mortality and/or hindering reproduction.

Sensitivity: Aspen trees at lower elevations and southerly aspects may be particularly vulnerable to more frequent and intense multi-year drought and heat. These conditions have recently been associated with rapid aspen decline in persistent and seral stands. The conditions can be compounded by insects, disease, and ungulate over-browsing.

Adaptive capacity: Ecosystem adaptive capacity to climate change may be raised by high biodiversity, which can expand the range of biotic responses to climate change. Seral stands have higher bird biodiversity than persistent stands. Aspen trees regenerate quickly and are benefitted by fire, which is likely to increase in frequency, size, and intensity in the future. Aspen trees can share root systems and can distribute water and nutrients to tree stems that may not have access to water. Leaf fluttering cools leaves and is an adaptive mechanism to heat. However, adaptive capacity is lowered by aspen's inability to compete with conifers, high susceptibility to a number of insects and diseases, and inability to adapt to climate warming and drying that exceed tolerance levels.

Non-climate stressors: Fire, insects and diseases, ungulate grazing, and competition with conifers may interact with climate warming and drying, and in some cases, they may exacerbate the adverse effects of non-climate stressors on aspen ecosystems. 


\section{Introduction}

Climate-driven changes associated with recent temperature warming have become increasingly apparent in western United States landscapes over the past decade. More frequent and severe fire and insect outbreaks, less snowpack at mid- and low-elevations, and shifts to earlier timing of snowmelt and runoff have been linked to recent warming (Bentz et al. 2009; Stewart 2009; Stewart et al. 2005; Westerling et al. 2014). Future warming is projected to add another 2 to $6^{\circ} \mathrm{F}$ to average temperatures by mid-century (see table 2 in Climate section). This warming brings the potential of ecological impacts that will combine with existing stressors in complex ways.

Natural resource managers are developing strategies to increase ecosystem resilience and adaptation in the face of climate change, and vulnerability assessment is a critical part of this process. Vulnerability is defined as the propensity or predisposition to be adversely affected, encompassing elements of sensitivity or susceptibility to harm and lack of ability to cope or adapt (IPCC 2014). Vulnerability assessment considers exposure, sensitivity, and adaptive capacity. The character, magnitude, and rate of climate variation to which a system is exposed, system sensitivity to those changes, and system resilience and adaptive ability to cope with changes, are all factors that when combined, define vulnerability (Glick et al. 2011). The goal of a vulnerability assessment is to identify the components of ecosystems and associated services that may be at risk from a changing climate, why they are vulnerable, and how existing stressors may interact to exacerbate vulnerability. Knowledge gained serves as a platform for land managers to identify and prioritize strategies and activities that can help minimize the impacts of climate change (Glick et al. 2011) and capitalize on any benefits from climate change.

This report presents an assessment of the vulnerability of aspen ecosystems to climate change on the Uinta-Wasatch-Cache and Ashley National Forests (NFs). It is a collaborative effort between the Rocky Mountain Research Station and these National Forests. Current scientific information in the literature is synthesized, vulnerability is ranked using seven criteria, and scientific experts and National Forest managers are engaged to review the vulnerability rankings and supporting documentation (see Appendix A for a summary of methods and vulnerability results). This report provides current scientific information relevant to the vulnerability of aspen ecosystems and reveals gaps where information is limited or non-existent. The assessment is intended to form a foundation of scientific information that can be updated as more becomes available. It can also be used to inform discussions in developing climate adaptation options for aspen ecosystems and for forest planning and NEPA documents. 


\section{Method of Vulnerability Assessment}

\section{Aspen Distribution and Types}

Aspen ecosystems exist in a wide variety of environmental conditions and have differing ecological patterns and dynamics in response to conditions. In this report, we divide aspen into functional types: persistent (sometimes referred to as stable), seral, and riparian. These three functional types are often integrated.

These three aspen types are found on the mountainous terrain of the Wasatch Range and Stansbury Mountains (collectively called the Wasatch Range from here forward) (fig. 1a) and in the east-west trending Uinta Mountains. Aspen coverage is present but less extensive in the Uinta Mountains (fig. 1b).

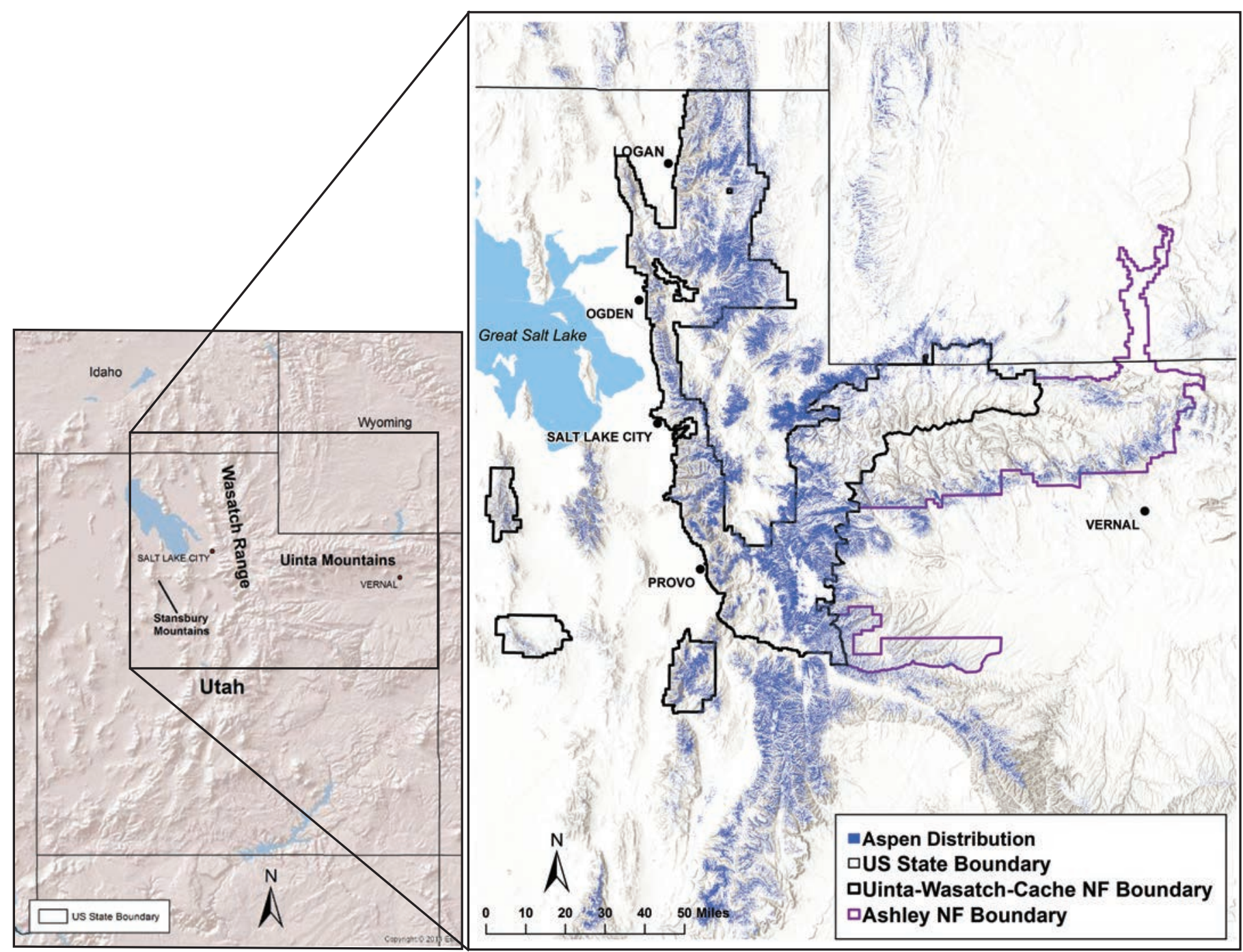

Figure 1-Aspen distribution in the Uinta-Wasatch-Cache and Ashley National Forests. Data from USDA 2013a. Note: Aspen types of seral, persistent, and riparian are not differentiated as this information is not available. 


\section{Persistent Aspen}

Rogers et al. (2014) define persistent aspen types as remaining dominated by aspen over long time periods ( $>80$ to 120 years), with little or no conifer invasion (fig. 2). Small-scale disturbances of individual or small groups of trees, termed "gap-phase" stand dynamics, characterize persistent aspen types that often have multiple age classes (Rogers et al. 2014). Stands are often of uneven age with basal area remaining relatively unchanged over time as small group or individual tree mortality events, such as insects, disease, or drought stress, allow canopy succession from smaller aspen trees (Mueggler 1985b; Rogers et al. 2014). Persistent aspen types were further differentiated by Rogers et al. (2014) as (a) elevation or aspect limited types typically on south-facing or moderate slopes, (b) terrain isolated types typically in snow pockets, avalanche chutes, isolated rocky slopes, or moraines, and (c) Colorado Plateau types on flat or modest slopes.

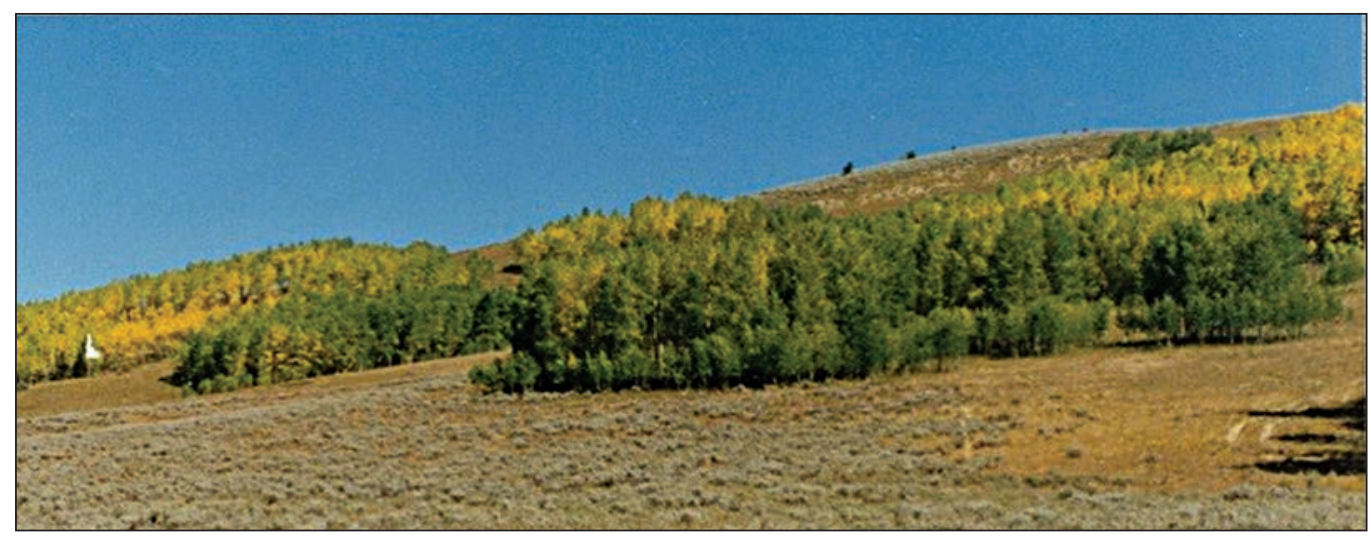

Figure 2-Persistent aspen on the Tavaputs Plateau, Ashley National Forest. Photo by A. Huber.

\section{Seral Aspen}

Seral aspen types are presumed to be in a state of transition to shade-tolerant conifers, with typically even-aged aspen stands giving way to conifer dominance over a period of decades or a century in the absence of disturbance (Rogers et al. 2014) (fig. 3). In the southern and central Rocky Mountains, seral aspen types dominate across these landscapes (Rogers et al. 2002). The initial stage of these stands is characterized

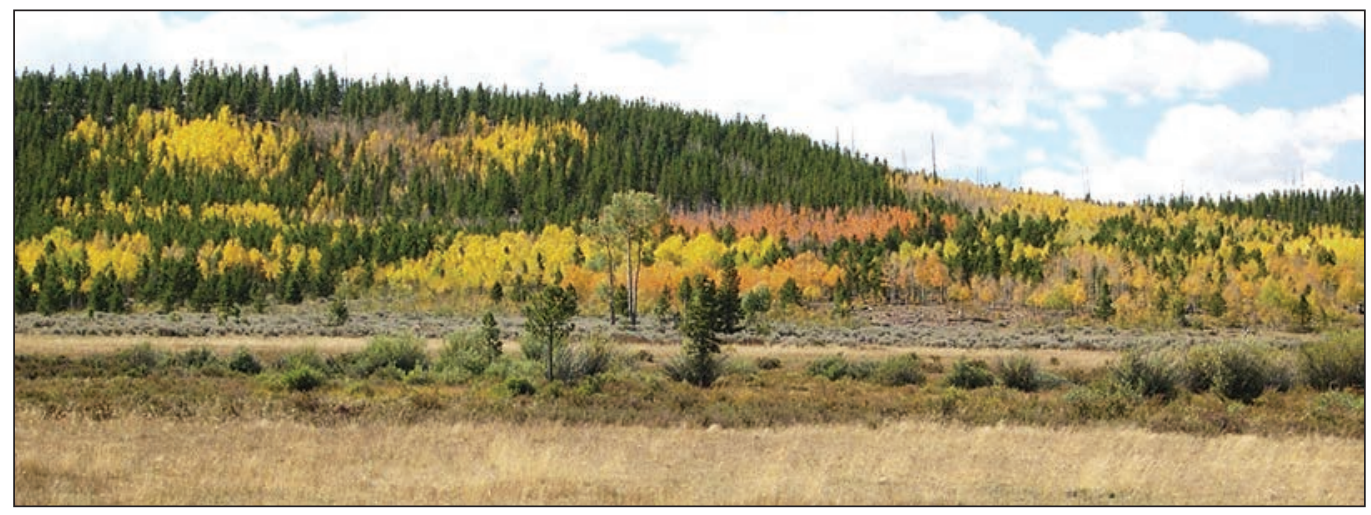

Figure 3-Seral Aspen in the Uinta Mountains, Ashley National Forest. Photo by A. Huber. 
by a stand-replacing disturbance that initiates aspen regeneration. Aspen trees typically regenerate through root suckering, although seed reproduction can occur and may be more common than previously thought (Krasnow and Stephens 2015; Long and Mock 2012; Rogers et al. 2014).

\section{Riparian Aspen}

These aspen types found near perennial or ephemeral streams or wetlands can be persistent or seral, but they are commonly seral. Riparian aspen are more resistant to wildfire than aspen found in other landscape types. They may have even greater biodiversity than other aspen types as a result of their proximity to water (Rogers et al. 2014). Water-sharing aspen ramets (suckers sprouting from aspen roots) can spread into dry upland areas where conditions allow. Many wildlife species utilize these areas for water and protective cover, thereby adding biodiversity in these areas. Wild and domestic ungulates have a high utilization of these productive and nutrient rich sites (Rogers and Mittanck 2014).

\section{Vulnerability Assessment Framework}

We take a holistic approach to assessing the climate change vulnerability of aspen ecosystems in the Uinta-Wasatch-Cache and Ashley NFs. This vulnerability assessment uses current scientific literature and expert elicitation to provide evidence for vulnerability rankings of aspen ecosystems. The vulnerability approach is based on the Northeastern Association of Fish and Wildlife Agencies (NEAFWA) model (Manomet 2012). This model has been applied in Massachusetts (Manomet 2010), 14 northeastern States (Manomet 2012), the Badlands National Park in South Dakota (Amberg et al. 2012), and the Gunnison Basin in Colorado (Neely et al. 2012). In this application, we have modified the original NEAFWA model such that 7 criteria are used to assess aspen vulnerability to climate change and current stressors for the mid$21^{\text {st }}$ century (table 1 ). This assessment synthesizes currently available information on how climate change may affect ecosystem function, disturbance regimes, and plant and animal species. Human influences that affect aspen ecosystems, which may interact with climate change, are also considered along with management activities that may alleviate stressors and climate change effects.

This approach allows for an efficient means to assess vulnerability of aspen ecosystems. Scientific studies conducted in these NFs are incorporated when available. When such local information is unavailable, we draw on studies that have been conducted in the Rocky Mountains, the western United States, or other areas with similar ecological characteristics. Vulnerability conclusions are contingent on the available information and we reveal where knowledge gaps exist. National Forest land manager input was used to organize information in a manner relevant to management activities. Expert elicitation from university experts, Forest Service researchers, and National Forest staff helps ensure that the scientific literature used to assess vulnerability is accurate and complete. These experts also provide input on vulnerability rankings. 
Table 1-Criteria and associated rationale used to establish the vulnerability to climate change for aspen ecosystem processes and biota. For each criterion, vulnerability can be assigned a score of either Very Low, Low, Moderate, High or Very High vulnerability.

\section{Range shift capacity}

Southern range limit proximity

- Ecosystems that are less than 125 miles north of their southern range limit have a higher vulnerability as unsuitable climates shifting northward are likely to adversely affect the ecosystem and cause a range contraction.

- Ecosystems that are more than 125 miles north of their southern range limit have a Low vulnerability as unsuitable climates may not shift far enough northward to adversely affect the ecosystem and cause a range contraction.

\section{Upslope migration potential}

Note: The elevation range shift potential of plants are likely to have a complex response to temperature warming with environmental factors as well as climate causing irregular range shifts. This criterion accounts for whether upslope area exists to make range shifts possible under climate change, and other potential restrictions to these shifts such as, suitable soils, ungulate browsing, disturbance, or microsite conditions may inhibit upslope migration.

- Biota living at high elevations (for example the alpine life zone or near peak tops) are likely to have a Very High vulnerability to climate change since upslope migration is simply not a possibility.

- Middle elevation biota have a High, Moderate, or Low vulnerability as some degree of upslope area may exist for biota to migrate and extend their range upslope. This assumes environmental conditions and a means to migrate allow for an upslope expansion.

- Low elevation biota have a Very Low vulnerability as they have the most available land area existing upslope, and the highest potential to extend their range upslope. This assumes environmental conditions and a means to migrate allow for an upslope range expansion.

\section{Vulnerability of cold-adapted, foundation, or keystone species occupying aspen ecosystems to climate} change

- Cold-adapted species are those that have adaptive mechanisms to tolerate cold environments, and are sensitive to warm temperatures. These species are differentiated from warm-adapted species that tolerate warm to hot temperatures.

- Foundation species are those that have substantial influences on ecosystem structure and function as a consequence of their high biomass.

- Keystone species are those that exert strong effects on the structure and function of their ecosystem, despite having a low biomass.

Vulnerability is assigned based on the degree of species sensitivity to exposure of a warmer and drier climate and its ability to adapt and persist.

- A Very High vulnerability is assigned if species have a high risk of being eliminated from aspen ecosystems.

- A High, Moderate, to Low vulnerability is assigned if species are likely to be hampered to a high, moderate or low degree, but not eliminated.

- Very Low vulnerability is assigned if species are not hampered, and have a high likelihood of persisting or expanding.

\section{Sensitivity to extreme climatic events (drought, heat, flood)}

Sensitivity is the degree to which aspen ecosystems serve as species habitats are affected by changes in climate such as droughts, floods, and extreme heat.

- Very High sensitivity is assigned when higher frequencies or severities of extreme events raises the risk to greatly disrupt aspen ecosystems.

- $\quad$ A High, Moderate, or Low sensitivity is assigned when higher frequencies or severities of extreme events raise the risk to disrupt aspen ecosystems to a high, moderate, or low degree.

- Very Low sensitivity is assigned when increased frequency or severity of extreme events is unlikely to significantly affect aspen ecosystems. 
Table 1-(Continued).

\section{Intrinsic adaptive capacity to climate change}

Intrinsic adaptive capacity is the inherent ability of ecosystems to accommodate or cope with the effects of climate change.

- Very High vulnerability is assigned when adaptive mechanisms, such as slow recovery periods, low biodiversity, species ability to mitigate or adapt to climate changes are low, thus contributing to a low adaptive capacity.

- $\quad$ A High, Moderate, or Low vulnerability is assigned when recovery periods, biodiversity, species ability to mitigate and adapt to climate changes are high, moderate, or low.

- Very Low vulnerability is assigned when there are short recovery periods, high biodiversity, and a high ability of species to mitigate and adapt to climate change.

\section{Dependence on a specific hydrologic regime}

The hydrologic regime is the characteristic pattern of water flowing through an ecosystem, and is dependent on climate to determine the rate, timing, and volume in groundwater and surface water moving through the ecosystem.

- Very High vulnerability is assigned when ecosystems function within a relatively narrow hydrologic regime. For example, snow-driven aquatic ecosystems, with hydrologic processes and cold-adapted biotas like fish that are highly dependent on stream flow from snowmelt have a high vulnerability.

- High, Moderate, or Low vulnerability is assigned when ecosystems are less dependent on a narrowly functioning hydrologic regime. Biota can withstand some variability. For example, vegetation depends on moisture during the growing season but is not dependent on a specific form and can withstand annual variation or periods of drought.

- Very Low vulnerability is assigned when ecosystems are not dependent on a narrowly functioning hydrologic regime. Biota are not dependent on a specific form or timing of moisture. An example would be an ecosystem that can withstand periods of little to no moisture along with periods of elevated moisture.

\section{Potential for climate change to exacerbate effects of non-climate stressors, or vice versa}

Climate change effects of warming and drying can exacerbate or worsen non-climate stressors. For example, human water withdrawal (a potential stressor) lowers water levels in streams and lakes, and climate warming can increase evaporation, further lowering water levels.

- Very High vulnerability is assigned when there is a high probability that climate change may worsen the effects of a non-climate stressor, or that the non-climate stressor may worsen the effects of climate change.

- High, Moderate, or Low vulnerability is assigned when there is some probability that climate change may worsen the effects of a non-climate stressor, or that the non-climate stressor may worsen the effects of climate change.

- Very Low vulnerability is assigned when there is a very low probability that climate change may worsen the effects of a non-climate stressor, or that the non-climate stressor may worsen the effects of climate change.

\section{Likelihood of managing or alleviating climate change effects}

- Ecosystems have Very High vulnerability when there are no known feasible management approaches that could be employed, or the likelihood of effectiveness is very low to mitigate the effects of climate change and reduce non-climate stressors.

- Ecosystems have a High, Moderate, or Low vulnerability when feasible management approaches exist, (for example, controlled burning or coppicing to promote suckering, fencing to reduce browsing pressure on suckers), and have been shown to have a high, moderate, or low effectiveness in mitigating the effects of climate change and reducing non-climate stressors.

- Ecosystems have a Very Low vulnerability when feasible management approaches exist, (for example, controlled burning or coppicing to promote suckering, fencing to reduce browsing pressure), and have been shown to be very effective in mitigating the effects of climate change and reducing non-climate stressors. 
The assessment is intended to provide an initial literature-based synthesis on vulnerability and to provide a basic framework of information that can be updated as more becomes available. The vulnerability assessment is intended to assist in the development of climate adaptation options for aspen ecosystems and to provide reference information for forest planning and NEPA documents.

Seven criteria define different factors of vulnerability to climate change and nonclimate stressors. Vulnerability is scored Very Low, Low, Moderate, High, or Very High for each of the seven criteria. When several vulnerability indicators are included in one criterion, the score is evenly weighted, and individual sections describe the different characteristics of those vulnerability criteria. The final vulnerability ranking is determined by averaging the 7 criteria scores into a final score ranging from 1 to 5 (Very Low=1, Low=2, Moderate=3, High=4 and Very High=5) (table A1). 


\section{Climate in the Uinta-Wasatch-Cache and Ashley National Forests, Utah}

\section{Observed Climate}

The Uinta-Wasatch-Cache and Ashley NFs encompass some of the wettest and coolest terrain in the State of Utah (fig. 4). That, combined with high elevation and cooler temperatures, has historically permitted large snowpacks to accumulate in winter and melt in the spring and summer, acting as Utah's largest reservoir, or storage mechanism for water. This snowmelt is a major water source for aspen ecosystems.
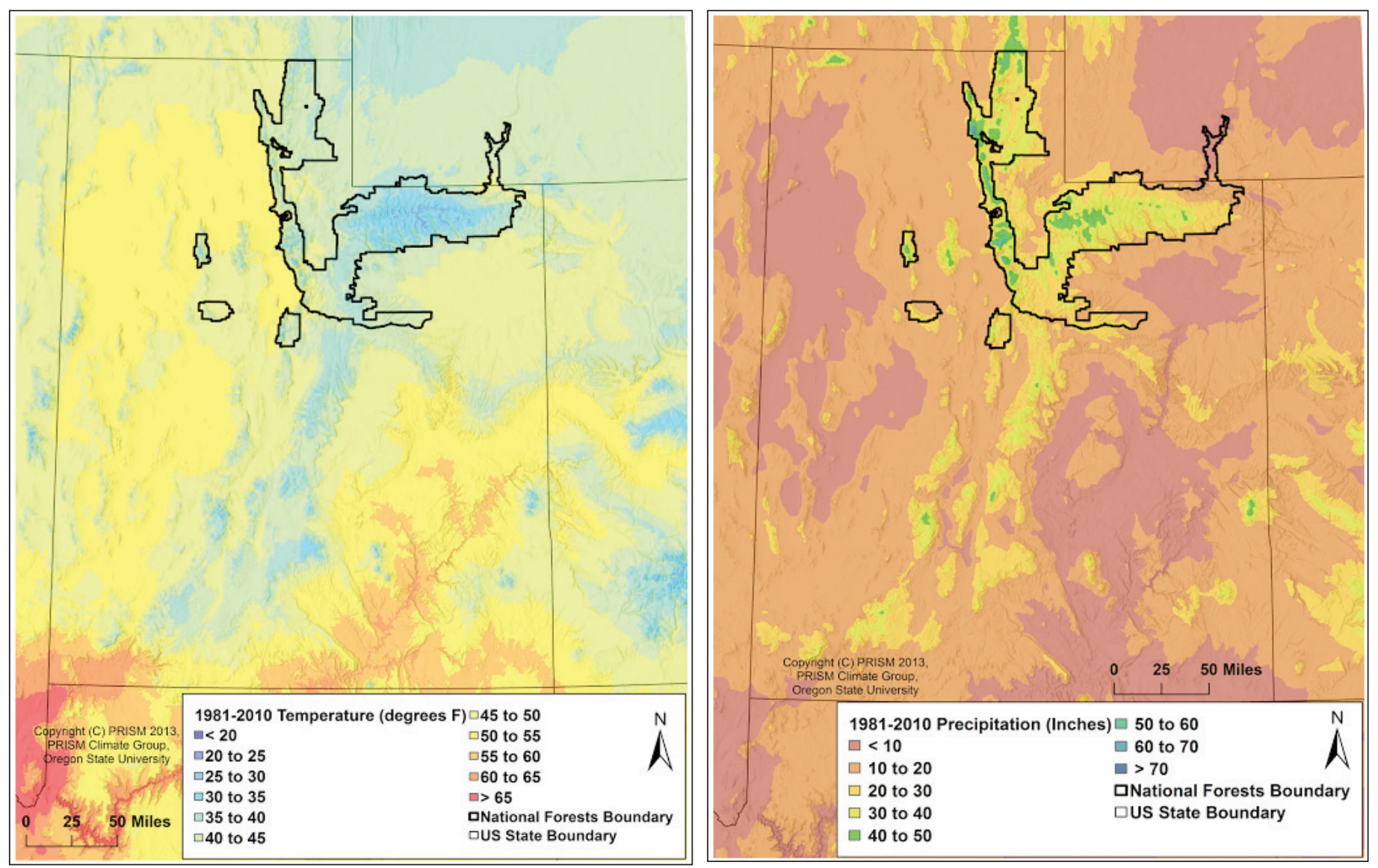

Figure 4-Annual Mean Temperature ( ${ }^{\circ} \mathrm{F}$ ) (left) and Total Annual Precipitation (inches) (right) for 1981-2010 over the State of Utah based on observed climate and spatially interpolated using the Parameter-elevation Relationships on Independent Slopes (PRISM) model. The resolution is at 800 meters (http://prism.oregonstate.edu). Hillshade data credit: Esri, USGS, NGA, NASA, CGIAR, N Robinson, NCEAS, NLS, OS, NMA, Geodatastyrelsen, Rijkswaterstaat, GSA, Geoland, FEMA, Intermap, and the GIS user community.)

\section{Temperature}

The State of Utah's Climate Division 5 (fig. 5), encompasses most of the UintaWasatch-Cache and Ashley NFs as well as adjacent lands outside of the forest boundary in northeastern Utah. We use the Climate Division 5 boundary to present the historical climate (temperature, precipitation) and climate projections for the mid-century. Temperatures have increased in Climate Division 5 as well as throughout Utah and the western United States over the past century and most rapidly since 1970. 


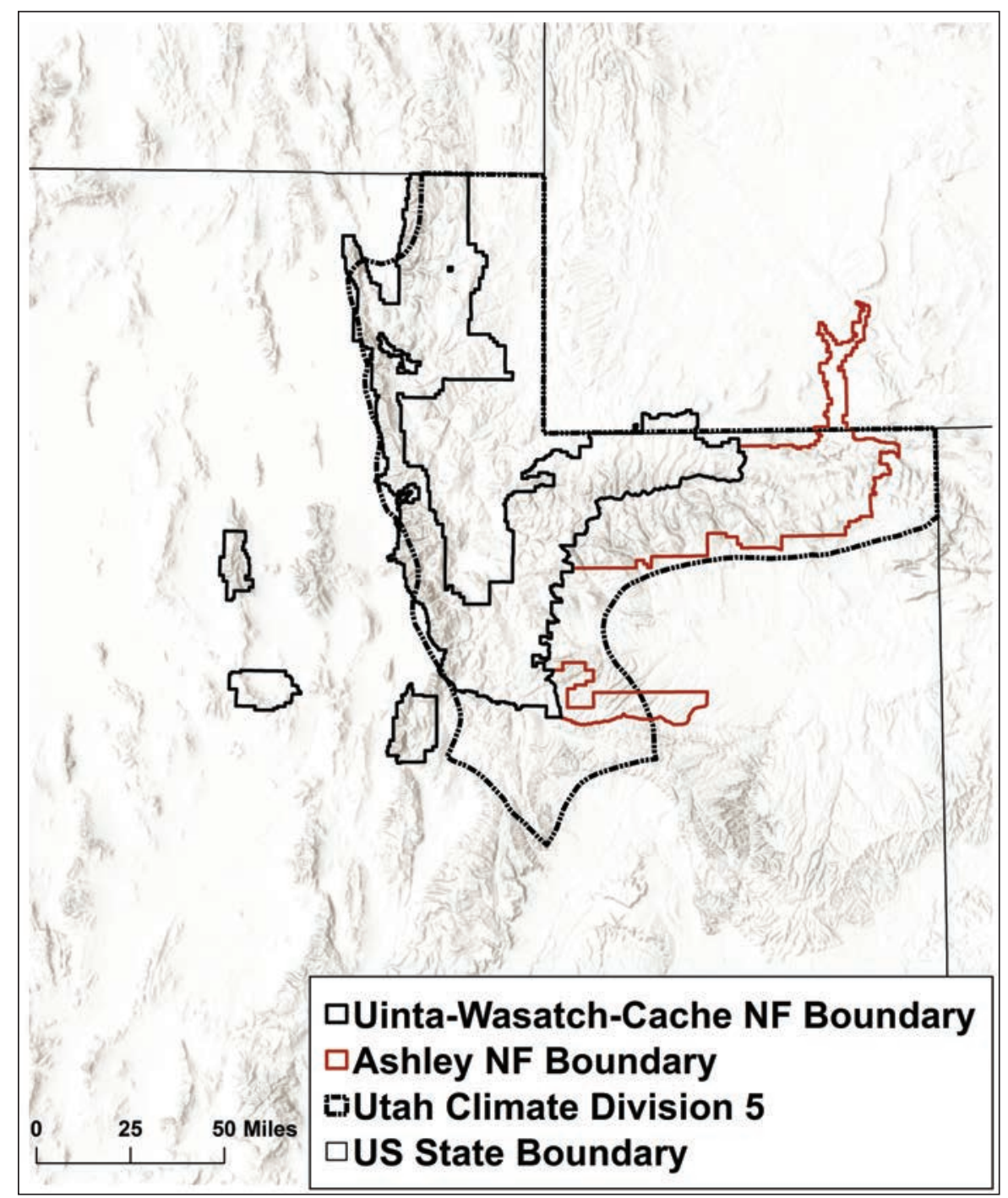

Figure 5-Utah's Climate Division 5 overlaid on the Uinta-Wasatch-Cache and Ashley National Forest Boundaries (http://www.ncdc.noaa.gov/monitoring-references/maps/us-climate-divisions. php). Climate Division 5 encompasses the majority of the Uinta-Wasatch-Cache and Ashley NFs. Hillshade data credit: Esri, USGS, NGA, NASA, CGIAR, N Robinson, NCEAS, NLS, OS, NMA, Geodatastyrelsen, Rijkswaterstaat, GSA, Geoland, FEMA, Intermap and the GIS user community.)

The average annual temperature in Climate Division 5 has risen over the last century with a statistically significant trend of $0.2^{\circ} \mathrm{F}$ per decade since 1900 , and $0.5^{\circ} \mathrm{F}$ per decade since 1970 (Mann-Kendal $p$ value $<0.01$ ) (fig. 6).

\section{Precipitation}

The precipitation record in Utah and Climate Division 5 is dominated by large interannual and decadal variability. No long-term trends have yet been observed in seasonal or annual precipitation in northern Utah (fig. 7).

\section{Snow}

Studies of the western United States have indicated a tendency towards decreasing snow water equivalent (SWE) and earlier snowmelt peak and runoff, most notably in coastal and lower elevation areas (Mote 2006; Mote et al. 2005; Regonda et al. 2005). 


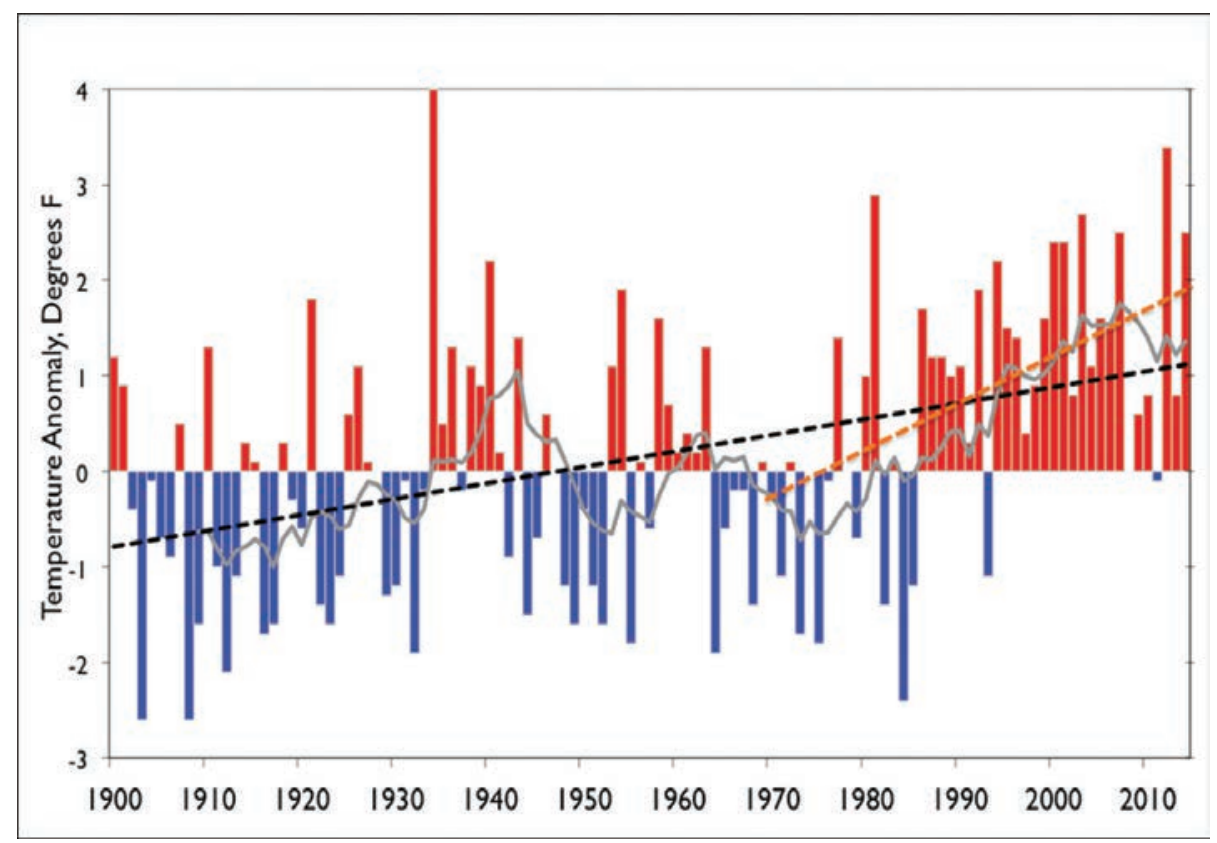

Figure 6-Utah Climate Division 5 temperature anomaly of the mean annual temperature $\left({ }^{\circ} \mathrm{F}\right)$, 1900-2014. Annual departures are relative to the 1901-2000 average. The dashed black line and orange lines are the 1900-2014 and 1970-2014 linear trends, respectively. Both upward trends are statistically significant. The average annual temperature in Climate Division 5 has risen over the last century with a statistically significant trend of $0.2^{\circ} \mathrm{F}$ per decade since 1900 , and $0.5^{\circ} \mathrm{F}$ per decade since 1970 (Mann-Kendal $p$ value $<0.01$ ). The gray line is the 10 -year running average. For Utah, Climate Division 5 encompasses the majority of the Uinta-Wasatch-Cache and Ashley National Forests (Source: NOAA-NCDC, http://www.ncdc.noaa.gov/cag/).

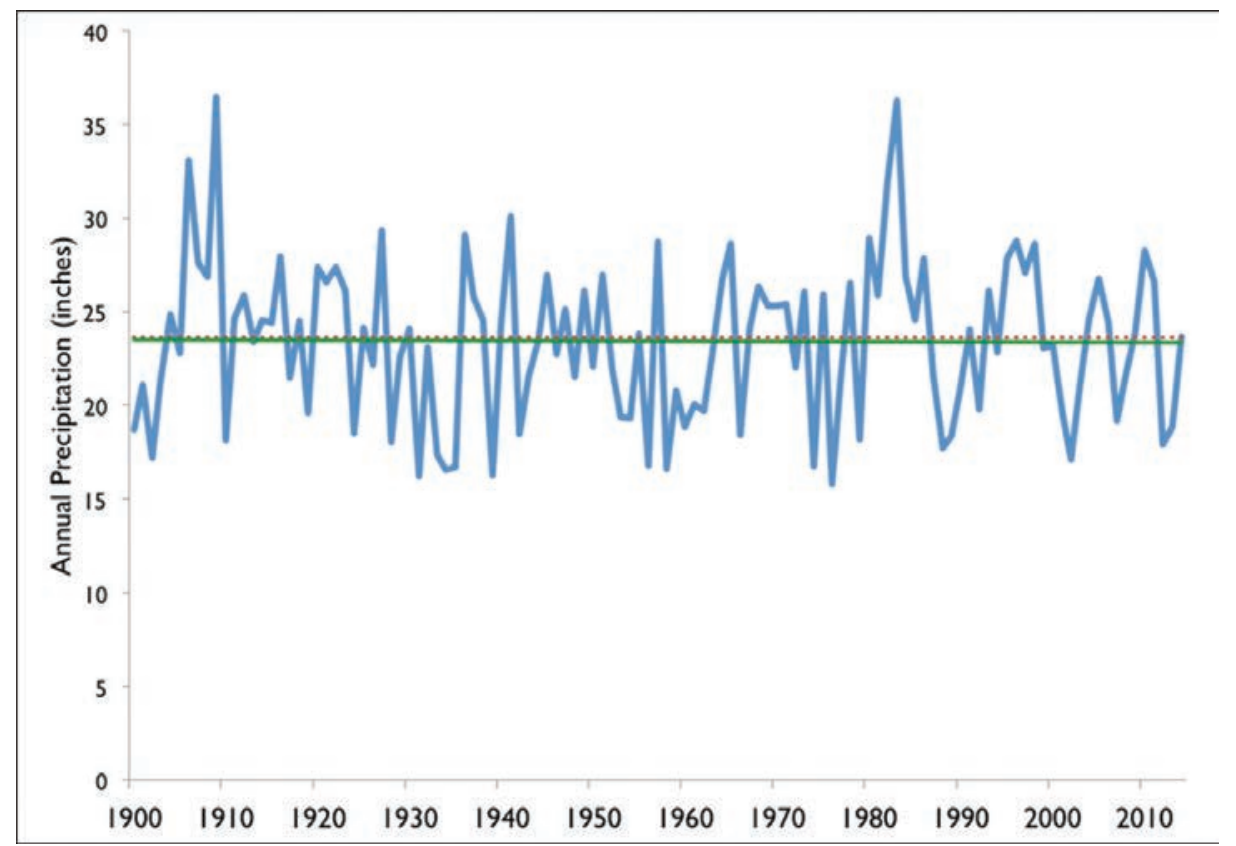

Figure 7-Utah Climate Division 5 average annual precipitation (inches), 1900-2014. The dashed red line is the 1901-2000 average, and the green line is the 1900-2014 linear trend, both of which shows no trend (source: NOAA-NCDC, http://www.ncdc.noaa.gov/cag/). 
Warming temperatures have led to more winter precipitation falling as rain instead of snow in Utah. Gillies et al. (2012) documented a 9 percent decrease in the proportion of winter precipitation (January-March) falling as snow from 1950 to 2010 in Utah, a combined result from a significant increase in rainfall and a minor decrease in snowfall. They also reported that a decrease in snow depth across Utah, accompanied by consistent decreases in snow cover and decreases in surface albedo. Julander and Clayton (2014) identify 19 ongoing reference snow course sites across Utah that they deemed appropriate for long-term SWE studies because they are not compromised by site characteristics, most notably vegetation encroachment. None of these snow courses show significant increasing trends in April 1 SWE. Only 16 percent (3 of the 19) reference sites in southcentral and southeastern Utah show statistically significant downward trends in April 1 SWE over their respective periods of record varying from 60 to 85 years.

\section{Projected Changes in Climate}

Global Climate Models (GCMs) are quantitative tools used to explore the range of possible future climate conditions. Global climate models simulate the complex interactions among the land, oceans, and atmosphere and are based on fundamental scientific principals using advanced mathematics in computationally intensive simulations. These climate model outputs have a range of projections from different trajectories of future greenhouse gas concentrations. Representative Concentration Pathways (RCPs) are 4 greenhouse gas (GHG) concentration trajectories over the $21^{\text {st }}$ century that are used by climate models in the 5th assessment report of the Intergovernmental Panel on Climate Change (IPCC 2014).

The four pathways are RCP 2.6, RCP 4.5, RCP 6 , and RCP 8.5. The first pathway has the lowest forcing (radiative forcing is a cumulative measure of human emissions of greenhouse gases) of RCP 2.6, and assumes that global annual GHG emissions peak between 2010-2020 and then decline. Greenhouse gas emissions in RCP 4.5 peak around the year 2040 and then decline. In RCP 6, GHG emissions peak around 2080 and then decline. The largest forcing occurs with RCP 8.5, where emissions continue to rise throughout the 21 st century.

The Coupled Model Intercomparison Project phase 5 (CMIP5) uses the four standardized greenhouse gas concentration scenarios or RCPs. This project was established by the Working Group on Coupled Modeling (WGCM) to provide a standard experimental protocol for studying the output of coupled atmosphere-ocean general circulation models (AOGMCs). This project supports diagnosis, validation, intercomparison, documentation, and data access for the more than 20 international climate modeling groups.

The worldwide climate modeling centers comprise a total of 62 GCM models, sometimes having multiple runs of the same model (see Appendix $\mathrm{C}$ for list of models). While each center uses the same fundamental physical principles to drive their models, some climate processes are represented differently in each model. Future simulations of temperature, and especially precipitations, vary among different models attributed to different modeling methods and ways of incorporating climate processes in them. 
Although GCMs have advanced significantly in the past several decades to include additional processes and higher spatial resolution, even the highest resolution existing GCMs are not able to adequately represent the steep mountainous terrain of the Uinta Mountains and Wasatch Range. A variety of downscaling methods have been developed to translate GCM output to scales capturing the terrain variability relevant to resource managers. In this study, we utilized the Bias-Correction Spatial Disaggregation (BCSD) method (http://gdo-dcp.ucllnl.org) to represent the mountainous terrain of the Uinta Mountains and Wasatch Range.

Downscaled temperature and precipitation climate projections in Utah's Climate Division 5 for the middle-low forcing climate scenario RCP 4.5 show an average of $3.7^{\circ} \mathrm{F}$ increase in annual temperature, and on average, a small annual precipitation increase by mid-century compared to a 1981-2010 baseline (table 2, figs. 8 and 9) (downscaling technique by Maurer et al. [2007]). Nighttime low temperatures are expected to rise as much as daytime high temperatures. Projections indicate that summer temperatures may warm somewhat more than winter and spring (fig. 8).

While there is a high degree of confidence that temperatures in all seasons will continue to increase, there is less confidence with projected changes in precipitation. The RCP 4.5 projections on average indicate about a 4 percent increase in annual precipitation, but about one-third of the 71 model runs indicate decreases in future mean annual precipitation. There is higher model run agreement that winters will be wetter, with 75 percent of model runs indicating an increase in average winter precipitation.

In fig. 10 , the $10^{\text {th }}$ percentile $\left(+2.2^{\circ} \mathrm{F}\right)$ and $90^{\text {th }}$ percentile $\left(+5.8^{\circ} \mathrm{F}\right)$ of the projected temperature increases were uniformly added to the PRISM 1981-2010 observed mean temperatures. Under the $90^{\text {th }}$ percentile warming, annual mean temperatures at upper elevations in the Uinta Mountains $\left(+5.8^{\circ} \mathrm{F}\right)$ are raised to just below or above freezing levels, while the majority of upper elevation areas in the Wasatch Range are raised above freezing.

Table 2-Projected changes in mean annual temperature and precipitation from 1981-2010 to 2035-2064 for northeastern Utah Climate Division 5 under RCP 4.5.

\begin{tabular}{|c|c|c|c|c|}
\hline Projected changes by $2035-2064^{a}$ & Mean & 10 th $^{b}$ & 50 th $^{\mathrm{c}}$ & 90th ${ }^{\mathrm{d}}$ \\
\hline Change in mean annual temperature $\left({ }^{\circ} \mathrm{F}\right)$ & 3.7 & 2.2 & 3.7 & 4.9 \\
\hline Change in mean annual precipitation (\%) & 4.2 & -5.8 & 3.2 & 15.1 \\
\hline
\end{tabular}

a Projections are based on 71 model runs from 1/8 CMIP5 BCSD (bias-correction and spatial disaggregation) for the Representative Concentration Pathway (RCP) 4.5. Accessed from: http://gdo-dcp.ucllnl.org/downscaled_cmip_projections/dcplnterface.html

b The $10^{\text {th }}$ percentile value has 10 percent of model outputs that are less than or equal to the value, while 90 percent are above the value.

c The $50^{\text {th }}$ percentile value has 50 percent of the model outputs less than or equal to the value, while 50 percent is above the value.

d The $90^{\text {th }}$ percentile value has 90 percent of the model outputs less than or equal to the value, while 10 percent is above the value. 


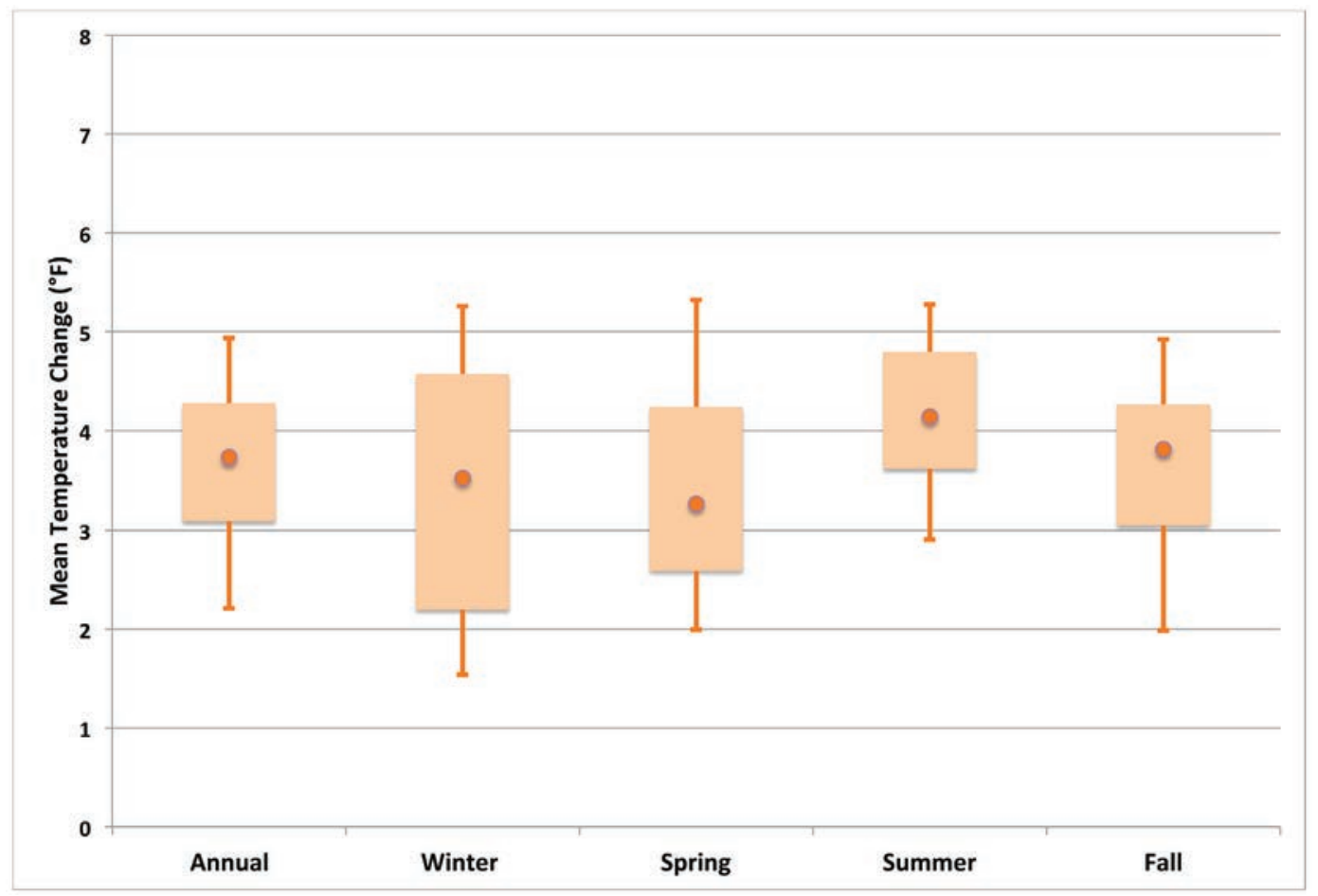

Figure 8-Annual and seasonal projected change in temperature for Climate Division 5 2035-2064 relative to 1981-2010 for 71 model runs from the RCP 4.5 of the Climate Model Intercomparison Project phase 5 (CMIP5). Dots represent the average change, while the whiskers represent the 10th and 90th percentiles, and the boxes represent the 25th and 75th percentiles of the 71 model runs. See Appendix A for projections of RCP 2.6, RCP 6.0, and RCP 8.5 (Reclamation 2014).

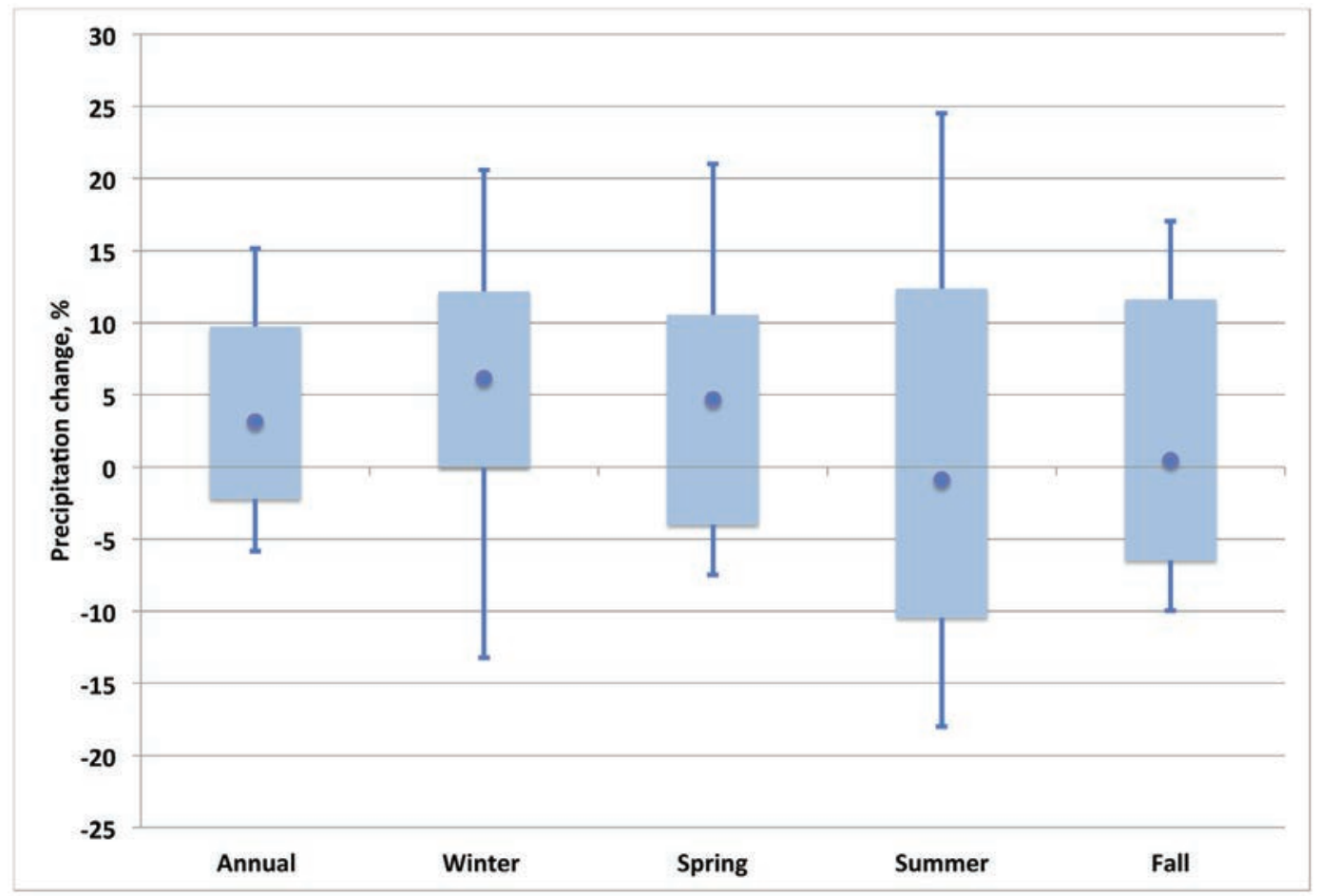

Figure 9-Annual and seasonal projected change in precipitation for 2035-2064 relative to 1981-2010 from 71 model runs from the RCP 4.5 of the Climate Model Intercomparison Project phase 5 (CMIP5 Appendix D). Dots represent the average change, while the whiskers represent the 10th and 90th percentiles, and the boxes represent the 25th and 75th percentiles of all model runs. See Appendix B for projections of RCP 2.6, RCP 6.0, and RCP 8.5 (Reclamation 2014). 


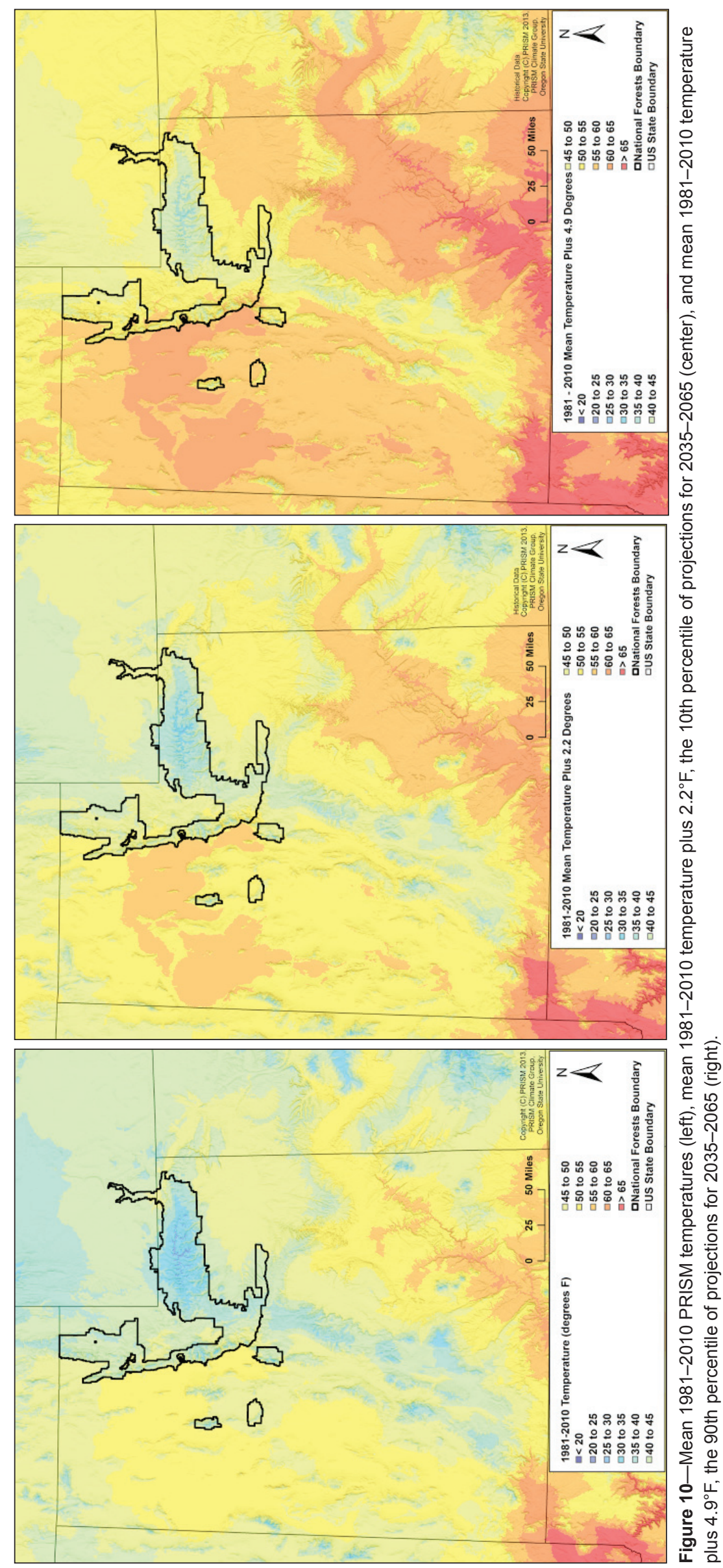




\section{Projected Trends for Snow}

As temperatures rise, more rainfall and less snow is expected in the Uinta Mountains and Wasatch Range (fig. 11). Klos et al. (2014) projected that by mid-century, a large portion of the Wasatch Range will receive more than 50 percent of December to February precipitation in the form of rain. Most of the Uinta Mountains have more than 90 percent of precipitation falling as snow in both the historic and mid-century 2035 to 2065 time periods. The decrease in the amount of moisture received as snow would result in less snowpack and drier soil moisture during the growing season.

Warmer temperatures, in the absence of changes in precipitation, are expected to lead to earlier runoff, and average annual runoff volume will decrease due to increases in evapotranspiration. A recent study in the Wasatch and western Uinta Mountains has modeled a shift in timing of the center of runoff, the date when half of the water year runoff has occurred, by approximately 3 days earlier per $1{ }^{\circ} \mathrm{F}$ warming. In the same
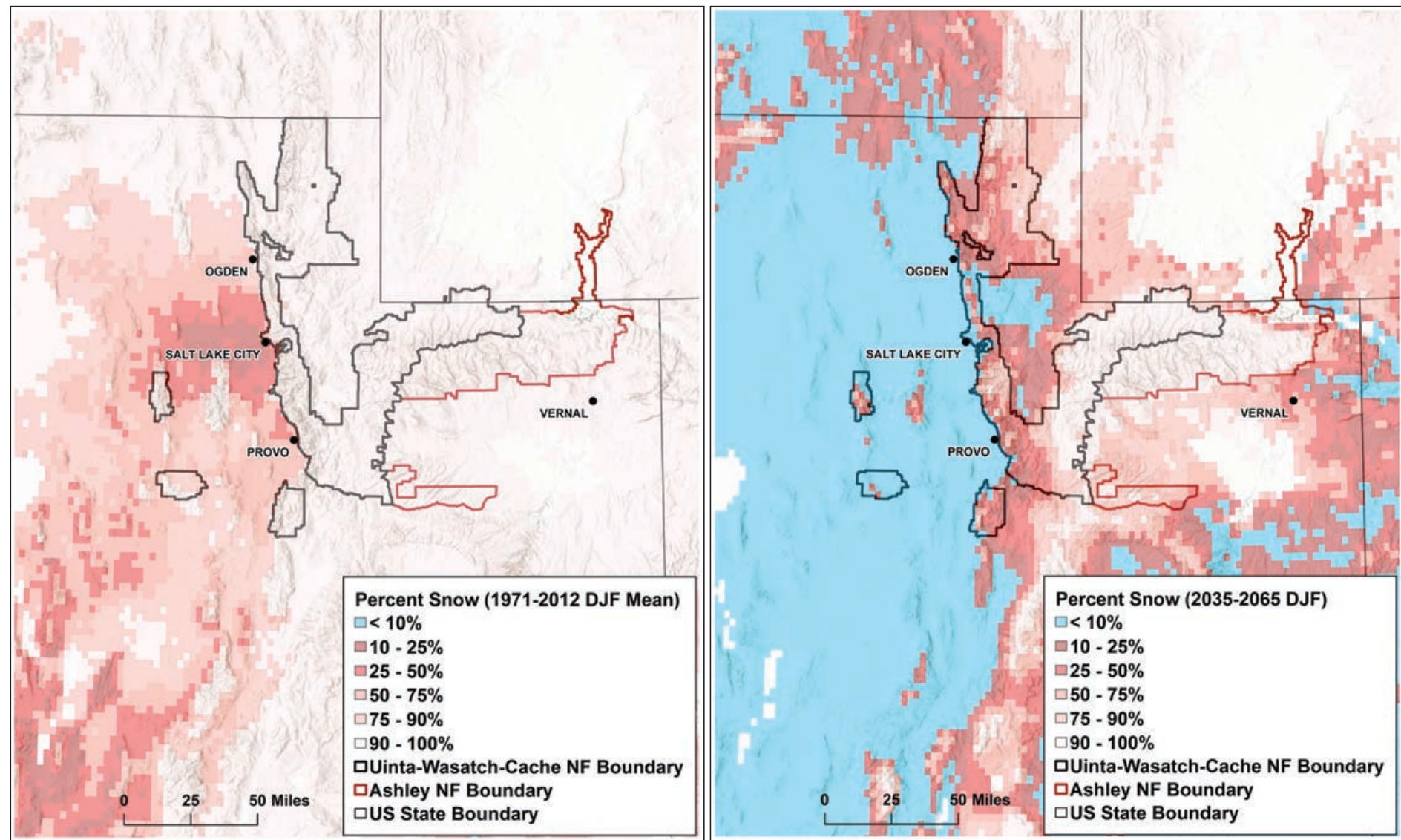

Figure 11-The percent of total precipitation received as snow mean of the months of December, January and February. Modeled for historic (19792012) (left), and mid-century (2035 to 2065) (right) using the high emissions scenario (RCP8.5) and averaged over 21 CMIP5 climate models (Klos and others 2014). (Note: Areas in light grey to white in southwestern Wyoming are where precipitation was excluded from model runs since the amounts were below a minimum threshold.) Hillshade background from: Esri. Their sources are: UGSG, NGA NASA, CGIAR, N Robinson, NCEAS, NLS, OS, NMA, Geodatastyrelsen, Rijkswaterstaat GSA, Geoland, FEMA, Intermap, and the GIS User Community. Downloaded from: http://www.arcgis.com/home/item. html?id=9c5370d0b54f4de1b48a3792d7377ff2. 
study, the average modeled decrease in annual volume was approximately 4 percent per $1{ }^{\circ} \mathrm{F}$ (Bardsley et al. 2013). Changes in runoff timing are expected regardless of potential changes in future precipitation and have implications to ecosystems and water management, while changes in annual volume caused by increasing temperatures could be offset by increasing precipitation.

\section{Extreme Events}

Relatively infrequent extreme events often exert a disproportionate impact on species and ecosystems. Recent droughts during the 1930s, 1950s, late 1970s, late 1980s, and 2000s have been much less severe or persistent than many droughts in previous centuries. Prolonged drought periods lasting several decades, also called mega droughts, have been recorded from tree rings during the 1200s, late 1400s, and 1800s (Bekker et al. 2014; DeRose et al. 2015; MacDonald and Tingstad 2007). MacDonald and Tingstad (2007) reported 19 episodes of single-year or multi-year extreme droughts over the last 500 years.

Severe and extreme intensity droughts were recurrent events in the Uinta Mountain region, averaging 2 to 5 times per century since the 1400s (MacDonald and Tingstad 2007). Bekker et al. (2014) found that most Wasatch Range droughts were during the 1400s and 1500s and the 1700s. The 1800s had fewer but the longest duration droughts. Three droughts have been recorded during the 1930s, the late 1950s, and the early 2000s. In both the Uinta Mountains and Wasatch Range, the 1900s was a relatively wet period compared to previous centuries, with the least recurrence of drought (Bekker et al. 2014; MacDonald and Tingstad 2007).

The recent drought events in the Wasatch Range and Uinta Mountains have been correlated with periods of decreased eastern Pacific sea surface temperatures (Kunkel et al. 2013; MacDonald and Tingstad 2007). Recent drought as measured by the Palmer Drought Severity Index has increased in Utah's Climate Division 5 since 1970, due mostly to increasing temperatures driving more rapid drying.

There is high climate model agreement that more extreme heat will occur by the mid-2 $1^{\text {st }}$ century. Kunkel et al. (2013) projections show an increase of 5 to 10 days per year where temperatures exceed $95^{\circ} \mathrm{F}$ in northern Utah. The largest number of projected extreme heat days is in lower elevations around the Uinta Mountains and Wasatch Range (see figure 23 in Kunkel et al. 2013). Multiple-day periods of extreme high temperatures are expected to increase as the climate warms (Lukas et al. 2014). Extreme heat events have been increasing over the past 30 years, but the number of events occurring from 2003 to 2012 did not exceed the amount experienced during the 1930s (Lukas et al. 2014). 
Fewer storm events with more precipitation per event have been happening in Utah since the mid-20 $0^{\text {th }}$ century (Gillies et al. 2012). Bekker et al. (2014) found that extremely wet periods, or pluvials, during the $17^{\text {th }}$ century were wetter than the early $1900 \mathrm{~s}$ pluvial, but was dwarfed in comparison to the 1980s flood event in the Wasatch Front. A climate reconstruction for the Bear River in the Wasatch Range based on tree ring records by DeRose et al. (2015) found that the latter half of the $20^{\text {th }}$ century was the second wettest in 1,200 years. High flows in the Uinta Mountains were also recorded from the late $16^{\text {th }}$ to mid- $17^{\text {th }}$ centuries and the first half of the $20^{\text {th }}$ century (Carson and Munroe 2005). Extreme peak flow events have been increasing in the Uinta Mountains since the 1960s as a result of high precipitation and cold winter and early spring temperatures that preserve snowpack (Carson 2007). Kunkel et al. (2013) report no observed increase in days with precipitation exceeding 1 inch from 1980 to 2000 on the southwestern United States, but projections show the number of days with more than 1 inch of precipitation to increase by the end of the $21^{\text {st }}$ century for northern Utah. Extreme precipitation events and extreme heat are projected to increase for the region by the end of the $21^{\text {st }}$ century across the United States, while consecutive dry days are projected to also increase (Kunkel et al. 2013; Wuebbles et al. 2014). These projections would tend to lead to enhanced risk of both flood and drought in a warmer future climate. 


\section{Vulnerability of Uinta-Wasatch-Cache and Ashley National Forests Aspen Ecosystems to Climate Change}

\section{Range Shift Capacity}

Summary: A moderate vulnerability is assigned as aspen have some capacity for range shifts, specifically:

- Aspen is likely to remain several hundred miles north of its southern range limit, which currently extends through Arizona and Mexico. Low vulnerability is assigned.

- Upslope migration is limited, especially in the Wasatch Range. Migration may have variable success as conifer competition, suitable soils, and microsite conditions are needed to support the biota. High vulnerability is assigned.

Information confidence:

- The potential for aspen to remain well north of its southern range limit is supported by three studies, two of which are bioclimatic modeling studies.

- The potential for aspen to shift ranges, given favorable conditions, is supported by 22 studies.

\section{Southern Range Limit Proximity}

Aspen is the most widely distributed native tree species in North America. Aspen covers mountainous landscapes from Alaska, extending south through Arizona; a few pockets grow at its southern range limit in central Mexico (Little 1971). Aspen extends from the Pacific Northwest and California, throughout the Rocky Mountains to the upper Midwest and northeastern United States into Canada (Little 1971). Aspen on the Uinta Mountains and Wasatch Range is several hundred miles north of the southern range limit. Under a changing climate, suitable habitat for aspen is projected to remain extended south through Arizona during the mid-21st century (Gray and Hamann 2013; Rehfeldt et al. 2006), although fewer models project aspen presence in Arizona for the 2071 to 2100 time period (Gray and Hamann 2013). Aspen is projected to remain present in the Uinta Mountains and Wasatch Range through the mid-21st century, and it is likely to remain at least 125 miles north of the southern range limit, so vulnerability of this criterion is low.

\section{Elevation Range Shift Capacity}

Aspen stands in the Uinta Mountains and Wasatch Range cover the montane and subalpine life zones. The montane life zone extends from about 8,000 to 10,000 feet elevation. The subalpine life zone extends from about 10,000 feet elevation to tree line, which is about 11,500 feet in the Wasatch and Uinta Mountain Ranges. In the Wasatch Range, aspen spans elevations from about 4,300 to 11,500 feet, with very few aspen stands occurring below 6,000 feet or above 10,000 feet (fig. 12). In the Uinta Mountains, aspen stands span elevations from 5,800 to 12,400 feet, with very few below 7,000 feet or above 11,000 feet (fig. 13). The potential upslope expansion of aspen ecosystems in the subalpine zone is limited in areas where aspen stands are found close to peak tops. 


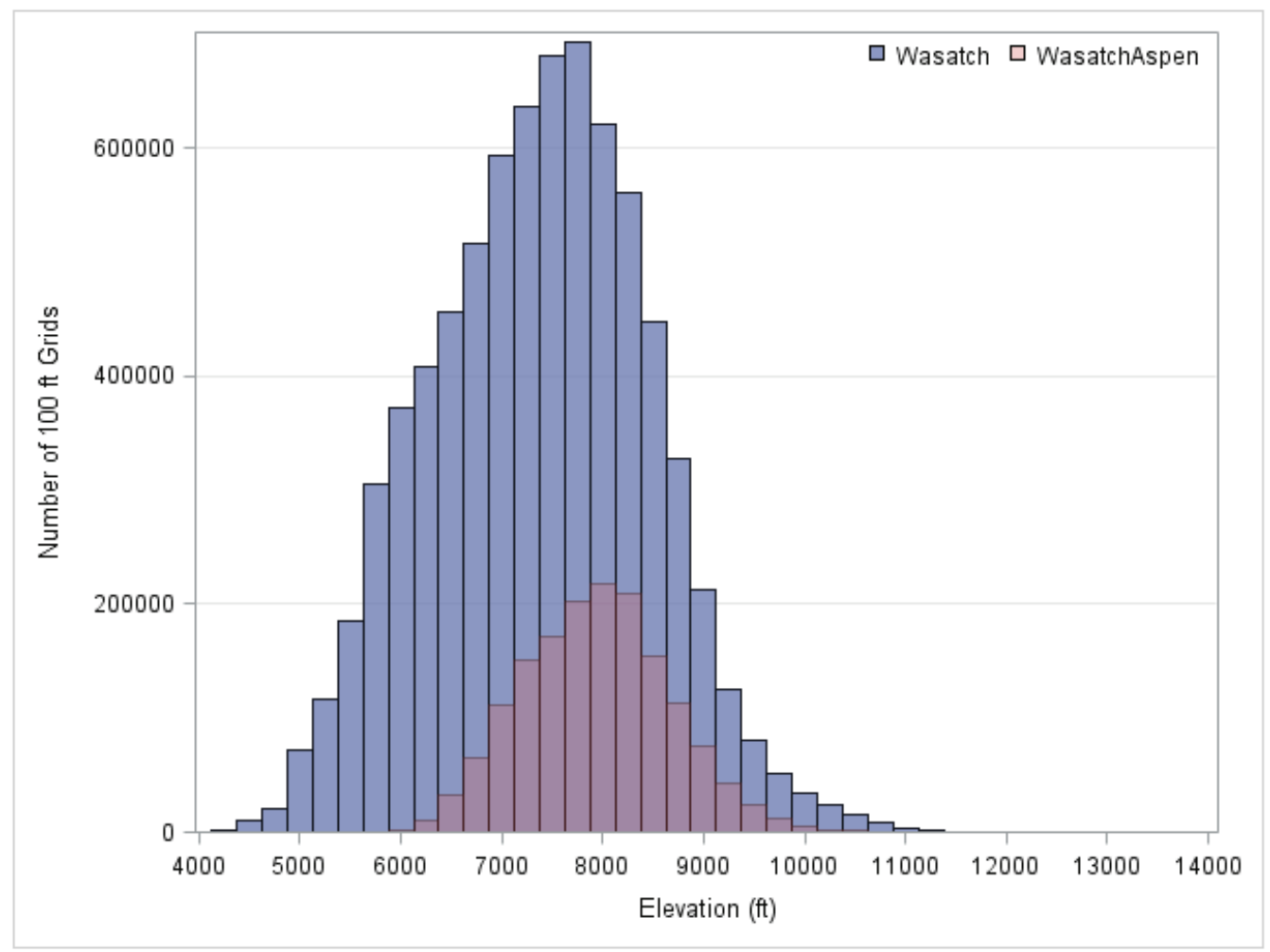

Figure 12-Wasatch Range aspen elevation distribution (purple), and total Wasatch Range land area elevation distribution (blue). The number of approximately $100 \mathrm{ft}^{2}$ or $30 \mathrm{~m}^{2}$ grid cells were calculated from the LANDFIRE data set that were classified aspen or aspen conifer mixed forests (USDA 2013a), and the elevation distributions were calculated from a Digital Elevation Model (USGS 2014).

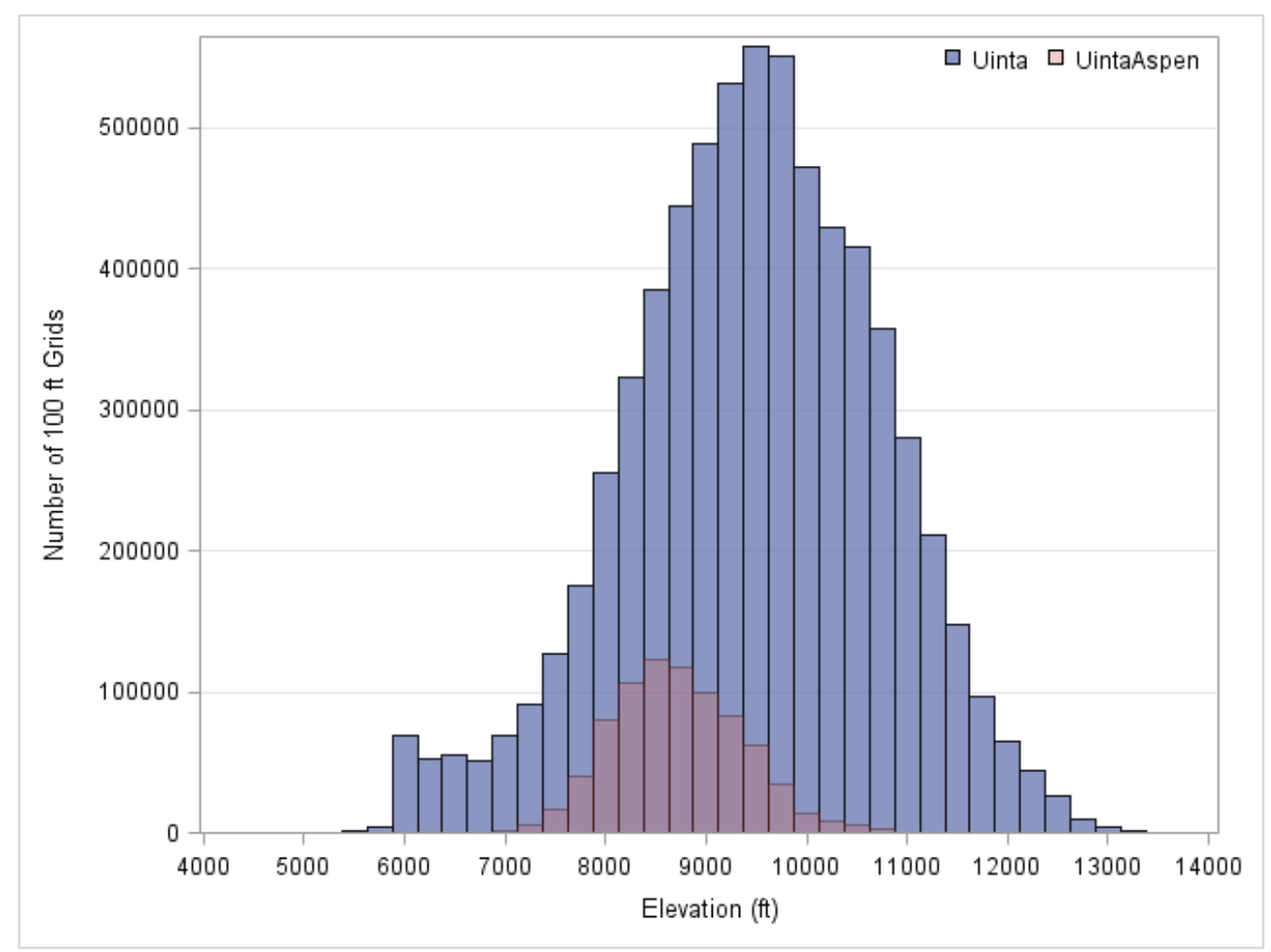

Figure 13-Uinta Mountains aspen elevation distribution (purple), and total Uinta Mountains land area elevation distribution (blue). The number of approximately $100 \mathrm{ft}^{2}$ or $30 \mathrm{~m}^{2}$ grid cells were calculated from the LANDFIRE data set that were classified aspen or aspen conifer mixed forests (USDA 2013a), and the elevation distributions were calculated from a Digital Elevation Model (USGS 2014). 
The Wasatch Range has peak elevations extending to about 11,000 feet, offering limited upslope area for aspen tree migration. The extent of potential habitat that would support aspen is projected to shrink as a result of climate change, especially in the Wasatch Range, and less land area is available at higher elevations for aspen to exist (fig. 12). The Uinta Mountains have area above 11,500 feet extending to about 13,000 feet elevation, which could offer some potential area for upslope expansion, assuming environmental conditions such as soils are suitable to support aspen.

In seral aspen types, aspen range movement can be inhibited by the presence or encroachment of conifers. Seral or mixed aspen-conifer stands are often successional to conifers; aspen are outcompeted and eventually replaced by more shade-tolerant conifers (Calder et al. 2011; Calder and St. Clair 2012; Shepperd et al. 2001). Without disturbances such as fire, conifer insect pathogens, or disease, the conifers frequently replace aspen (Shinneman et al. 2013), resulting in a local contraction of aspen coverage. Conversely, aspen may expand following fires, which may promote aspen dominance in the local landscape (Kulakowski et al. 2013b) if climate and herbivory rates are suitable for aspen persistence.

The persistent aspen type can exist in pure stands with dense patches of varying size within a matrix of other vegetation types (Cottam 1954; Shinneman et al. 2013). These isolated pure stands can be relatively stable over time because these aspen stands appear unaffected by fire and conifer succession (Smith and Smith 2005). Such aspen types may not contract if microclimate conditions are stable, but they also may not expand into the surrounding vegetation matrix, as they are not shade tolerant.

Bioclimatic models project that aspen climate profiles, or climates that would support aspen, will contract from lower elevations and expand upslope (Rehfeldt et al. 2006, 2009, 2015) (fig. 14). The aspen bioclimate projections use climate variables, including mean annual temperature and precipitation, warmest and coldest month mean temperature, seasonal precipitation, growing degree days, frost free period, dryness indexes, and first and last freezing dates. Current aspen distribution modeled by Rehfeldt et al. (2009) were in close agreement with aspen distribution defined by Little's (1971) range map.

Bioclimatic models provide a means to spatially define areas that are likely to have a climate that supports or does not support a particular tree species, such as aspen. A caveat on bioclimatic model projections is that the potential for aspen trees to shift ranges is dependent on other environmental conditions as well. For example, suitable soil conditions, topography, and disturbance, as well as the absence of vegetation competition, and the ability or inability of aspen to migrate by natural seeding or suckering, are factors that need consideration as well. These different factors, as well as climate, contribute to govern the establishment and mortality of aspen (Kulakowski et al. 2013a). Aspen extent expansions as well as contractions have been documented in many areas of the western United States since Euro-American settlement (Kashian et al. 2007; Kulakowski et al. 2013a, 2006; Zier and Baker 2006). 


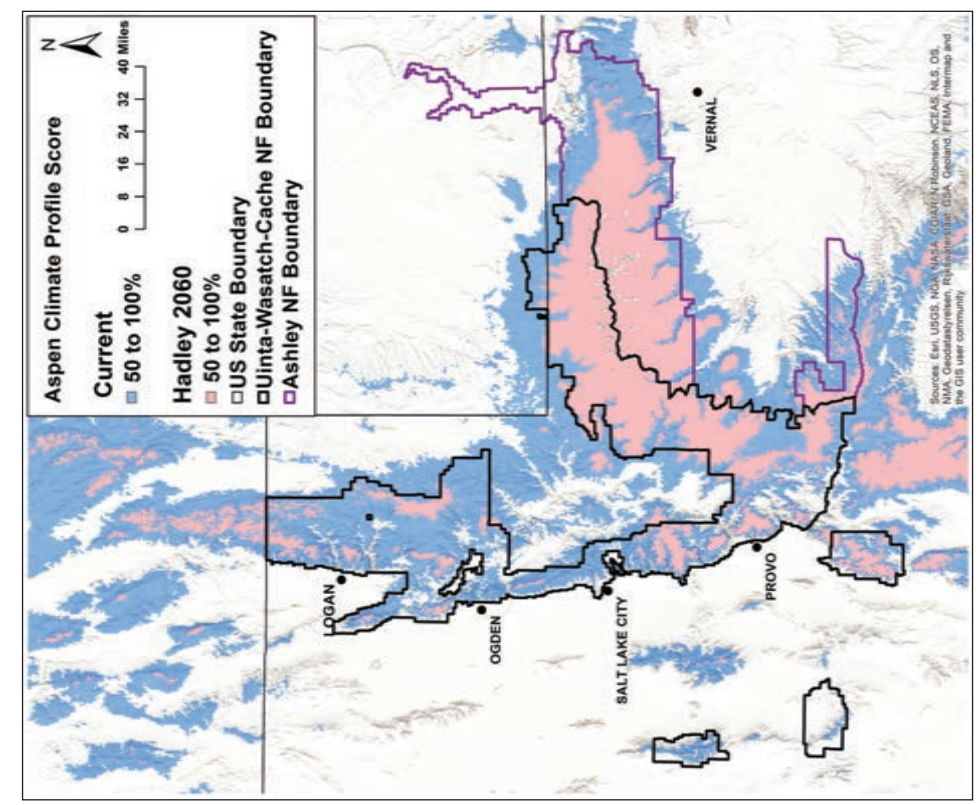

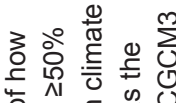

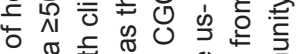

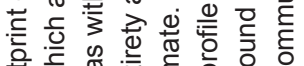

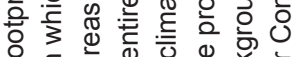

는

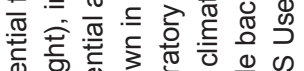

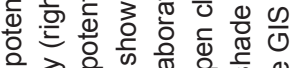

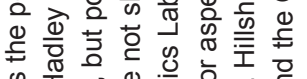

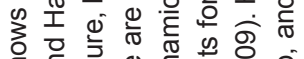

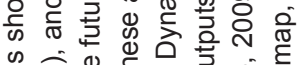

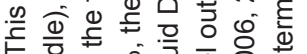

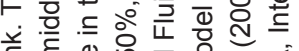

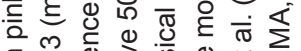

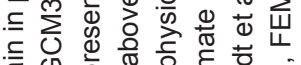
产

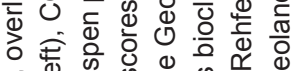

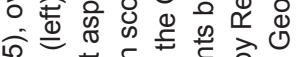

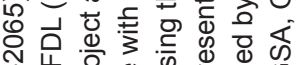

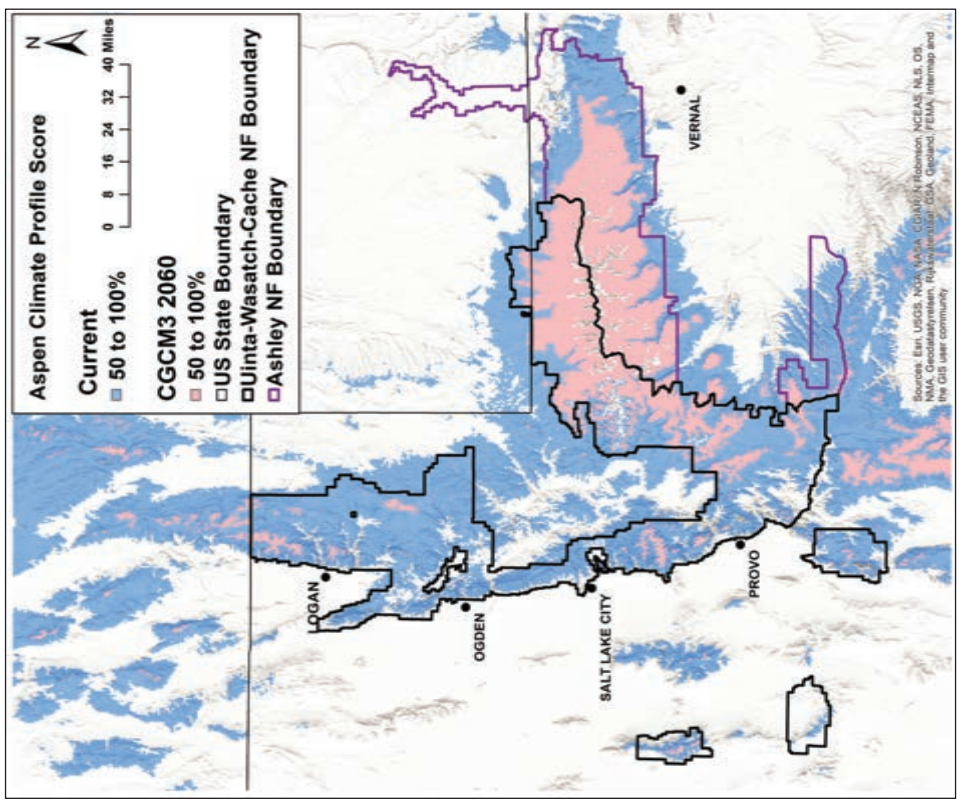

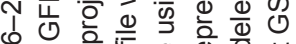

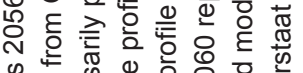

品

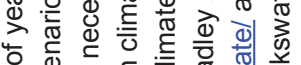

通

ब.

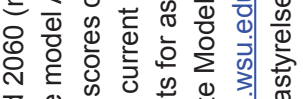

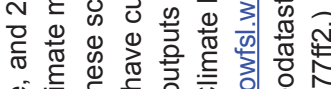

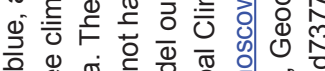

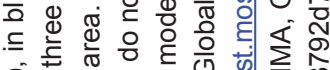

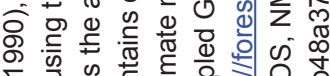
I

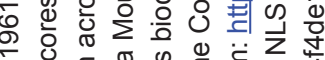

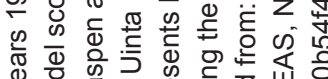
巴。

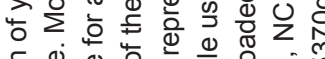

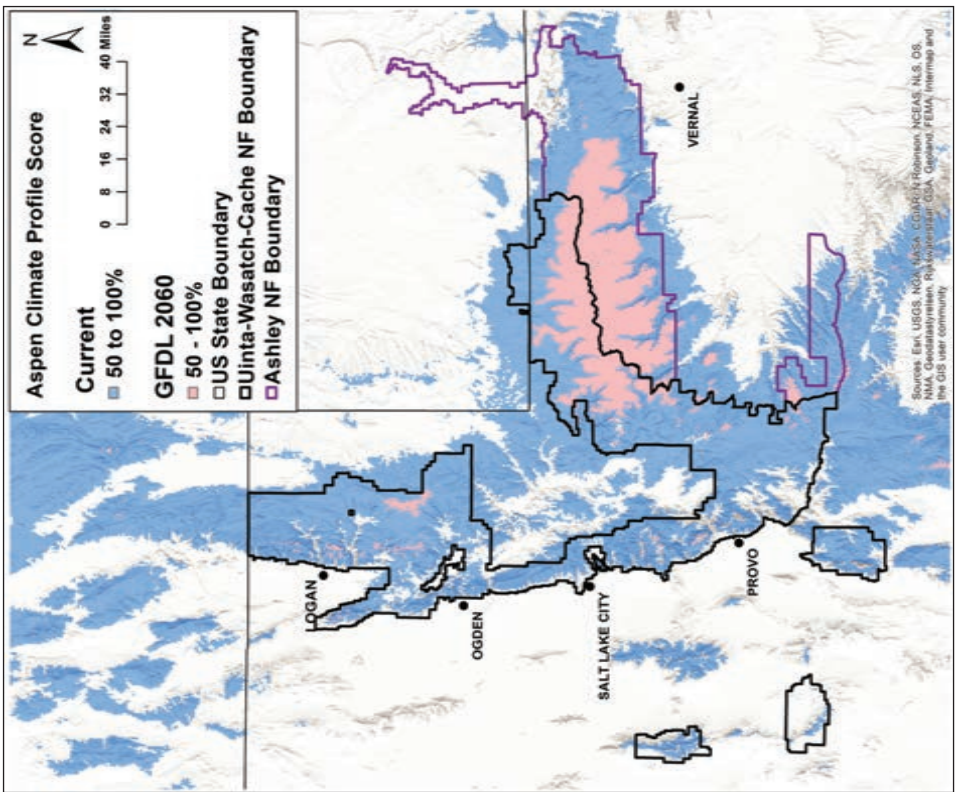
ॠ ह 등 흔

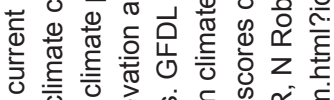

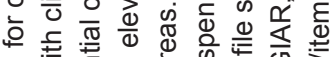

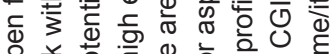

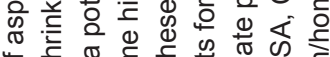

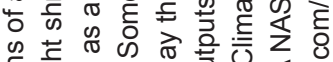

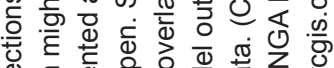

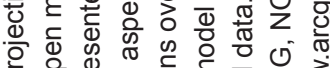

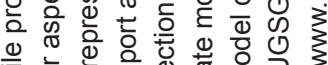

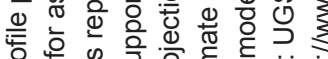

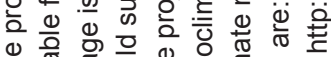

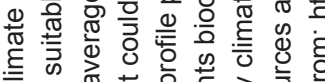
U. $\checkmark$ 元

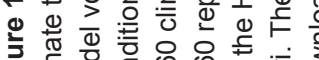

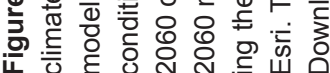


Aspen establishment or range expansion can be enhanced when disturbance removes conifer competition (Kulakowski et al. 2013a; Landhausser et al. 2010), or when aspen suckers or seedlings are protected from herbivory (Kay and Bartos 2000). Additionally, aspen types may also react differently to climate change and disturbance, and the different responses need to be considered in addition to bioclimatic model projections and other environmental factors.

Aspen grow on a variety of soil types. Aspen does well on soils rich in organic matter and minerals of the Mollisol soil order (Cryer and Murray 1992), soils derived from basic igneous rock like basalt, and soils derived from neutral or calcareous shales or limestones (Howard 1996). However, aspen can also exist on lithic, poorly developed soils (which contain large amounts of debris from previously formed rocks) that have lower productivity (Shepperd, U.S. Forest Service, Colorado State University, personal communication 2015). The National Forest lands in the Wasatch Range have aspen on soils derived from 24 different rock types (table 3 and fig. 15). The National Forest lands in the Uinta Mountains have aspen on soils derived from 14 different rock types (table 3 and fig. 16). The rock types underlying aspen with the most area are conglomerate and sandstone in the Wasatch Range, and sandstone and arenite in the Uinta Mountains (table 3).

Aspen range movement can be hindered by browsing, competition with conifers, slow rate of spread, unavailable area with suitable soils, or environmental conditions. Aspen establishment can also be hindered by changes in soil properties as a result of conifer presence (Buck and St. Clair 2012), or by ungulate over-browsing (Kay and Bartos 2000). Fire or other disturbance that opens the tree canopy is required for aspen persistence over time since aspen can be outcompeted and succeeded by shadetolerant conifers, such as Engelmann spruce, subalpine fir, or lodgepole pine (Mueggler 1985b; Smith and Smith 2005; Calder et al. 2012). Conifer presence in aspen stands lowers light levels and changes soil chemistry by reducing nutrients such as nitrogen, disadvantaging aspen in the same stands (Calder et al. 2011; Smith and Smith 2005). Aspen above and below ground growth and biomass is less in mixed conifer-aspen stands compared to pure stands (Shepperd et al. 2001). Aspen seedling establishment and upslope expansion in west-central Alberta, Canada, was found to be highest on exposed mineral soils, and the highest numbers of seedlings were found on concave microsites in areas of moisture collection (Landhausser et al. 2010); thus, topography can enhance or limit aspen establishment. Elevation range shifts may also be constrained by the slow spreading of lateral roots and hence by suckering, which is 1 to 2 tree heights away from an existing tree (Shepperd et al. 2001). Given that aspen have limited upslope areas in the Wasatch Range especially, and that soil conditions, slow spreading reproduction ability, and herbivory can inhibit their range expansion, vulnerability of this criterion is high (fig. 17). 
Table 3-Rock type and the percentage of National Forest land occupied by aspen for the Wasatch Range and Uinta Mountains.

Rock type data source: USGS. Aspen location data source: USDA (2013a).

\begin{tabular}{|c|c|c|c|c|c|}
\hline $\begin{array}{l}\text { Wasatch Range rock } \\
\text { types on National } \\
\text { Forest land }\end{array}$ & $\begin{array}{l}\text { Area (acres) of } \\
\text { aspen occupy- } \\
\text { ing rock type }\end{array}$ & $\begin{array}{c}\text { Percent of National } \\
\text { Forest land rock } \\
\text { type occupied by } \\
\text { aspen }\end{array}$ & $\begin{array}{l}\text { Uinta Mountains rock } \\
\text { types on National } \\
\text { Forest land }\end{array}$ & $\begin{array}{l}\text { Area (acres) } \\
\text { of aspen } \\
\text { occupying } \\
\text { rock type }\end{array}$ & $\begin{array}{c}\text { Percent of National } \\
\text { Forest land rocky } \\
\text { type occupied by } \\
\text { aspen }\end{array}$ \\
\hline conglomerate & 95,807 & 27 & sandstone & 48,572 & 22 \\
\hline sandstone & 76,817 & 16 & arenite & 27,289 & 4 \\
\hline dolostone (dolomite) & 31,315 & 13 & glacial drift & 23,545 & 4 \\
\hline limestone & 23,516 & 11 & conglomerate & 23,042 & 12 \\
\hline shale & 21,916 & 11 & shale & 10,019 & 32 \\
\hline gladial drift & 11,225 & 18 & alluvium & 8,875 & 8 \\
\hline metamorphic rock & 10,810 & 16 & dacite & 7,931 & 26 \\
\hline arenite & 10,218 & 11 & landslide & 7,518 & 13 \\
\hline mudstone & 9,388 & 13 & limestone & 6,389 & 12 \\
\hline carbonate & 7,984 & 15 & dolostone (dolomite) & 5,648 & 18 \\
\hline alluvium & 7,030 & 5 & $\begin{array}{l}\text { fine-grained mixed } \\
\text { clastic }\end{array}$ & 4,871 & 22 \\
\hline $\begin{array}{l}\text { fine-grained mixed } \\
\text { clastic }\end{array}$ & 6,022 & 13 & mudstone & 4,186 & 25 \\
\hline $\begin{array}{l}\text { medium-grained } \\
\text { mixed clastic }\end{array}$ & 4,633 & 12 & quartzite & 1 & 0.2 \\
\hline granodiorite & 3,080 & 11 & oil shale & 0.4 & 0.0009 \\
\hline dacite & 1,506 & 3 & & & \\
\hline quartzite & 452 & 21 & & & \\
\hline orthoquartzite & 168 & 21 & & & \\
\hline siltstone & 108 & 9 & & & \\
\hline clay or mud & 87 & 0.4 & & & \\
\hline landslide & 76 & 6 & & & \\
\hline $\begin{array}{l}\text { coarse-grained mixed } \\
\text { clastic }\end{array}$ & 201 & 5 & & & \\
\hline ash-flow tuff & 15 & 18 & & & \\
\hline rhyolite & 3 & 13 & & & \\
\hline folian & 1 & 0.1 & & & \\
\hline
\end{tabular}




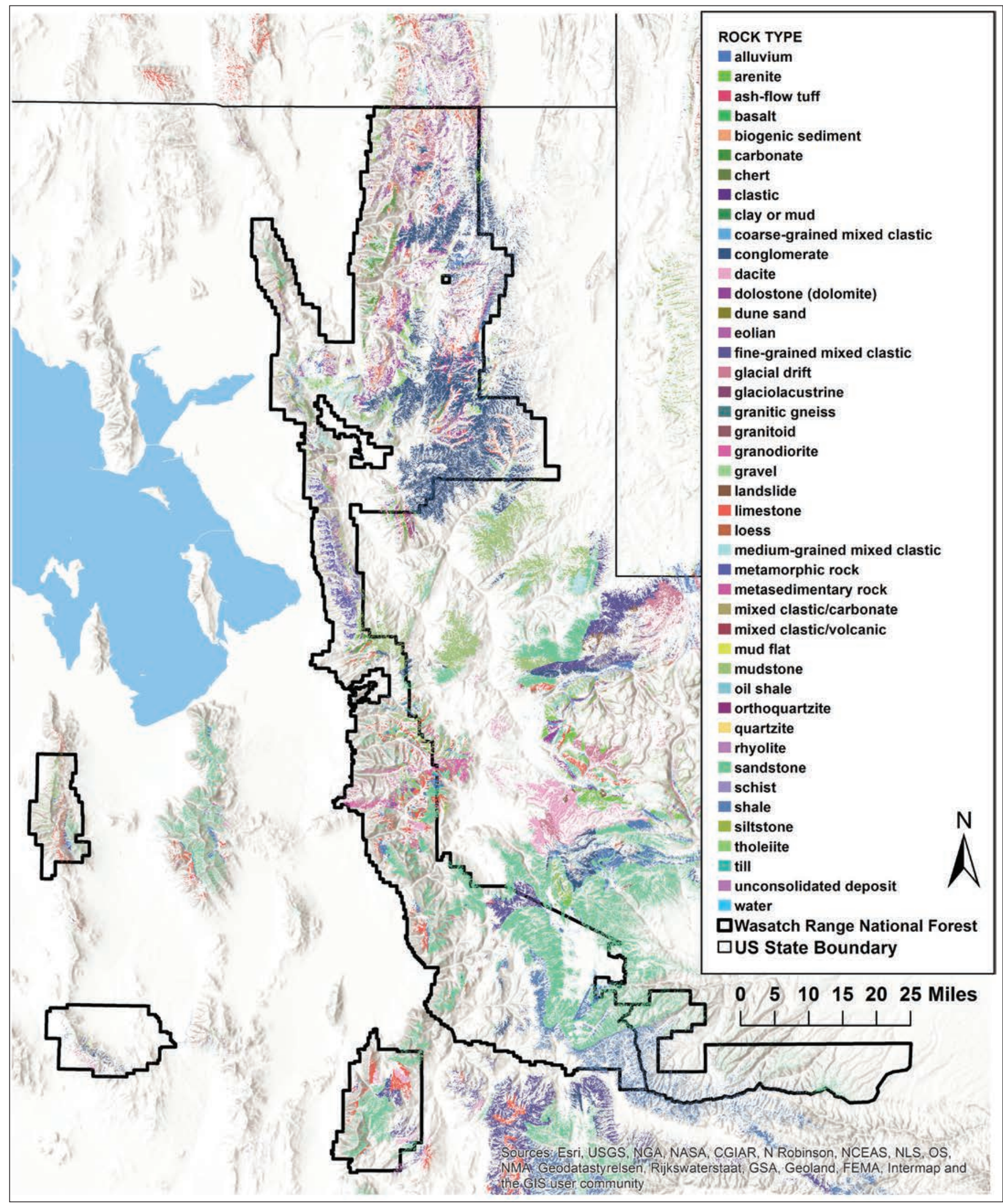

Figure 15-Wasatch Mountain Range rock types underlying aspen distribution. Colored areas are soil types where aspen occurs. (Aspen location data USDA (2013a). Rock Type data source: USGS. http://mrdata.usgs.gov/geology/state/. Hillshade background from: Esri. Their sources are: UGSG, NGA NASA, CGIAR, N Robinson, NCEAS, NLS, OS, NMA, Geodatastyrelsen, Rijkswaterstaat GSA, Geoland, FEMA, Intermap, and the GIS User Community. Downloaded from: http://www.arcgis.com/home/item.html?id=9c5370d0b54f4de1b48a3792d7377ff2.) 


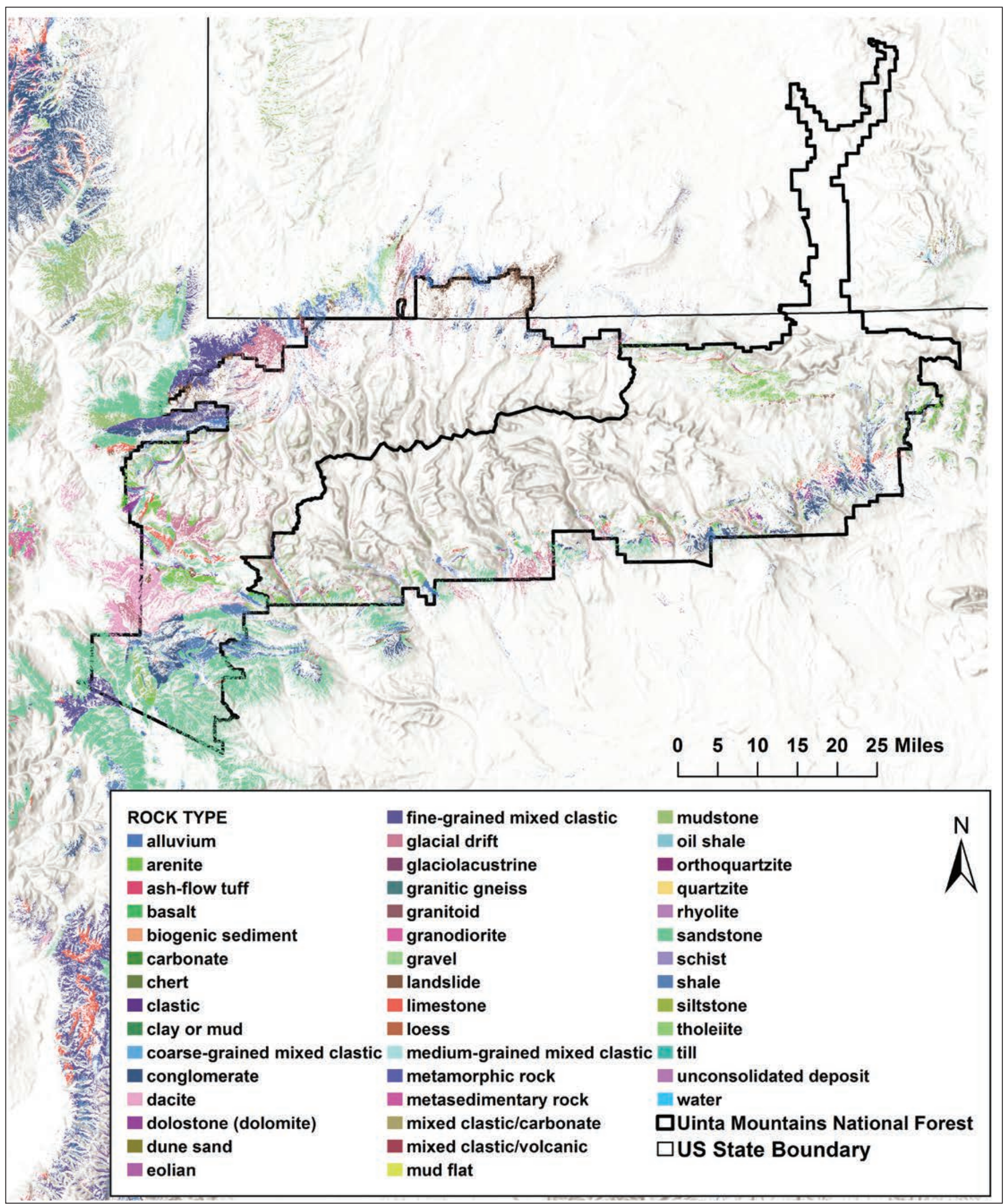

Figure 16-Uinta Mountain Range rock types underlying aspen distribution. Colored areas are where aspen occurs. (Aspen locations USDA (2013a). Rock type data source is USGS. http://mrdata.usgs.gov/geology/state/. Hillshade background from: Esri. Their sources are: UGSG, NGA NASA, CGIAR, N Robinson, NCEAS, NLS, OS, NMA, Geodatastyrelsen, Rijkswaterstaat GSA, Geoland, FEMA, Intermap, and the GIS User Community. Downloaded from: http://www.arcgis.com/home/item.html?id=9c5370d0b54f4de1b48a3792d7377ff2.) 


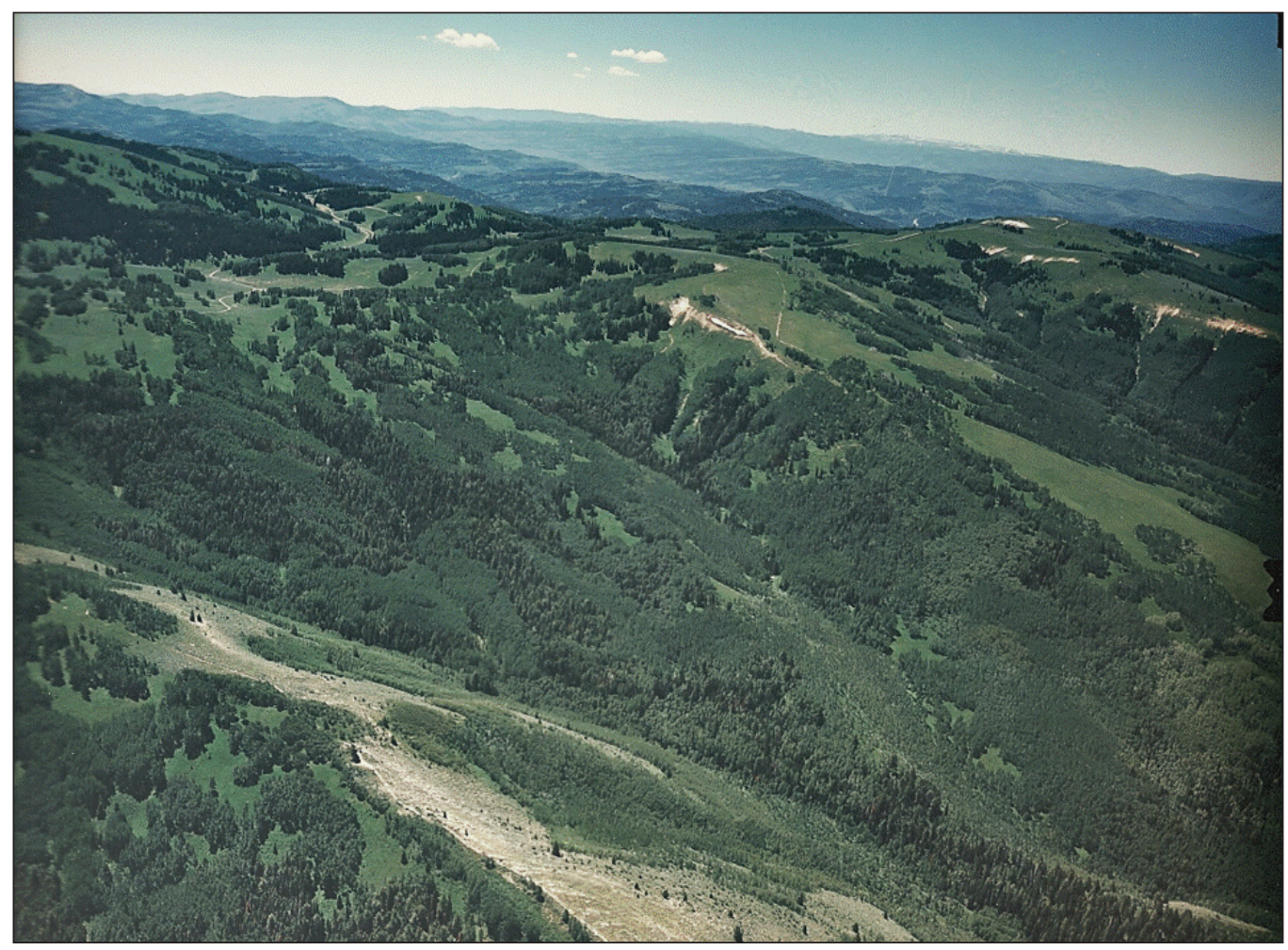

Figure 17-Aspen landscape with potential range shift areas if suitable conditions allow: (photo by A. Huber).

\section{Vulnerability of Aspen-Associated, Cold-Adapted Foundation or Keystone Species to Climate Change}

Summary: A range of low to high vulnerability is assigned for species in aspen ecosystems because some will likely persist and adapt or take advantage of changes in environmental conditions, while others will be hampered by climate warming and drying.

- Understory vegetation associated with aspen has low to high vulnerability to climate change, as vulnerability varies with environmental conditions and plant tolerances to warmer and drier conditions. Species such as grasses, shrubs, and some forbs may expand during drier and warmer conditions. Understory species relatively shaded by aspen cover may also have a lower vulnerability. Other species, for example some forbs, that are exposed to heat and drought beyond tolerance levels likely have a high vulnerability.

- Birds associated with aspen communities are likely to have a low to high vulnerability to climate change. Vulnerability varies depending on bird life history habits. Drought and heat associated with climate change can hamper birds, but some species can benefit (for example, drier conditions that promote more fire may benefit birds that benefit from a young forest structure). Birds that are dependent on mature forest structure (for example, goshawk) may have a higher vulnerability if climate change reduces the amount of mature forests or reduces tree sizes.

\section{Information confidence:}

- Moderate vulnerability of understory vegetation is supported by nine studies, five of which are in Utah or northeast Utah, one from the Blue Mountains, Oregon, and three from Colorado.

- Moderate vulnerability of birds is supported by seven studies. Species-specific information on vulnerability is limited. 
A set of species living in aspen ecosystems is selected to capture different influences on ecological function, the range of biotic environmental tolerances, and vulnerability to climate conditions that are expected to develop in the Wasatch and Uinta Mountain Ranges. Understory vegetation is selected as it provides forage for a wide variety of animals and has high biodiversity. Birds are selected as they have a high diversity in aspen forests and depend on insects and plants in aspen forests. Cold-adapted species were not identified or included in this assessment. The foundation and keystone species that dominates aspen ecosystems are aspen trees, which are addressed in the other criteria of this assessment. Pollinators have a symbiotic relationship with understory plants, but limited information is available to assess their vulnerability on these forests.

\section{Understory Vegetation}

Grasses, forbs, and shrubs in aspen understories have high diversity, richness, and productivity compared to other forest types (Chong et al. 2001; Mueggler 1985a). The Mueggler (1988) study that compiled aspen communities across Utah, Idaho, and Nevada found that three communities were prevalent in persistent aspen stands of the Wasatch Range and Uinta Mountains. These stands had communities of (a) persistent aspen with understory tall forbs (common in the Wasatch Range but not the Uinta Mountains), (b) persistent aspen with the shrub Symphoricarpos oreophilus (common in the Uinta Mountains) mixing with forbs and grasses, or (c) persistent aspen with both Symphoricarpos oreophilus and Amelanchier alnifolia shrubs that mixed with forbs and grasses. Other shrubs also mixed with the dominant shrub species mentioned above, such as Prunus virginiana, Rosa woodsia, or Pachystima myrsinites. Some of the forbs in these stands included: Valeriana occidentalis, Osmorhiza occidentalis, Hackelia floribunda, Delphinium occidentale, Thalictrum fendleri, and Geranium viscosissimum (see Mueggler 1988 for full list). Grasses such as Bromus carinatus, Agropyron tachycaulum, Elymus glaucus, and Poa pratensis and the sedge Carex hoodii were also found in the shrub communities mixing with the persistent aspen types on the Wasatch Range and Uinta Mountains. The most common community types found in the Uinta Mountains are seral and persistent aspen mixing with Symphoricarpos oreophilus shrubs and grasses Calamagrostis rubescens or Bromus carinatus. Another common aspen community type in the Uinta Mountains is aspen mixing with Juniperus communis and the sedge Carex geyeri (Mueggler 1988).

Mueggler (1988) found 2 major and several minor or incidental seral aspen community types that were in the Uinta Mountains and Wasatch Range. These communities were (a) seral aspen mixing with Abies lasiocarpa and tall forbs (tall forbs being uncommon in the Uinta Mountains) or (b) seral aspen mixing with Abies lasiocarpa and graminoids Carex rossii or Bromus anomalus. Picea engelmannii was often with the Abies lasiocarpa trees in the seral aspen. Tall forbs that were common, especially in the Wasatch Range, were: Rudbeckia occidentalis, Aster engelmannii, Valeriana occidentalis, Delphinium occidentalis, and Osmorhiza occidentalis. A shrub layer was sometimes 
present with Symphoricarpos oreophilus (especially in the Uinta Mountains), Rosa woodsii, and Berberis repens. Minor or incidental occurrences of seral aspen community types on the Uinta Mountains included aspen mixing with Pinus contorta or Abies lasiocarpa in conjunction with Juniperus communis in the understory. Seral aspen also mixed with Pinus ponderosa and had understory species of Symphoricarpos oreophilus, Berberis repens, Poa fendleriana, Taraxacum officinale, and Achillea millefolium. Seral aspen was found mixing with Picea pungens and had understory species of Taraxacum officinale, Achillea millefolium, Symphoricarpos oreophilus, Bromus anomalus, Fragaria vesca, and Poa pratensis. The seral aspen also mixed with Pinus contorta and had the sedge Carex geyeri dominating the understory. Pseudotsuga menziesii mixed with aspen and the understory was dominated by Symphoricarpos oreophilus or Juniperus communis. Other minor and incidental occurrences in the Wasatch Range included seral aspen mixing with Pinus contorta and the understory shrub Symphoricarpos oreophilus or the forbs Thalictrum fendleri with Achillea millefolium in some stands. In the Bear River Mountains of the Wasatch Range, aspen mixed with Abies lasiocarpa and the shrubs Shepherdia canadensis, Symphoricarpos oreophilus, or Amelanchier alnifolia, or the sedge Carex geyeri. See Mueggler (1988) for a full description of seral aspen species and community types in the Wasatch Range and Uinta Mountains.

Warming and drying may inhibit the growth and survival of some understory plants, while others may benefit and expand. Aspen dieback from drought in seral aspen types of southwestern Colorado caused understory communities to shift structure and to reduce forb cover and richness (Anderegg et al. 2012a). This study found increased shrub cover in aspen stands affected by sudden aspen mortality, suggesting a potential conversion to shrub cover. A study by Korb et al. (2014) in seral aspen stands of southwestern Colorado found understory species that were associated with high aspen mortality stands were: yarrow (Achillea lanulosa), aspen fleabane (Erigeron speciosus), harebell (Campanula rotundifolia), and sego lily (Calochortus nuttallii). This suggests that these species are benefitted by the loss of aspen dieback during drought. The Korb et al. (2014) study also found grass biomass was higher in stands with high aspen mortality from sudden aspen mortality events compared to stands with low aspen mortality rates. Understory shrubs, dominated by roundleaf snowberry (Symphoricarpos rotundifolius), were not found to differ across different amounts of aspen mortality, suggesting that shrubs are resistant to the effects of drought and heat-induced mortality of aspen (Korb et al. 2014). The shift in aspen understory composition observed in southeastern Colorado may be an example of how understory vegetation may respond if drought-induced aspen dieback occurs in Utah forests. Some understory species, such as roundleaf snowberry, grasses, and the forbs mentioned above, may be more tolerant to drought and heat, which may lower their vulnerability to the expected increase in drought and warmer temperatures that would cause aspen dieback. 
The effects of climate change on understory species may be reduced or magnified as a result of aspen stand structure and tree canopy composition. Moisture stress on understory vegetation may be reduced by a leafed out persistent aspen stand that reduces air movement. Wind velocity at 5 feet above the ground was measured at almost 0 when winds were above 25 miles per hour above the tree canopy in north central Utah (Shepperd and Jones 1985), so understory vegetation in mature, persistent aspen stands are less exposed to drying from wind. Conversely, moisture loss and drying can be magnified by ungulate browsing of aspen suckers and understory vegetation. Browsing causes reduced understory and lower volume tree canopies as was found in the Bear River Mountains in northeastern Utah (Carter and Chard 2011) and Blue Mountains in Oregon (Endress et al. 2012). (Also see section on Climate Change and Grazing). Stam et al. (2008) found on the Dixie and Fishlake National Forests in southeastern Utah that the presence of as little as 10 to 20 percent conifer cover in aspen stands can reduce understory productivity.

As specific information on climate change vulnerability for the numerous aspen understory species is limited, a range of vulnerability from low to high is assigned. Species in the aspen understory may respond differently to climate change according to environmental tolerances to heat and drying, stand conditions, community composition, conifer presence, and the degree of herbivory and disturbance. Understory species in areas where drought and heat exceed tolerance levels have a high vulnerability to climate change - whereas other species may have low vulnerability since they are more tolerant of warmer and drier conditions. For example, shrubs, grasses, and some forbs may persist and become more dominant in the understory community during drought periods. Some understory species in persistent aspen stands may also have a low vulnerability since the tree canopy provides protection from heat and drying.

\section{Birds}

A large diversity of birds use aspen ecosystems, including birds of prey, small birds or songbirds, cavity nesters, and game birds. Here, we draw on the literature for birds in western United States aspen forests because few studies have been conducted in the Wasatch Range and Uinta Mountains. We assume similar characteristics for birds in these Utah mountain aspen stands. Common nighthawks and birds of prey occupying aspen stands can include the great horned owl, and northern goshawks, which have been observed nesting in aspen stands (Goshawk monitoring data, Ashley NF 2014b). Game birds can include ruffed grouse and mourning doves. Cavity nesting birds can include northern flicker, red-naped sapsucker, hairy woodpecker, downy woodpecker, Lewis's woodpecker, house wren, mountain bluebird, and black-capped and mountain chickadees. Several small birds use aspen forests: warbling vireo, yellow-rumped warblers, chipping, white-crowned, and song sparrows, American robin, Swainson's and hermit thrush, western wood peewee, dusky flycatcher, the breeding broad-tailed hummingbird, and the migrating rufous hummingbird (Debyle 1981). On the Ashley NF, the top 5 most abundant species in aspen forests over 2 years of surveys were the warbling vireo, yellow-rumped warbler (Audubon's race), dark-eyed junco, American robin, and 
hermit thrush (Bird Surveys, Ashley NF 2014a). Not all aspen-associated birds nest in aspen stands, however; as Debyle (1981) noted in a Utah study, of the 33 bird species he observed in a 10 acre aspen stand in the Wasatch Range, 12 to 19 species nested in aspen over a 4-year period, while others utilized aspen but did not breed there. The bird diversity in mixed aspen-conifer forests is probably the highest, as there are a diverse set of niches in this forest type (Debyle 1985c).

Bird species composition and populations are tied to forest structure, which is influenced by climate and disturbance. Aspen-associated cavity nesting birds may benefit from disturbances in nearby conifer forests or seral aspen types that create more food (for example, bark beetles) and snags that provide more nesting and shelter habitat. Bird populations and survival rates were found to increase in conifer forests of British Columbia after bark beetle outbreaks that made more food and nesting resources available (Edworthy et al. 2011; Norris et al. 2013). A study by Kulakowski et al. (2013b) in northwestern Colorado subalpine forests found that compound disturbances from fire, conifer bark beetle outbreaks, and wind events reduced regeneration of conifers and favored initial stand dominance of aspen. They hypothesized that since aspen are less susceptible to fire, bark beetles, and wind than conifers, the probability and severity of future disturbance may eventually be diminished by an increased dominance of aspen after an increase in disturbance reduces conifer presence. Aspen-associated birds may benefit if aspen trees increase as a result of more fire and conifer bark beetle outbreak activity due to climate change that give aspen a competitive advantage.

Species that prefer a mature forest structure may be hampered by a loss of mature trees associated with the climate warming and drying and more fire. The northern goshawk (Squires and Reynolds 1997) and blue grouse, yellow-rumped warbler, warbling vireo, dark-eyed junco, house wren, and hermit thrush (Debyle 1981) are examples. The MacGillivray's warbler, chipping and song sparrows, and lazuli bunting have historically occurred in younger aspen stands in northern Utah (Debyle 1981). These species would likely not be hampered if a younger forest structure developed with warmer and drier conditions and more frequent fire.

Drought, which is projected to increase in frequency, duration, and severity (Ault et al. 2014) that causes stress to birds may also have variable effects. The Smith (1982) study in northern Utah and southern Idaho found that during the drought of 1977, the density of insect-eating birds declined, hummingbirds were absent, and seed-eating finches increased in a mixed meadow-aspen-spruce-fir landscape of northern Utah. Bird population density declined markedly in the aspen stands and only slightly in the spruce-fir during this drought (Smith 1982).

The Cornell Lab of Ornithology (2014) has noted an overall 20 percent decline in bird populations in western U.S. forests since the late 1960s. Major threats to these forests are noted as exurban development and exotic insect pests and diseases. Birds associated with western aspen and other forests have had mixed population changes from 1968 to 2012 (National Audubon Society (2014). The Hammond's flycatcher increased 
0.5 percent per year, lazuli bunting increased 0.2 percent per year, and the blackheaded grosbeak increased 0.9 percent per year, all of which are associated with other forest types. Declining bird populations included the MacGillivray's warbler ( -1.1 percent per year), the rufous hummingbird ( -2 percent per year), the western wood peewee $(-1.6$ percent per year), and the dusky flycatcher $(-0.7$ percent per year).

Species-specific information about how bird populations change in response to warmer and drier climate and forest disturbance is needed. Available information points to a mixed vulnerability of aspen-associated birds. Bird species sensitive to drought or dependent on mature aspen trees likely have a high vulnerability. More frequent drought and a loss of mature aspen stands may occur with more frequent fire. Other birds able to capitalize on changing conditions such as more snags from bark beetle outbreaks or younger forest structures are likely to have a low vulnerability. Thus, birds' vulnerability is likely to span from low to high vulnerability to climate change.

\section{Limited Knowledge}

\section{Pollinators}

Pollinators could be hindered by the changes in climate. Very few studies have been conducted on these forests with respect to the potential impacts of climate change on pollinators. Even more broadly, there is limited understanding of the complex interactions between plants and pollinators under climate change (Forrest 2015). Pollinators provide a supporting ecosystem service that ensures seed production and maintains understory plants. Pollinators add biodiversity to aspen stands and the surrounding landscape. Warren et al. (1988) study in the Wasatch Range and Uinta Mountains found that the insect order hymenoptera (sawflies, wasps, bees, and ants) dominated at about 5,000 feet elevation, while the insect order lepidopterans (butterflies and moths), and more commonly dipterans (flies), dominated in subalpine meadows at 10,500 feet elevation. Because of the important services that pollinators provide, we review literature from other areas assuming similar traits and characteristics for pollinators in the Uinta-Wasatch-Cache and Ashley NFs. Additional study is needed to determine the application of these results to the Uinta-Wasatch-Cache and Ashley NFs.

Pollinators could be hindered by the direct effects of a changing climate or by the climate-change responses of plants they pollinate. Snowpack loss may play a role in hampering pollinators; for example, Rocky Mountain Apollo butterfly eggs and larvae may lose insulating snow cover and not survive winter freezing as was found in meadows of Alberta, Canada (Matter et al. 2011). Droughts and heat waves have been noted to cause a strong decline in bumble bees in Europe, and their late summer phenology puts them at higher risk of exposure to drought and heat (Rasmont and Iserbyt 2012). Pollinators may be more vulnerable to bloom scarcity during dry years, or when early spring frost damages and reduces flower abundance, as has been found in the montane and subalpine meadows of the western Colorado Rockies (Aldridge et al. 2011; Inouye 2008). Generally, pollinators advance their phenology earlier than plants in response to environmental cues, such as warming (Schweiger et al. 2010). While these responses 
may decouple the timing of blooming plants with pollinator availability, most evidence to date suggests that earlier blooming and emergence of pollinators is not a major threat to pollinators (Forrest 2015; Forrest and Thomson 2011; Iler et al. 2013; Gezon et al. 2016). Fragmentation of habitat, invasive species, and habitat degradation has also been noted to play a role in hampering pollinators globally (Schweiger et al. 2010)

\section{Sensitivity to Extreme Climatic Events (Drought, Heat, Floods)}

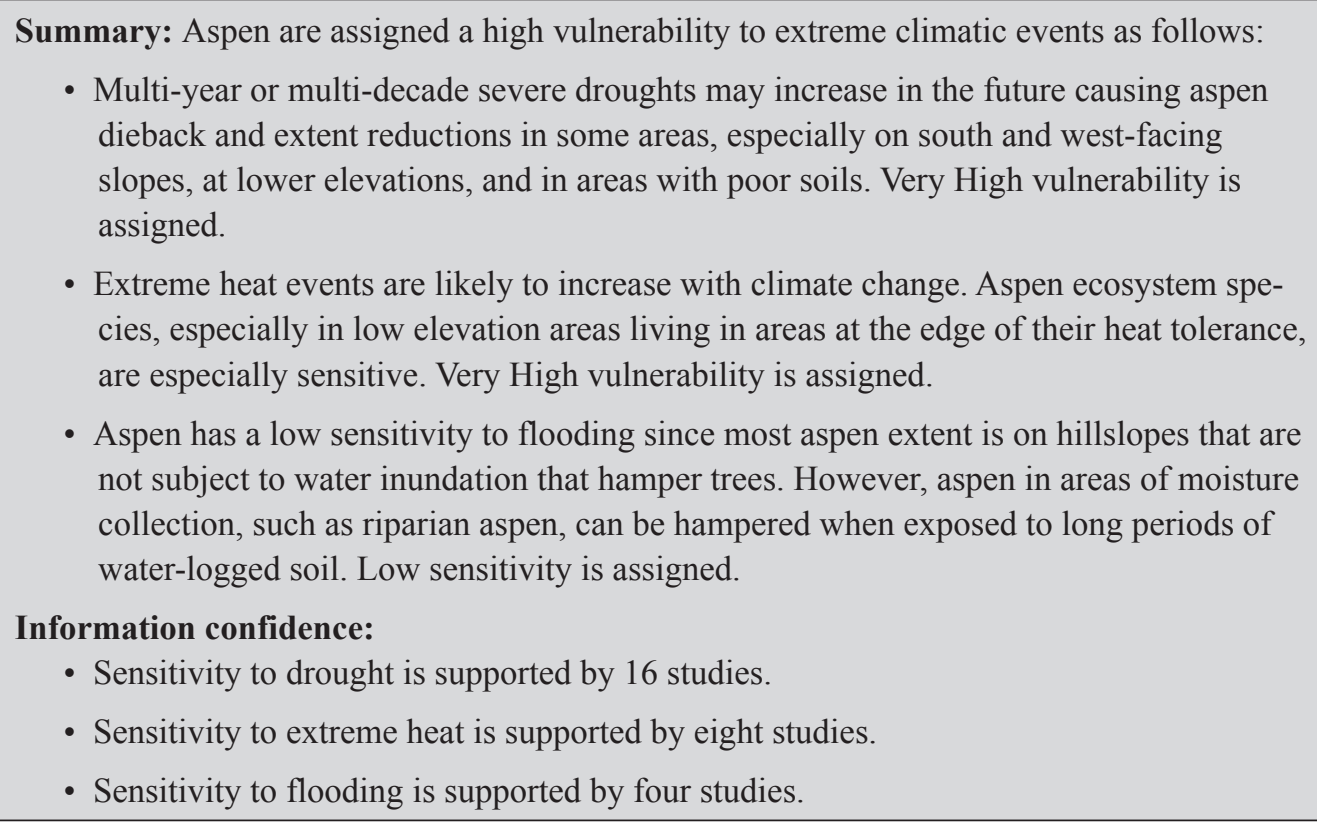

- Extreme heat events are likely to increase with climate change. Aspen ecosystem species, especially in low elevation areas living in areas at the edge of their heat tolerance, are especially sensitive. Very High vulnerability is assigned.

- Aspen has a low sensitivity to flooding since most aspen extent is on hillslopes that are not subject to water inundation that hamper trees. However, aspen in areas of moisture collection, such as riparian aspen, can be hampered when exposed to long periods of water-logged soil. Low sensitivity is assigned.

Information confidence:

- Sensitivity to drought is supported by 16 studies.

- Sensitivity to extreme heat is supported by eight studies.

- Sensitivity to flooding is supported by four studies.

\section{Sensitivity to Drought}

Historical droughts (below average precipitation over an extended period) in the Wasatch Range and Uinta Mountains have mostly associated with below-average cold season (October-March) precipitation, a season during which most of the annual precipitation falls (MacDonald and Tingstad 2007). Decreased precipitation in the cold season lengthens the duration of summer water deficits.

Future drought may become more intense and prolonged. Kunkel et al. (2013) had such high model agreement ( $>67$ percent) that the consecutive number of dry days would increase 5 to 10 days per year in northern Utah by the mid- $21^{\text {st }}$ century. Ault et al. (2014) projected the risk for decade-scale mega drought to be 80 percent at the end of this century for the southwestern United States. Cook et al. (2015) found that drought across the southwestern United States would significantly exceed those of the worst drought period since the Medieval Warm Period during the 1200s. Their study had high model agreement across 17 models under both a moderate and high climate warming scenario. Higher elevations may not experience as much drying or drought since cooler temperatures and more precipitation are characteristic of these areas (Lukas et al. 2014). However, some snowpack loss is projected for higher elevations, although 
less than lower elevation snowpack loss (Christensen and Lettenmaier 2007). Snow as a percent of winter precipitation is projected to change from 90 percent to less than 50 percent in many areas of the Wasatch Range by mid-century (Klos et al. 2013). This would contribute to drier conditions in the Wasatch Range late in the growing season that could intensify the effects of drought and hamper biota. In contrast, the Uinta Mountains are projected to retain more than 90 percent of winter precipitation as snow (Klos et al. 2013) (see Climate section of this report).

Aspen ecosystems are highly sensitive to multi-year severe drought since aspen trees have a low tolerance (Worrall et al. 2008; Korb 2012), and other aspen ecosystem biota can be hindered by drought as well as (see Vulnerability of Aspen-Associated, Cold-Adapted Foundation or Keystone Species to Climate Change section above). Rapid aspen tree dieback has been attributed to drought during the 2000s in North America (Worrall et al. 2013). Aspen dieback in Utah was estimated at about 9 percent of the aspen forest type from 2002 to 2007 (Worrall et al. 2013). Anderegg et al. (2015) southwestern Colorado study found that the lethal water stress threshold for aspen was reached during the early 2000 s drought. This corresponded to a loss of vascular transport capacity in the tree from air entering into the xylem (the vascular tissue in plants that conducts water and dissolved nutrients upward from the root). After the drought ends and soil moisture is higher, the legacy of drought, xylem cavitation (where high water tensions cause sap to vaporize and air fills the chamber) in branches and in roots still remains, which reduces water transport from soil to above ground tree parts (Anderegg et al. 2012b). Anderegg et al. (2014) found that the drought damaged aspen trees had a 5 -fold lower hydraulic conductivity and a 7-fold lower assimilation than aspen trees not damaged by drought.

Stand structure and age may play a role in aspen sensitivity to mortality from drought. Bell et al. (2014) found that forest structure and successional stage affected the degree of mortality in stands. High densities, basal areas, tree diameters, and low stand age were modeled to be more sensitive to mortality associated with drought in the Rocky Mountains and Intermountain Region. Post-successional stage stands that survived without encroachment by conifers with low basal areas, low stand densities, and high-age stands were the least sensitive to mortality from drought. Korb (2012) observed that in pure aspen stands of western Colorado, the highest levels of dieback were associated with larger diameter trees ( $>12 \mathrm{~cm}$ diameter breast height), low basal area, and low stand density.

Aspen dieback has been associated with southern to western-facing slopes, and also with lower elevations, top slope positions, and poor soils (Evans 2010; Worrall et al. 2010, 2008, 2013). On the Uinta-Wasatch-Cache and Ashley NF, 34 percent of total aspen stand area are on south-facing slopes and 22 percent on west-facing slopes (derived from GIS data not shown). Given the high sensitivity of aspen to multi-year severe drought, a very high vulnerability is assigned to this criterion. 


\section{Sensitivity to Extreme Heat}

Climate models have high agreement that more extreme heat will occur in the future. Temperature projections compared to late $20^{\text {th }}$ century data indicate an increase of 5 to 10 days per year in the number of days that temperatures exceed $95^{\circ} \mathrm{F}$ by the mid- $21^{\text {st }}$ century for northern Utah (Kunkel et al. 2013). The most extreme heat days are projected for the lower elevations around the Uinta Mountains and Wasatch Range (see figure 23 in Kunkel et al. 2013).

Aspen are greatly hampered by extreme heat. Aspen tree photosynthesis declines at air temperatures above $77^{\circ} \mathrm{F}$ (Lieffers et al. 2001). The aspen clone, or group of individual trees connected by a shared root system, has optimal growth when soil temperatures are $74{ }^{\circ} \mathrm{F}$ (Perala 1990). Aspen trees living in stands that have had portions die from drought are particularly susceptible to heat stress as the remaining live trees receive more solar radiation (Korb et al. 2014). Extreme temperatures magnify the effects of drought, further hampering aspen trees or reducing tree populations (Hogg et al. 2008; Worrall et al. 2008), as well as birds, flowering herbs, and aspen understory insects (Smith 1982).

Aspen stand topographic position and stand structure can raise or lower the effects of extreme heat. Aspen on south and west-facing slopes and lower elevations can have amplified exposure to heat compared to other aspects (see Sensitivity to Drought section above). In addition, heat is increased when canopy cover is reduced, such as with sudden aspen mortality (Korb et al. 2014), or when aspen layers within the canopy are reduced by over-browsing (Rogers 2015b). Aspen trees are susceptible to mortality during heat stress, especially during multi-year severe drought, and are assigned a very high vulnerability to extreme heat. Lower elevations are especially sensitive since extreme heat is projected to be more intense there.

\section{Sensitivity to Floods}

The future may hold more intense flooding in northeastern Utah. Kunkel et al. (2013) project the number of days with precipitation $>1$ inch increases by 10 to 50 percent in northern Utah $(<50$ percent model agreement). As discussed in the Climate section above, there is high model agreement ( $>70$ percent) that winters will become slightly wetter in the Wasatch Range and Uinta Mountains, with more rain, especially in the Wasatch Range. However, future flooding risk and the magnitude or timing of changes in precipitation is not clear.

Topographic position affects aspen sensitivity to flooding in different ways. Aspen ecosystems that are in areas of moisture collection or along streams may be most susceptible to water inundation by flooding. High soil moisture can promote fungal diseases in aspen trees (Hinds 1985). Aspen tree regeneration by root suckering was found to be reduced by increased flooding and flooding in combination with warmer temperatures (Bates et al. 1998). Areas inundated by water over several years can kill aspen roots, which has been observed near beaver dams (Debyle 1985a). Aspen in 
upslope areas may be less exposed to water inundation from flooding, as these areas do not collect moisture. However, intense flooding can cause landslides in upslope areas, which could result in areas of stand mortality. Most aspen ecosystems in the Uinta-Wasatch-Cache and Ashley NFs are on hillslopes, and given that an extended time period of water inundation or an intense flood that causes a landslide is needed to hamper aspen, they are likely to have a low sensitivity to flooding that may become more intense in the future.

\section{Intrinsic Adaptive Capacity}

Summary: Factors both raise and lower vulnerability, moderate vulnerability is assigned.

Factors: raising adaptive capacity are as follows:

- Aspen trees have mechanisms that increase its water use efficiency and heat tolerance, raising its ability to adapt to climate change.

- Aspen have high biodiversity and productivity and the ability to recover quickly after disturbances such as fire, which raise its adaptive capacity.

Factors that lower adaptive capacity:

- Aspen are susceptible to numerous insects and diseases and are hampered by competition with conifers where they coexist with aspen. Seedlings are susceptible to over-browsing by ungulates. The ability of aspen to genetically adapt to new climate conditions requires seeding, which is episodic, and the amount of genetic adaptation possible may be overtaken by the rate of climate change.

Information confidence:

- Factors that strengthen adaptive capacity are supported by 24 studies.

- Factors that weaken adaptive capacity are supported by eight studies.

\section{Factors That Strengthen Adaptive Capacity to Climate Change}

\section{Aspen climate change adaptive mechanisms}

Aspen trees have many mechanisms that raise their adaptive capacity to drought and heat. Aspen leaf shape is such that it trembles at the slightest breeze (Jones and DeByle 1985b), which helps cool the leaves, raising the ability to withstand heat. Aspen transpire less water when leaves are not present (DeByle 1985b) and use less water than conifers (Gifford et al. 1984; Jones et al. 1985). More snowpack is accumulated in aspen stands as aspen tree structure allows for less canopy snow interception than conifers (DeByle 1985b). The higher amount of snow accumulation in aspen stands can increase water availability during the growing season and the amount of watershed runoff compared to conifer forests (Ryel et al. 2006). Additionally, trees in aspen clone systems have connected roots that can become less dependent on parent root systems as trees age or remain functionally interconnected for a generation or more (DesRochers and Lieffers 2001; Shepperd et al. 2006; Shepperd and Smith 1993). The connected root systems can benefit the whole clone system as trees that have tapped into the water table can transport water to other trees that don't have access to the water table (DeByle 1985b). Thus, aspen clones have strengthened adaptive capacity to drought and water stress. 


\section{Diversity and Life History Traits}

Plant, bird, and invertebrate diversity is higher in aspen ecosystems compared to other forest types (Chong et al. 2001; Griffis-Kyle and Beier 2003). When there is diversity among aspen clones, the response to environment can be more variable; for example, the timing of leaf out has been observed to be different among clones (Cottam 1954; Greene 1971). This enlarges the scope of environmental tolerances by biota, which may increase adaptive capacity.

Two major genetic clusters of aspen have been identified in North America: (a) a southwestern cluster with two subclusters occupying areas west of the Continental Divide and south of Washington, Idaho, and Montana, and (b) a northern cluster that is north of these boundaries that correspond to the area covered by ice in the last glacial maximum (Callahan et al. 2013). The southwestern cluster of which the Uinta-WasatchCache and Ashley NFs are located was determined to have less genetic diversity within populations compared to the northern cluster, but the populations across the landscape were more distinct from each other. The southwest cluster aspen populations are highly valuable from an evolutionary standpoint as they represent a large portion of aspen's genetic variation and evolutionary history (Callahan et al. 2013).

Reproductive and life history traits of aspen also serve to raise adaptive capacity. While aspen trees are relatively short lived, few live up to 200 years (Perala 1990). Clones vary in size and can propagate aspen ramets, potentially allowing genets (a group of genetically identical individuals that have originated from a single ancestor by suckering) to live for thousands of years (Ally et al. 2008; Kemperman and Barnes 1976). Aspen can reproduce by seed or by suckering from clones. Expansion of clones is rapid as new aspen shoots can sucker asexually after 1 year and form clones that vary in size and characteristics (Jones and Trujillo 1975). The growth of aspen ramets is rapid during the first 20 years, and roots can spread at a rate of 3 to 6 feet per year (Buell and Buell 1959; Perala 1990). The rapid growth of ramets serves to quicken recovery after a disturbance that kills or stresses parent aspen trees, such as fire, which can raise adaptive capacity.

Seed reproduction is a strong contributor to genetic diversity among aspen populations (Mock et al. 2008), which would expand the range of potential population responses to climate change and thus raise adaptive capacity. Aspen seed reproduction is not as common as by suckering, but seed reproduction has recently been found more common than previously thought, thus offering a potential means for aspen migration under climate change (Krasnow and Stephens 2015; Mock et al. 2008; Romme et al. 2005).

Genetic diversity can also increase adaptive capacity. One clone in central Utah named Pando is estimated at 114 acres (DeWoody et al. 2008), and many aspen genotypes have been found to be contained adjacent to this aspen grove. This signifies that aspen reproduction by seeding and genetic diversity in aspen stands is greater than 
previously thought (Long and Mock 2012). The ability of tree species to genetically adapt to changing climate conditions is greatest when there are large populations with high genetic variability and opportunities are available for more genetically adapted species to establish (Alberto et al. 2013). How aspen trees and other aspen-associated plant species might genetically adapt to future climate warming and drying is an area of research in need of further study.

\section{Factors That Weaken Adaptive Capacity}

Ability to adapt to multiple and severe stressors

Aspen extent reductions have been observed in the western United States and are attributed to: conifer competition, fire suppression, over-browsing by ungulates, or fluctuations in forest populations from intermittent fires that temporarily reduce tree populations (Bartos 2000; Bartos and Campbell 1998; Kashian et al. 2007; Kulakowski et al. 2013a; Worrall et al. 2013). Aspen are not adapted to shade, but facilitate the succession of shade-tolerant conifers. Bell et al. (2014) implied that conifer competition under warmer and drier conditions could accelerate the loss of aspen. While aspen reproduce quickly following disturbance, aspen dieback was attributed to multiple stressors of insects and pathogens killing aspen trees stressed by multi-year severe drought and heat (Worrall et al. 2010). Additionally, the rate of expected climate change may be too fast for plant adaptive responses to keep pace, a conclusion of 8 in 12 studies investigating this aspect (Franks et al. 2014). In the case of aspen, reproduction from seed is episodic, with reproduction typically from suckering. The seed reproduction would be required for gene flow that would allow a new generation of aspen to genetically adapt to a different climate.

\section{Dependence on Specific Hydrologic Condition}

Summary: Aspen ecosystems are not dependent on a narrow hydrologic regime but require adequate moisture for growth. Biota are not dependent on the form of moisture, and when they receive adequate moisture, they are likely to persist in the snow-dominated regime that will become more rain-dominated in the future. Moderate vulnerability is assigned.

Information confidence:

- Snowpack loss, especially at lower and mid-elevations, and future shifts to more rain are supported in the literature in the study area and outside of it (four studies included here). The effects of this shift to more rain in aspen ecosystems have three studies supporting them.

\section{Hydrologic Regime}

Aspen ecosystems in the Uinta Mountains and Wasatch Range receive most of their moisture from snow and occupy a snow-dominated hydrologic regime that is expected to shift to more rain in the future. Lower elevations may have rain as well as snowmelt influencing runoff and are an area of further study. The shift to more rain has already been happening across the State of Utah since the 1970s. As a result, snow depth and snow cover have also been trending lower in the State (Gillies et al. 2012). The trend 
does have year to year variability since precipitation and temperature vary across time. Annual precipitation in $8 \mathrm{Utah}$ aspen stands was found to vary from 16 to 44 inches (elevations varied from 7,200 to 9,850 feet) (Jones and DeByle 1985a). Jones and Horell (2008) projected snowpack loss to be elevation-dependent in the Wasatch Range. For a $1.8^{\circ} \mathrm{F}\left(1^{\circ} \mathrm{C}\right)$ temperature increase, snowpack loss ranged from 20 percent at the base to 4 percent at the top of the Ben Lomond Range. The Oquirrh Mountains southwest of Salt Lake City were projected to have a 16 percent loss at the base and 2 percent loss at the top with a $1.8^{\circ} \mathrm{F}\left(1^{\circ} \mathrm{C}\right)$ temperature increase (Jones and Horel 2008). By the mid- $21^{\text {st }}$ century, a transition from snow to more winter rain may also be more common in the Wasatch Range compared to the Uinta Mountains; see figure 9 in the Climate section of this report (Klos et al. 2014). Warmer temperatures may extend the growing season, but that shift from snow to more rain during winter may make it become drier late in the season.

\section{Hydrologic Regime Changes and Effects on Aspen Ecosystems}

Aspen ecosystems do not depend on a particular form of precipitation, but they do require adequate moisture for growth and reproduction throughout the growing season. Aspen reproduction by seed in early spring requires consistent soil moisture for success (McDonough 1985). Snow and accumulation of soil water and storage is higher in aspen stands compared to conifer forests (Burke and Kasahara 2011), but evapotranspiration during summer is higher in aspen (LaMalfa and Ryle 2008). The availability of moisture throughout the growing season can be compromised with earlier snowmelt that contributes to longer periods of moisture deficit, especially affecting late growing season growth. As discussed in the Sensitivity to Extreme Climatic Events section above, warmer temperatures resulting in more evaporation and more intense and longer periods of drought that are expected with climate change would compound the effects of less moisture availability late in the growing season, adversely affecting aspen and associated species.

The expected hydrologic regime shifts of more rain instead of snow are likely to have spatially variable effects on aspen. Some areas, such as lower elevations where species could exist at the edge of heat and moisture tolerances, may be more affected by loss of snowpack that contributes to drier growing season conditions. This could contribute to species dieback and hinder plant function and reproduction. At higher elevations (fig. 14), aspen may receive adequate moisture and species would suffer little to no adverse effects. The information on how changes in the hydrologic regime are likely to affect aspen ecosystems across the landscape is an area of further study. However, given the likelihood of aspen persistence in areas that will likely have adequate moisture throughout the growing season, such as at higher elevations, a moderate vulnerability is assigned to this criterion. 


\section{Potential for Climate Change to Exacerbate the Effects of Non- Climate Stressors, or Vice Versa}

Summary: Moderate vulnerability is assigned because climate change has potential to exacerbate the effects of non-climate stressors, specifically as follows:

- Climate warming, drought, and floods can intensify the effects of grazing that can reduce or stop aspen regeneration, especially when ungulate grazing is intense. High vulnerability is assigned.

- Future warming, drying, and less snowpack raise the potential for more frequent, severe, and larger fires and more conifer mortality from bark beetle outbreaks, thus lowering conifer competition for aspen. This would likely benefit aspen by promoting regeneration and the dominance of aspen on the landscape. Low vulnerability is assigned.

- Drought has been linked to increased susceptibility to insects and diseases. Future increases in the magnitude and intensity of drought could exacerbate the effects of insects and diseases, and vice versa. However, the regeneration of an aspen stand after a mortality event from drought and/or insects and diseases can occur if not imperiled by continued drought or over-browsing of ungulates. Moderate vulnerability is assigned.

Information confidence:

- Grazing and climate exacerbation is supported by 11 studies.

- Climate change exacerbation of fire and bark beetles is supported by 16 studies.

- Climate change exacerbation of insects and disease and sudden aspen mortality is supported by 21 studies.

\section{Climate Change and Herbivory}

Grazing and browsing in aspen ecosystems on the Uinta-Wasatch-Cache and Ashley NFs is by wildlife and domestic livestock. This over-browsing can reduce or even stop the successful regeneration of trees, especially when combined with drought, shallow soil depth, or hydrologic conditions such as high water tables (Johnston 2001; O'Brien et al. 2010). Monitoring data on the Ashley NF show that current aspen regeneration is abundant where domestic and wild ungulate (hoofed animal) grazing is ongoing, and aspen expansion is also indicated (fig. 18). In some instances, minor scale moderate to heavy ungulate grazing is impacting aspen regeneration (Goodrich and Huber 2015).

Other areas of Utah south and west of the Ashley NF are experiencing declines in tree regeneration as a result of over-browsing. For example, Rogers et al. (2015) found moderate to high elk herbivory had a negative influence on aspen stands of Wolf Creek Ranch in northwestern Utah, which is private land that borders the study area of this assessment. Regeneration of aspen was below replacement levels on one half of the study area (5,765 acres [2,333 ha] of aspen stands), and many aspen stands were reduced to nearly a single layer of aspen dominated by aging canopy trees (Rogers et al. 2015). Kay and Bartos (2000) found that aspen subjected to deer browsing failed to regenerate or had lower stem densities compared to plots that were protected by fencing on the Dixie and Fishlake National Forests in Utah. High elk populations and heavy aspen browsing in the drought-prone Tavaputs Plateau of eastern Utah was found to 

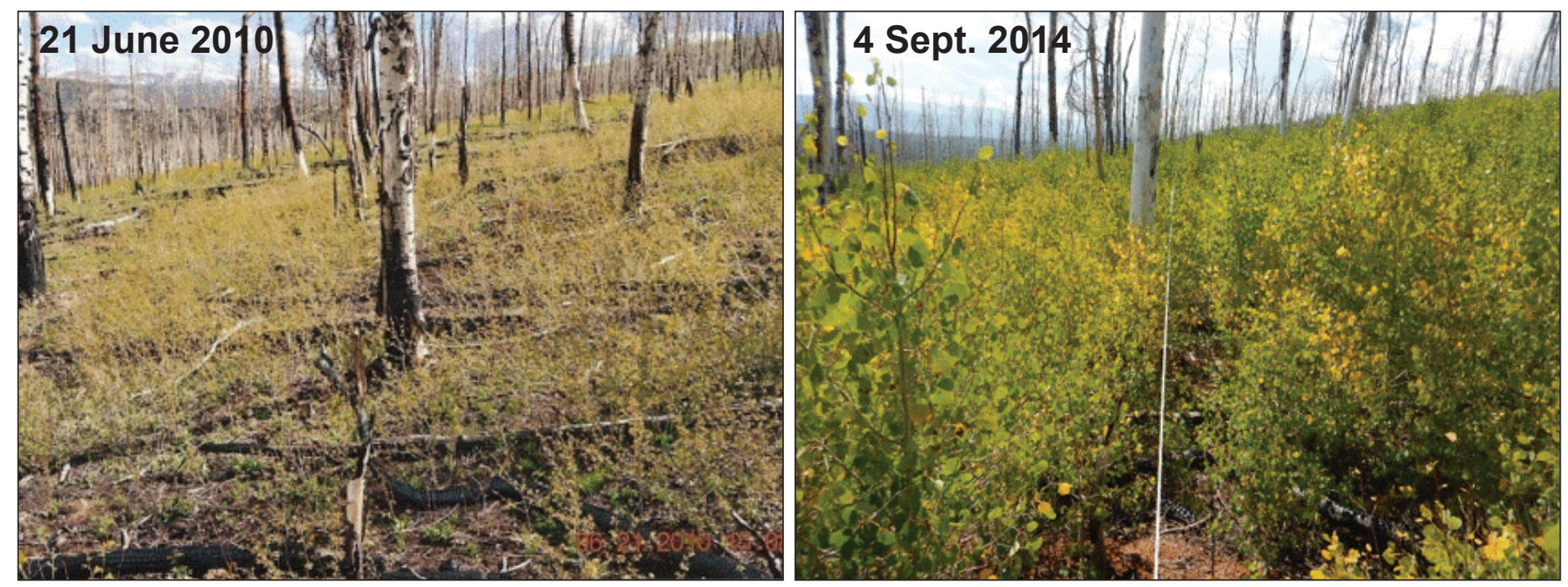

Figure 18-Dahlgren Creek on the Uinta-Wasatch-Cache National Forest. Photo on left: At year 2 post logging and burning, abundant aspen sprouts are about 1-2 feet tall. Sprouts of this size are vulnerable to ungulate browsing. Additional monitoring was needed to determine sustainability. Photo on right: At year 6 post logging and burning, canopy cover of aspen is about $60 \%$ and the average height of sprouts is about $6 \mathrm{ft}$. Cattle were permitted here each year since the 2008 burn. Sustainability of aspen concurrent with cattle and wild ungulate use is indicated (Zobell and Goodrich 2015).

reduce aspen regeneration as well, especially in pure aspen stands and in areas with flatter slopes (Rogers and Mittanck 2014). Martin and Maron (2012) found that less winter snowpack allowed more elk herbivory of aspen and contributed to aspen habitat deterioration and lower bird populations in Arizona. In some cases, however, the effects of current ungulate browsing are not definitively linked to a reduction or lack of aspen regeneration as Rogers et al. (2010) found on Cedar Mountain in southern Utah. They did not find clear evidence of current ungulate suppression of regeneration, but they did find unhealthy aspen stands in drought-prone areas. They suggested that land use history (including previous herbivory) altered disturbance regime, while soils and geology were factors influencing the aspen conditions in this area.

Grazing and aspen sucker or seedling browsing by the different types of grazing animals vary across landscapes over time and according to environmental condition. Wan et al. (2014) study across all Utah's National Forests found aspen regeneration benefitted from larger and more severe fires. Greater light availability in high severity fire sites was found to increase aspen growth and the defense chemistry against browsing. Aspen have a chemical defense system of phenolic glycosides in leaves, which deter insect and in some cases ungulate foraging. On the Fishlake National Forest, Utah, damage from browsing was 60 percent lower in moderate or high intensity burn areas compared to low intensity burns (Wan et al. 2014). Villalba et al. (2014) found that the availability of higher quality forage was a driving factor in the choice of what sheep graze. When the nutritional quality of grasses and forbs declined, aspen were grazed more heavily despite higher concentrations of chemical defenses. Jones et al. (2011) study in Lassen National Forest, California, found that cattle utilized understory meadow vegetation early in the growing season and shifted to aspen suckers by mid-season, while using aspen for forage mostly in the late growing season. 
How climate change may exacerbate the effects of grazing in aspen ecosystems depends on many factors: stand age structure, grazing and wildlife management, soil and hydrologic conditions, and the occurrence of drought. For example, if there is less snow on the ground and little forage available, herbivory of aspen may increase. A high vulnerability is assigned as climate change has a high potential of exacerbating deleterious effects of grazing and browsing in aspen ecosystems, but in some cases, management may partially offset these effects through reducing wildlife and cattle numbers, the season of grazing, or grazing intensity.

\section{Climate Change, Fire, and Bark Beetle Outbreaks}

\section{Fire}

Climate warming and drying have recently been observed to alter fire behavior. The last decade has seen a lengthening of the fire season, more frequent fires larger than 1,000 acres (405 ha), and burned areas that have become larger as compared to the 1970s and 1980s in the western United States (Dennison et al. 2014; Westerling et al. 2014). This upswing in fire activity has been attributed to warming, drying, earlier springs, and less snowpack (Westerling et al. 2014). Although their study time period was shorter, Dillon et al. (2011) found a statistically increasing trend in the annual area burned and area burned severely between 1984 and 2006 in the southern Rocky Mountains (including the Wasatch Range and Uinta Mountains), the Mogollon Rim, and the Colorado Plateau. The more important predictors of severe fire occurrence tended to be topographic variables, rather than climate or weather variables; however, when dry conditions prevailed, regional climatic controls appeared to overwhelm topographic effects (Dillon et al. 2011).

Aspen generally has a low fire potential when stands are healthy and have a lush understory. Most aspens on the Uinta-Wasatch-Cache and Ashley NFs have been modeled to have a very low or low potential for an intense fire that may be difficult to suppress (fig. 19) (U.S. Department of Agriculture 2013b). High fuel moisture content lowers burn risk, and can enable aspen forests to serve as fire breaks. Fires in conifer forests that move into aspen stands have been observed to drop to the ground and burn a short distance (Fechner and Barrows 1976). Aspen forests will burn, however, when low fuel moisture and fuel continuity are present. Downed wood, shrubs, and conifer presence in aspen stands can increase the chance of high severity fire and aspen mortality (Brown and Simmerman 1986). Persistent aspen stands without conifer presence are less susceptible to fire than stands with conifers present (Shinneman et al. 2013), and riparian aspen are the least susceptible to fire (O'Brien et al. 2010). DeRose and Leffler (2014)

modeled aspen fire behavior, which varied across different aspen stand composition and fire weather. Crowning and torching were not simulated to occur in aspen-dominated stands when there were moderate weather conditions. Crown fires occurred under severe and extreme fire weather, but not under moderate or high fire weather. Aspen trees are considered fire-adapted as they are early successional, being the first to 


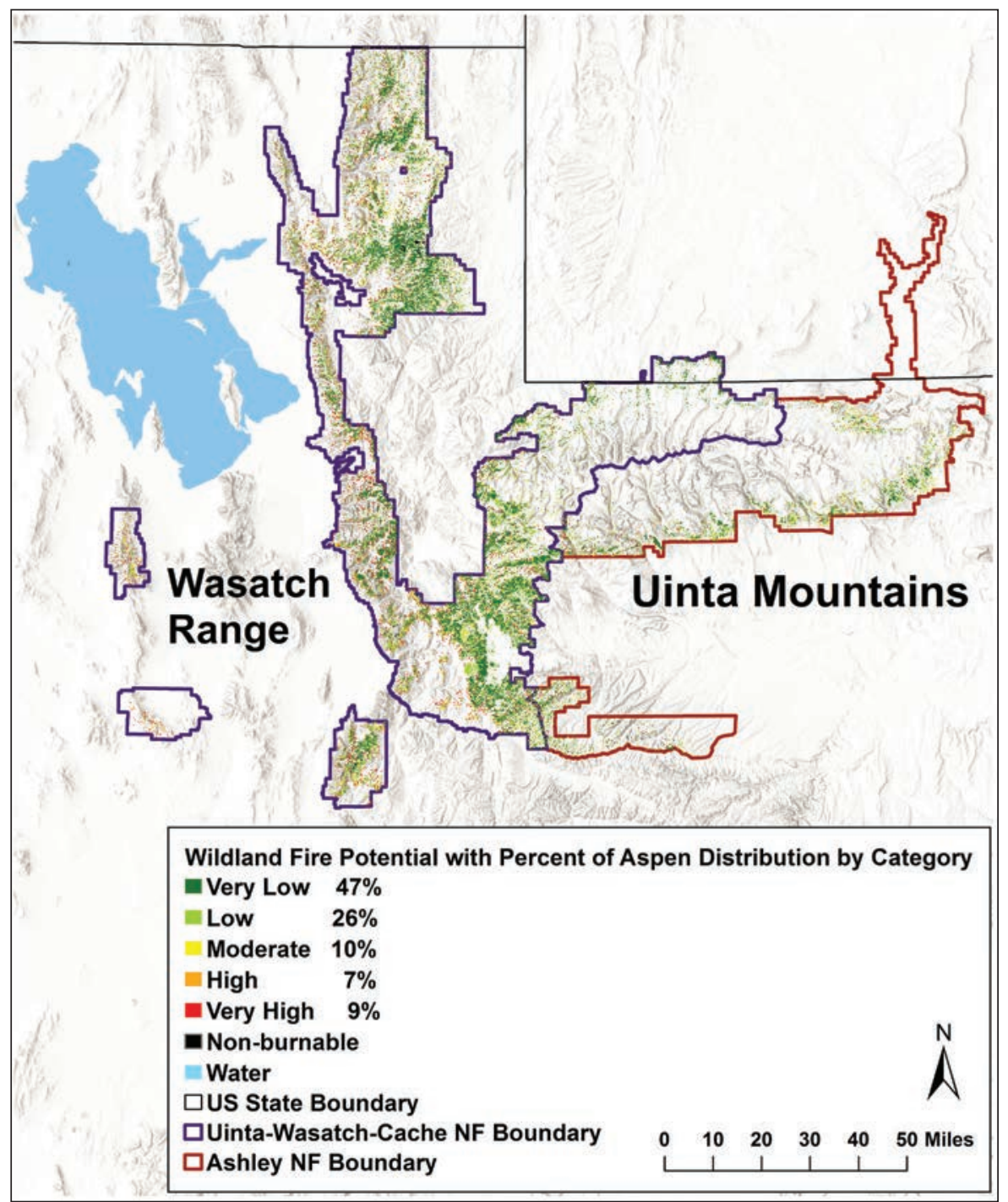

Figure 19-Wildland fire potential for aspen stands on the Uinta-Wasatch-Cache and Ashley National Forests, and the percent of total aspen extent by wildfire potential class is given in the legend. Higher fire potential has an elevated probability of experiencing high-intensity fire with torching, crowning, and other forms of extreme fire behavior under weather conditions conducive to fire (data from the Fire Modeling Institute, USDA 2013b).

regenerate, often prolifically after a fire, and sometimes by seed (Romme et al. 1997; Krasnow and Stephens 2015; Long and Mock 2012; Rogers et al. 2014). There are aspen stands that are relatively persistent and where fire is rare, especially when conifers are not present or where topographic or hydrologic conditions inhibit fire (Rogers et al. 2010). Most aspen stands require fire to persist because this disturbance opens the canopy allowing adequate light to promote regeneration (Shinneman et al. 2013).

Current and future fire disturbance regimes are likely to benefit aspen ecosystems, provided that ungulate herbivory pressure is low during the initial establishment or regeneration period. The potential increase in fire occurrence and size associated with climate change suggests an increased likelihood of aspen tree dominance in the future. Wan et al. (2014) found that increased fire size and severity had a positive effect on 
aspen regeneration in National Forests across Utah. They contend that future fire regimes with larger and more severe fires would have positive effects on aspen regeneration, assuming climate conditions and ungulate herbivory don't dampen the positive effects. Kulakowski et al. (2013b) study in northwestern Colorado subalpine forests asserted that increased dominance of aspen could reduce the probability and severity of future fire disturbance and increase the resilience of forests. As most aspen stands are dependent on fire and would be benefitted by increased frequency and extent, a low vulnerability is assigned to this criterion.

\section{Conifer Bark Beetle Outbreaks in Seral Aspen}

Conifer forests in the western United States have experienced large areas of mortality from bark beetle outbreaks as (a) warmer temperatures have reduced cold-induced bark beetle mortality, (b) drought stress has reduced tree defenses against bark beetles, and (c) fire suppression has created many mature forests susceptible to bark beetles (Bentz et al. 2009). Conifer mortality from future bark beetle outbreaks is expected to expand to higher latitudes and altitudes, although spatial and temporal variability of outbreaks is expected (Bentz et al. 2010).

How aspen may respond to conifer mortality from bark beetle outbreaks is a new area of scientific investigation. It is hypothesized that conifer mortality from bark beetles would result in a pulse of aspen recruitment as a result of competition release, if aspen are present within conifer stands. However, it remains unclear if this is the case, since many factors affect aspen regeneration: (a) surviving conifers may limit aspen regeneration by shading them, (b) new aspen suckers may be hindered by ungulate grazing, (c) canopy openings may expose aspen to severe weather that inhibits them, (d) they may be subjected to damage from falling snags, and (e) climate warming and drying may inhibit aspen sucker growth (Pelz and Smith 2013). Bretfeld et al. (2015) study of aspen in a severe bark beetle outbreak area of northern Colorado found increased radial growth of aspen but no change in aspen suckering as the release from conifer competition was dedicated to radial growth instead of suckering. Given the potential for bark beetle outbreaks to benefit aspen recruitment and growth, a low vulnerability is assigned to this criterion, but with the caveat that little scientific investigation has been completed as yet.

\section{Climate Change, Insects and Diseases, Sudden Aspen Mortality and Regeneration}

Sudden mortality of large areas of aspen trees was first noted by Worrall et al. (2008) in southwestern Colorado. The cause of this aspen mortality event has been associated with several physical and biological factors. Predominant factors such as multi-year severe drought and heat have been linked with the sudden mortality (Rehfeldt et al. 2009; Worrall et al. 2010, 2013). High density stands and presence of conifers have been used to explain patterns of mortality by the recent sudden aspen mortality events in the Intermountain West and Rocky Mountains (Bell et al. 2014) (also see Sensitivity to Drought section). 
Insects and disease can contribute to worsen the degree of sudden aspen mortality associated with drought and heat (Marchetti et al. 2011), thus the effects of climate warming and drying can be exacerbated. Primary agents that were attributed to increased damage and mortality of aspen during the early 2000s drought in Utah are: Cytospora canker, sooty bark canker, other unidentified cankers, Phellinus decay, bronze poplar borer, poplar borer, eastern poplar borer, poplar dicerca, and mechanical damage from animals (Guyon and Hoffman 2011). Damaging but not killing agents to aspen trees are: large aspen tortrix, aspen leaf tier, aspen two leaf tier, aphids, aspen leaf miner, blotch miners, leaf rollers, forest tent caterpillars, poplar petiole gall, mites, aspen skeletonizer, lace bugs, and leaf beetles (Guyon and Hoffman 2011; St. Clair et al. 2010). The leaf defoliating gypsy moth has been found in Utah but eradicated, with continuous monitoring showing it has not been present since 2008 (UDAF 2015). If the gypsy moth were present, potential future invasions modeled by Logan et al. (2007) showed an expansion of the moth into higher elevations of the Wasatch Range and Uinta Mountains where suitable climates are expected to develop.

The recent mortality of aspen across the western United States has been associated with multiple interacting factors of drought as well as insects and diseases (Kliejunas et al. 2009; Marchetti et al. 2011; St. Clair et al. 2010). While new invasive insects as well as already present ones threaten damage and mortality to aspen, the ability of aspen to quickly regenerate may offset deleterious effects. Given that aspen persist despite damage and mortality from insects and disease, a moderate vulnerability is assigned to this criterion.

\section{Likelihood of Managing or Alleviating Climate Change Effects}

Summary: There are numerous management options to mitigate stressors on aspen ecosystems and have the potential to reduce the effects of climate change, however, the effectiveness in mitigating future climate change is untested. Management actions can be overwhelmed by extreme conditions, and some options may not be feasible or are limited to the degree they can offset the effects of climate change. Climate adaptation is an area of further study and is an iterative process that requires long-term planning and monitoring. High vulnerability is assigned.

Information confidence:

- Management responses for aspen and adaptation are supported by 21 studies.

\section{Climate Change Adaptation}

Adaptation to climate change is a complex challenge, and a new and growing body of science has developed to support and guide adaptation to climate change (Moss et al. 2013). Developing and implementing climate adaptation options face the challenges of: limited financial resources available for management activity, conflicting social political values, and policy direction; and limited or unclear information to guide adaptation option development, such as multiple trajectories of future climate. 
The determination of success for climate adaptation actions are an area in need of further scientific study, and is defined by multiple objectives from economic, institutional, policy, ecological, social, and political viewpoints (Moser and Boykolf 2013). Doria et al. (2009) used expert elicitation to define successful adaptation to climate change as "any adjustment that reduces the risks associated with climate change, or vulnerability to climate change impacts, to a predetermined level, without compromising economic, social, and environmental sustainability." Few examples of successful climate change adaptation exist, while adaptation to past climate or non-climate stressors are numerous (Moser and Boykolf 2013). While the degree of climate adaptation effectiveness of management actions is an area of further study, numerous aspen management actions have been used to protect, maintain, and restore aspen ecosystems (table 3). These actions need careful consideration of management goals, the evaluation of effectiveness, learning by doing and sharing of best practices, and may need to apply methods in innovative ways to meet new challenges of future climate change (Bierbaum et al. 2013; Mawdsley et al. 2009). Despite the challenges of climate adaptation there is a strong call to develop climate adaptation science and implement actions that mitigate climate change (Moss et al. 2013). Climate adaptation is an iterative process that requires long-term planning and monitoring.

\section{Management Strategies}

Rogers (2015a) recommends a strategic approach to the management of aspen by incorporating the following: knowledge of aspen types (persistent, seral and mixed aspen-conifer, and riparian discussed in the Introduction), monitoring, historic disturbance, and collaborative problem-solving. Before management action is taken, Shepperd et al. (2006) recommend a careful investigation of size, age, vigor, and successional status of aspen clones. They also recommend consideration of soils, site productivity, competition from other plants, and the potential impact of browsing animals on new regeneration. Treatments may include doing nothing or using harvesting, prescribed fire, mechanical root stimulation, removal of competing vegetation, protection from herbivory, or in limited cases aspen seed regeneration (Long and Mock 2012). Bartos and Campbell (1998) outlined 5 risk factors for aspen decline in Utah as follows:

(1) Conifer under and over story cover is $>25$ percent.

(2) Aspen canopy cover is $<40$ percent.

(3) Dominant aspen trees are $>100$ years old.

(4) Aspen regeneration 5 to 15 feet tall is $<500$ stems/acre.

(5) Sagebrush cover is $>10$ percent. 
Within these parameters, O'Brien et al. (2010) recommended a four step process for the management of aspen. Although no guideline for aspen management can anticipate all situations, they offer general guidelines to think holistically in terms of aspen management. O'Brien et al. (2010) four step process is:

Step 1: Assess the condition of aspen in the landscape/area including the determination of the aspen type and significance of aspen in the project area.

- Is aspen a significant part of the diversity, composition, and function of the landscape? If yes, treatment may be warranted. Late successional forests that have converted to conifer dominance with scattered remnant aspen may need to be considered as well. These sites may have historically been dominated by aspen (Dale Bartos, U.S. Forest Service, personal communication, 2015).

- Is the trajectory for aspen without treatment to move outside of the sustainable conditions at the landscape level (for example, aerial cover, stand structure, stand composition, overstory/understory cover)? If yes, management changes or actions may be warranted.

Step 2: Rely on site-specific data to target the underlying cause(s) of problematic condition(s). See O’Brien et al. 2010.

Step 3: Select response options(s) relevant to the particular stand type, problematic condition(s), underlying causes of the problematic condition(s), and landscape context.

Step 4: Monitor.

- Monitoring should be consistent and implemented throughout the aspen restoration process.

A summary of potential management responses drawing on several literature sources are given in table 4 .

Table 4-Summary of possible management responses and goals. Compiled from O'Brien et al. (2010), Rogers et al. (2014), or other studies cited. Note: Combinations of responses are possible, or using more intensive responses as indicated by monitoring results.

\begin{tabular}{l}
\hline Reduce Stressors, Revitalize Existing Stands and Promote Aspen Recruitment \\
\hline Seral aspen types \\
\hline Cut subdominant conifers \\
\hline $\begin{array}{l}\text { Cutting of aspen and conifers. The amount of animal browsing needs to be considered as aspen regeneration may be con- } \\
\text { sumed, posing the risk of die-out of the aspen stand (Kay and Bartos 2000). Selective cutting may be a preferred option to } \\
\text { stimulate aspen regeneration. }\end{array}$ \\
\hline Burn aspen and conifers, or allow wildfires to burn and create new sites for aspen to occupy. Restore the natural fire regime. \\
\hline Selectively cut overstory conifers \\
Hinge trees to impede ungulate access (Kota and Bartos 2010) Note: O'Brien et al. (2010) report variable results with this treat- \\
ment and Walters et al. (1982) noted logging wounds predisposed aspen trees to insect and disease attacks. Using tracked \\
feller-bunchers to remove conifers can avoid excessive damage to existing trees. Damage from mechanical removal can delay \\
recruitment (Jones et al. 2005).
\end{tabular}




\section{Girdle conifers}

In conifer dominated stands, create scattered canopy gaps in conifer over story so the aspen component will persist over time in later successional forests.

\section{Persistent Aspen Types}

Restore structural diversity where absent (use vegetation treatments to simulate gap/phase dynamics). Rogers et al. (2014) note that terrain isolated persistent aspen types need little active management as long as ungulate over-browsing is not an issue.

Address a potential causes of a lapse in recruitment

Simulate gap/phase dynamics with vegetation manipulation, not large-scale and high severity disturbances

\section{Riparian Aspen Types}

Limit domestic browsing and other human activities where possible (Newlon and Saab 2011)

Careful mechanical harvest to restore aspen (Shepperd et al. 2006). For example, removal of unwanted trees in riparian areas.

\section{Grazing Management Responses}

Change the length and/or timing, class or number of livestock, or change the placement of salt and nutritional supplements. The nutritional value of aspen is higher in fall compared to others forage, and suckers may need protection during the fall (Shepperd et al. 2006).

Fence or temporarily fence to reduce livestock and/or wild ungulate pressure on aspen suckers

Rest excessively browsed aspen when fencing or changes in livestock grazing are not sufficient or feasible or when actions are needed across the landscape

Change annual browse utilization limits in grazing systems to ensure aspen sucker recruitment into the $>6$ foot height class. Improve and increase the availability of native vegetation for wildlife outside aspen stands of concern

\section{Recreation Management Responses}

Prevent or reduce dispersed camping within aspen

Post or sign dispersed camping in appropriate locations

\section{Monitor}

Monitor for successful regeneration of aspen. Also see Fowler (2014) study that discusses efficient distance method sampling routines, and Shepperd et al. (2006) study that discusses aspen monitoring and assessment techniques.

Monitor browsing level: 30 percent threshold suggested by Olmsted (1979) and a $20 \%$ threshold is suggested by Jones et al. (2005)

Monitor for signs of risk factors from Shepperd et al. (2006):

Conifer understory and overstory cover is $>25 \%$

Aspen cover is $<40 \%$

Dominant aspen trees are greater than 100 years old

Sagebrush cover is $>10 \%$

Aspen recruitment levels on stems $>6$ feet but less than the canopy height $<500 /$ acre is not self-replacing.

Aspen regeneration levels of suckers $<6 \mathrm{ft}$ in height: $>1000 / a c r e$ are self-replacing

$500-1000$ /acre is marginal

$<500$ /acre is not self-replacing

\section{Collaborate}

Use collaborative problem solving (Rogers 2015a)

\section{Climate Change and Sudden Aspen Mortality Responses}

Establish new stands in a climatically suitable habitat (Krasnow and Stephens 2015)

- Aspen root separation (Documented successful in some settings to increase the area covered by a clone)

- Outplant seedlings ${ }^{a}$, transplant ramets, disperse seeds to a suitable microclimate after disturbance

Sudden Aspen Mortality Management (Worrall et al. 2014)

- Use coppice cutting to promote the regeneration of stands with $<50 \%$ mortality, above $50 \%$ mortality has been shown to have little regeneration potential (Shepperd et al. 2015).

- Ensure there are significant patches of aspen trees $<40$ years old on the landscape as these trees are less susceptible to drought

- Classify aspen habitat by suitability of future climate. Facilitate migration to new areas where suitable climate exists.

- Improve resilience by reducing stressors (as listed above)

\footnotetext{
${ }^{a}$ Note: Outplanting aspen in the wild has been found not to be very successful in Steamboat Springs, Colorado. W. Shepperd found a $50 \%$ loss of
} plantings even though a drip irrigation system was going to each plant (Dale Bartos (2015) personal communication). 


\section{References}

Alberto, F.; Aitken, S.; Alia, R.; [et al.]. 2013. Potential for evolutionary responses to climate change evidence from tree populations. Global Change Biology. 19(6): 1645-1661. doi: 10.1111/gcb.12181.

Aldridge, G.; Inouye, D.; Forrest, J.; [et al.]. 2011. Emergence of a mid-season period of low floral resources in a montane meadow ecosystem associated with climate change. Journal of Ecology. 99(4): 905-913. doi: 10.1111/j.1365-2745.2011.01826.x.

Ally, D.; Ritland, K.; Otto, S. 2008. Can clone size serve as a proxy for clone age? An exploration using microsatellite divergence in Populus tremuloides. Molecular Ecology. 17(22): 4897-4911. doi: 10.1111/j.1365-294X.2008.03962.x.

Amberg, S.; Kilkus, K.; Sarah, G.; [et al.]. 2012. Badlands National Park climate change vulnerability assessment. Fort Collins, CO: U.S. Department of the Interior, National Park Service. 308 p.

Anderegg, W.; Anderegg, L.; Berry, J.; [et al.]. 2014. Loss of whole-tree hydraulic conductance during severe drought and multi-year forest die-off. Oecologia. 175(1): 11-23. doi: 10.1007/s00442-013-2875-5.

Anderegg, W.; Anderegg, L.; Sherman, C.; [et al.]. 2012a. Effects of widespread drought-induced aspen mortality on understory plants. Conservation Biology. 26(6): 1082-1090. doi: 10.1111/j.1523-1739.2012.01913.x.

Anderegg, W.; Berry, J.; Smith, D.; [et al.]. 2012b. The roles of hydraulic and carbon stress in a widespread climate-induced forest die-off. Proceedings of the National Academy of Sciences of the United States of America. 109(1): 233-237. doi: 10.1073/pnas.1107891109.

Anderegg, W.; Flint, A.; Huang, C.; [et al.]. 2015. Tree mortality predicted from drought-induced vascular damage. Nature Geoscience. 8: 367-371. doi: 10.1038/ NGE02400.

Ashley NF. 2014a. Bird Surveys (1994-1995). Unpublished data on file with: U.S. Department of Agriculture, Forest Service, Ashley National Forest, Vernal, UT.

Ashley NF. 2014b. Goshawk monitoring data (1991-2014). Unpublished data on file with: U.S. Department of Agriculture, Forest Service Ashley National Forest, Vernal, UT.

Ault, T.; Cole, J.; Overpeck, J.; [et al.]. 2014. Assessing the risk of persistent drought using climate model simulations and paleoclimate data. Journal of Climate. 27(20): 7529-7549. doi: 10.1175/JCLI-D-12-00282.1.

Bartos, D. 2000. Landscape dynamics of aspen and conifer forests. In: Sheppherd, W.D.; Binkley, D.; Bartos, D.; [et al.], eds. Sustaining aspen in western landscapes. Symposium Proceedings; 2000 June 13-15. Grand Junction, Colorado. Proc. RMRS-P-18. U.S. Departmebnt of Agriculture, Forest Service, Rocky Mountain Research Station: 5-14.

Bartos, D.; Campbell, R.J. 1998. Decline of quaking aspen in the interior west: Examples from Utah. Rangelands. 20(1): 17-24.

Bates, P.; Sucoff, E.; Blinn, C. 1998. Short-term flooding effects on root suckering of aspen. Northern Journal of Applied Forestry. 15(4): 169-173. 
Bekker, M.; DeRose, R.; Buckley, B.; [et al.]. 2014. A 576-year Weber River streamflow reconstruction from tree rings for water resource risk assessment in the Wasatch Front, Utah. Journal of the American Water Resources Association. 50(5): 1338-1348. doi: 10.1111/jawr.12191.

Bell, D.; Bradford, J.; Lauenroth, W. 2014. Forest stand structure, productivity, and age mediate climatic effects on aspen decline. Ecology. 95(8): 2040-2046.

Bentz, B., ed. 2009. Bark beetle outbreaks in western North America: Causes and consequences. Bark beetle symposium; 2005 November 15-18; Snowbird, UT. Salt Lake City, UT: University of Utah Press: 42 p.

Bentz, B.; Regniere, J.; Fettig, C.; [et al.]. 2010. Climate change and bark beetles of the western United States and Canada: Direct and indirect effects. Bioscience. 60(8): 602-613. doi: 10.1525/bio.2010.60.8.6.

Bierbaum, R.; Smith, J.; Lee, A.; [et al.]. 2013. A comprehensive review of climate adaptation in the United States: More than before, but less than needed. Mitigation and Adaptation Strategies For Global Change. 18(3): 361-406. doi: 10.1007/ s11027-012-9423-1.

Bretfeld, M.; Doerner, J.; Franklin, S. 2015. Radial growth response and vegetative sprouting of aspen following release from competition due to insect-induced conifer mortality. Forest Ecology and Management. 347: 96-106.

Brown, J.; Simmerman, D. 1986. Appraising fuel and flammability in western aspen: A prescribed fire guide. Gen. Tech. Rep. INT-205. Ogden, UT. U.S. Department of Agriculture, Forest Service, Intermountain Research Station. 52 p.

Buck, J.; St. Clair, S. 2012. Aspen increase soil moisture, nutrients, organic matter and respiration in Rocky Mountain forest communities. Plos One. 7(12): e52369. doi: 10.1371/journal.pone.0052369.

Buell, M.F.; Buell, H.F. 1959. Aspen invasion of prairie. Bulletin of the Torrey Botanical Club. 86(4): 264-265.

Burke, A.; Kasahara, T. 2011. Subsurface lateral flow generation in aspen and coniferdominated hillslopes of a first order catchment in northern Utah. Hydrological Processes. 25(9): 1407-1417. doi: 10.1002/hyp.7906.

Calder, W.; St. Clair, S. 2012. Facilitation drives mortality patterns along succession gradients of aspen-conifer forests. Ecosphere. 3(6): 1-11. doi: 10.1890/ ES12-00119.1.

Calder, W.; Horn, K.; St. Clair, S. 2011. Conifer expansion reduces the competitive ability and herbivore defense of aspen by modifying light environment and soil chemistry. Tree Physiology. 31(6): 582-591. doi: 10.1093/treephys/tpr041.

Callahan, C.; Rowe, C.; Ryel, R.; [et al.]. 2013. Continental-scale assessment of genetic diversity and population structure in quaking aspen (Populus tremuloides). Journal of Biogeography. 40(9): 1780-1791. doi: 10.1111/jbi.12115.

Carson, E. 2007. Temporal and seasonal trends in strearnflow in the Uinta Mountains, northeastern Utah, and relation to climatic fluctuations. Arctic Antarctic and Alpine Research. 39(4): 521-528. doi: 10.1657/1523-0430(06-072)[CARSON]2.0.CO;2. 
Carson, E.; Munroe, J. 2005. Tree-ring based streamflow reconstruction for Ashley Creek, northeastern Utah: Implications for palaeohydrology of the southern Uinta Mountains. Holocene. 15(4): 602-611. doi: 10.1191/0959683605h1835rp.

Carter, J.; Chard, B. 2011. Moderating livestock grazing effects on plant productivity, nitrogen and carbon storage. Natural Resources and Environmental Issues. 17: Article 23. http://digitalcommons.usu.edu/nrei/vol17/iss1/23.

Chong, G.W.; Simonson, S.E.; Stohlgren, T.J.; [et al.]. 2001. Biodiversity: Aspen stands have the lead, but will nonnative species take over? In: Shepperd, W.D.; Binkley, D.; Bartos, D.L.; [et al.], comps. Sustaining aspen in western landscapes: Symposium proceedings. Proc. RMRS-P-18. Fort Collins, CO: U.S. Department of Agriculture, Forest Service, Rocky Mountain Research Station: 261-272.

Christensen, N.; Lettenmaier, D. 2007. A multimodel ensemble approach to assessment of climate change impacts on the hydrology and water resources of the Colorado River Basin. Hydrology and Earth System Sciences. 11(4): 1417-1434.

Cook, B.; Ault, T.; Smerdon, J. 2015. Unprecedented 21st century drought risk in the American Southwest and Central Plains. Science Advances. 1(1): e1400082.

Cornell Lab of Ornithology. 2014. State of the birds, maps and species list. Website produced for U.S. Fish and Wildlife Service by Cornell Lab of Ornithology. http:// www.stateofthebirds.org/2014/maps_species.

Cottam, W.P. 1954. Prevernal leafing of aspen in Utah mountains. Journal of the Arnold Arboretum. 35(3): 239-250.

Cryer, D.H.; Murray, J.E. 1992. Aspen regeneration and soils. Rangelands. 14(4): 223-226.

DeByle, N. 1985a. Animal impacts. In: Aspen: Ecology and management in the Western United States. Gen. Tech. Rep. RM-119. Fort Collins, CO: U.S. Department of Agriculture, Forest Service, Rocky Mountain Forest and Range Experiment Station: $115-123$.

DeByle, N. 1985b. Water and Watersheds. In: Aspen: Ecology and management in the western United States. Gen. Tech. Rep. RM-119. Fort Collins, CO. U.S. Department of Agriculture, Forest Service, Rocky Mountain Forest and Range Experiment Station: $153-160$.

DeByle, N. 1985c. Wildlife. In: Aspen: Ecology and management in the western United States. Gen. Tech. Rep. RM-119. Fort Collins, CO. U.S. Department of Agriculture, Forest Service, Rocky Mountain Forest and Range Experiment Station: 135-152.

DeByle, N.V. 1981. Songbird populations and clearcut harvesting of aspen in northern Utah. Res. Note INT-302. Ogden, UT: U.S. Department of Agriculture, Forest Service, Intermountain Forest and Range Experiment Station. 7 p.

Dennison, P.; Brewer, S.; Arnold, J.; [et al.]. 2014. Large wildfire trends in the western United States, 1984-2011. Geophysical Research Letters. 41(8): 2928-2933. doi: 10.1002/2014GL059576.

DeRose, R.; Leffler, A. 2014. Simulation of quaking aspen potential fire behavior in northern Utah, USA. Forests. 5(12): 3241-3256. doi: 10.3390/f5123241. 
DeRose, R.; Bekker, M.; Wang, S.; [et al.]. 2015. A millennium-length reconstruction of Bear River stream flow, Utah. Journal of Hydrology. 529(2): 524-534. dx.doi. org/10.1016/j.jhydrol.2015.01.014

DesRochers, A.; Lieffers, V. 2001. The coarse-root system of mature Populus tremuloides in declining stands in Alberta, Canada. Journal of Vegetation Science. 12(3): 355-360. doi: 10.2307/3236849.

DeWoody, J.; Rowe, C.; Hipkins, V.; [et al.]. 2008. "Pando" lives: Molecular genetic evidence of a giant aspen clone in central Utah. Western North American Naturalist. 68(4): 493-497. doi: 10.3398/1527-0904-68.4.493.

Dillon, G.; Holden, Z.; Morgan, P.; [et al.]. 2011. Both topography and climate affected forest and woodland burn severity in two regions of the western US, 1984 to 2006. Ecosphere. 2(12): 1-33. doi: 10.1890/ES11-00271.1.

Doria, M.; Boyd, E.; Tompkins, E.; [et al.]. 2009. Using expert elicitation to define successful adaptation to climate change. Environmental Science \& Policy. 12(7): 810-819. doi: 10.1016/j.envsci.2009.04.001.

Edworthy, A.; Drever, M.; Martin, K. 2011. Woodpeckers increase in abundance but maintain fecundity in response to an outbreak of mountain pine bark beetles. Forest Ecology and Management. 261(2): 203-210. doi: 10.1016/j.foreco.2010.10.006.

Endress, B.; Wisdom, M.; Vavra, M.; [et al.]. 2012. Effects of ungulate herbivory on aspen, cottonwood, and willow development under forest fuels treatment regimes. Forest Ecology and Management. 276: 33-40. doi: 10.1016/j.foreco.2012.03.019.

Evans, D.M. 2010. A spatiotemporal analysis of aspen decline in southern Utah's Cedar Mountain, using remote sensing and geographic information systems. Thesis. Logan: Utah State University. 185 p.

Fechner, G.; Barrows, J. 1976. Aspen stands as wildfire fuel breaks. Eisenhower Consortium Bulletin 4. Fort Collins, CO: U.S. Department of Agriculture, Forest Service, Rocky Mountain Forest and Range Experimental Station. 26 p.

Forrest, J. 2015. Plant-pollinator interactions and phenological change: What can we learn about climate impacts from experiments and observations? Oikos. 124(1): 4-13. doi: 10.1111/oik.01386.

Forrest, J.; Thomson, J. 2011. An examination of synchrony between insect emergence and flowering in Rocky Mountain meadows. Ecological Monographs. 81(3): 469-491. doi: 10.1890/10-1885.1.

Franks, S.; Weber, J.; Aitken, S. 2014. Evolutionary and plastic responses to climate change in terrestrial plant populations. Evolutionary Applications. 7(1): 123-139. doi: 10.1111/eva.12112.

Gezon, Z.; Inouye, D.W.; Irwin, R.E. 2016. Phenological change in a spring ephemeral: Implications for pollination and plant reproduction. Global Change Biology. 22(5): 1779-1793. doi: 10.1111/gcb.13209.

Gifford, G.; Humphries, W.; Jaynes, R. 1984. A preliminary quantification of the impacts of aspen to conifer succession on water yield. 2. Modeling results. Water Resources Bulletin. 20(2): 181-186. 
Gillies, R.; Wang, S.; Booth, M. 2012. Observational and synoptic analyses of the winter precipitation regime change over Utah. Journal of Climate. 25(13): 46794698. doi: 10.1175/JCLI-D-11-00084.1.

Glick, P.; Stein, B.A.; Edelson, N.A. 2011. Scanning the conservation horizon: A guide to climate change vulnerability assessment. Washington, DC: National Wildlife Federation.

Goodrich, S.; Huber, A. 2015. Assessment of aspen sustainability Ashley National Forest and Evanston-Mtn. View Districts, Uinta-Wasatch-Cache National Forest. Unpublished document on file with: U.S. Department of Agriculture, Forest Service, Ashley National Forest, Vernal, UT.

Gray, L.; Hamann, A. 2013. Tracking suitable habitat for tree populations under climate change in western North America. Climatic Change. 117(1-2): 289-303. doi: 10.1007/s10584-012-0548-8.

Greene, J. 1971. Clonal variation in Populus tremuloides (Michx.) on the east slope of the Front Range, Boulder County, Colorado. Aspen Bibliography. Paper 5539.

Griffis-Kyle, K.; Beier, P. 2003. Small isolated aspen stands enrich bird communities in southwestern ponderosa pine forests. Biological Conservation. 110(3): 375-385. doi: 10.1016/S0006-3207(02)00237-9.

Guyon, J.; Hoffman, J. 2011. Survey of aspen dieback in the Intermountain Region. R4OFO-Report 11-01. Golden, CO: U.S. Department of Agriculture, Forest Service, Intermountain Region, Forest Health Protection. 20 p.

Hinds, T. 1985. Insects. In: Aspen: Ecology and management in the western United States. Gen. Tech. Rep. RM-119. Fort Collins, CO: U.S. Department of Agriculture, Forest Service, Rocky Mountain Forest and Range Experiment Station: 87-106.

Hogg, E.; Brandt, J.; Michaellian, M. 2008. Impacts of a regional drought on the productivity, dieback, and biomass of western Canadian aspen forests. Canadian Journal of Forest Research. 38(6): 1373-1384. doi: 10.1139/X08-001.

Howard, J. 1996. Populus tremuloides. In: Fire Effects Information System, [Online database]. Missoula, MT: U.S. Department of Agriculture, Forest Service, Rocky Mountain Research Station, Fire Sciences Laboratory. http://www.fs.fed.us/database/ feis/.

Iler, A.; Inouye, D.; Hoye, T.; [et al.]. 2013. Maintenance of temporal synchrony between syrphid flies and floral resources despite differential phenological responses to climate. Global Change Biology. 19(8): 2348-2359. doi: 10.1111/gcb.12246.

Inouye, D. 2008. Effects of climate change on phenology, frost damage, and floral abundance of montane wildflowers. Ecology. 89(2): 353-362. doi: 10.1890/06-2128.1.

Intergovernmental Panel on Climate Change (IPCC). 2014. Summary for policymakers. In: Field, C.B.; Barros, V.R.; Dokken, V.R.; [et al.], eds. Climate change 2014: Impacts, adaptation, and vulnerability. Part A: Global and sectoral aspects. Contribution of Working Group II to the Fifth Assessment Report of the Intergovernmental Panel on Climate Change. Cambridge, UK: Cambridge University Press. 32 p. 
Johnston, B. 2001. Multiple factors affect aspen regeneration on the Uncompahgre Plateau, west-central Colorado. Aspen Bibliography. Paper 658.

Jones, B.; Burton, D.; Tate, K. 2005. Effectiveness monitoring of aspen regeneration on managed rangelands: A monitoring method for determining if management objectives are being met in aspen communities. Vallejo, CA: U.S. Department of Agriculture, Forest Service, Pacific Southwest Region. 19 p.

Jones, B.; Lile, D.; Tate, K. 2011. Cattle selection for aspen and meadow vegetation: Implications for restoration. Rangeland Ecology \& Management. 64(6): 625-632. doi: 10.2111/REM-D-10-00089.1.

Jones, B.; Rickman, T.; Vazquez, A.; [et al.]. 2005. Removal of encroaching conifers to regenerate degraded aspen stands in the Sierra Nevada. Restoration Ecology. 13(2): 373-379. doi: 10.1111/j.1526-100X.2005.00046.x.

Jones, J.; DeByle, N. 1985a. Climate. In: Aspen: Ecology and management in the western United States. Gen. Tech. Rep. RM-119. Fort Collins, CO. U.S. Department of Agriculture, Forest Service, Rocky Mountain Forest and Range Experiment Station: $57-64$.

Jones, J.; DeByle, N. 1985b. Morphology. In: Aspen: Ecology and management in the United States. Gen. Tech. Rep. RM-119. Fort Collins, CO. U.S. Department of Agriculture, Forest Service, Rocky Mountain Forest and Range Experiment Station: $11-18$.

Jones, J.; Trujillo, D. 1975. Development of some young aspen stands in Arizona. Res. Pap. RM-151. Fort Collins, CO: U.S. Department of Agriculture, Forest Service, Rocky Mountain Forest and Range Experimental Station. 11 p.

Jones, J.; Kaufmann, M.; Richardson, E. 1985. Effects of water and temperature. In: Aspen: Ecology and management in the western United States. Gen. Tech. Rep. RM-119. Fort Collins, CO. U.S. Department of Agriculture, Forest Service, Rocky Mountain Forest and Range Experiment Station: 71-76.

Jones, L.; Horel, J. 2008. Assessing the sensitivity of Wasatch Mountain winter precipitation to present climate temperature variations. In: 17th Conference on Applied Climatology; 2008 August 11-15; Whistler, BC. Boston, MA: American Meterological Society: 47-55.

Julander, R.; Clayton, J. 2014. Discussion of influences on snow water equivalent at Utah Snow Courses. NRCS Snow Survey Technical Report. Salt Lake City, UT: National Resources Conservation Service. 34 p. http://www.nrcs.usda.gov/wps/ portal/nrcs/detail/ut/snow/?cid=nrcs141p2_034206.

Kashian, D.; Romme, W.; Regan, C. 2007. Reconciling divergent interpretations of quaking aspen decline on the northern Colorado Front Range. Ecological Applications. 17(5): 1296-1311. doi: 10.1890/06-1431.1.

Kay, C.; Bartos, D. 2000. Ungulate herbivory on Utah aspen: Assessment of long-term exclosures. Journal of Range Management. 53(2): 145-153. doi: 10.2307/4003274.

Kemperman, J.; Barnes, B. 1976. Clone size in American aspens. Canadian Journal of Botany. 54(22): 2603-2607.

Kliejunas, J.; Geils, B.; Glaeser, J.; [et al.]. 2009. Review of literature on climate change and forest diseases of western North America. Gen. Tech. Rep. 
PSW-GTR-225. Albany, CA: U.S. Department of Agriculture, Forest Service, Pacific Southwest Research Station. 54 p.

Klos, P.; Link, T.; Abatzoglou, J. 2014. Extent of the rain-snow transition zone in the western US under historic and projected climate. Geophysical Research Letters. 41(13): 4560-4568. doi: 10.1002/2014GL060500.

Korb, J. 2012. Predisposing and contributing factors associated with aspen mortality and the effects of Sudden Aspen Decline on ecological attributes, southwestern Colorado, USA. Fort Collins, CO: Colorado State University, Colorado Forest Restoration Institute. 47 p. https://cfri.colostate.edu/wp-content/uploads/2016/05/2012_Aspen_ Manuscript_Korb.pdf

Korb, J.; Bombaci, S.; Siegel, R. 2014. The effect of sudden aspen decline on understory microclimate and vegetation in southwestern Colorado. Canadian Journal of Forest Research. 44(8): 914-921. doi: 10.1139/cjfr-2014-0087.

Krasnow, K.; Stephens, S. 2015. Evolving paradigms of aspen ecology and management: Impacts of stand condition and fire severity on vegetation dynamics. Ecosphere. 6(1): Article 12.

Kulakowski, D.; Kaye, M.; Kashian, D. 2013a. Long-term aspen cover change in the western US. Forest Ecology and Management. 299: 52-59. doi: 10.1016/j. foreco.2013.01.004.

Kulakowski, D.; Matthews, C.; Jarvis, D.; [et al.]. 2013b. Compounded disturbances in sub-alpine forests in western Colorado favour future dominance by quaking aspen (Populus tremuloides). Journal of Vegetation Science. 24(1): 168-176. doi: 10.1111/j.1654-1103.2012.01437.x.

Kulakowski, D.; Veblen, T.; Kurzel, B. 2006. Influences of infrequent fire, elevation and pre-fire vegetation on the persistence of quaking aspen (Populus tremuloides Michx.) in the Flat Tops area, Colorado, USA. Journal of Biogeography. 33(8): 1397-1413. doi: 10.1111/j.1365-2699.2006.01529.x.

Kunkel, K.; Stevens, L.; Stevens, S.; [et al.]. 2013. Regional climate trends and scenarios for the U.S. National Climate Assessment Part 5. Climate of the Southwest U.S. NOAA Technical Report NEDIS 142-5. Wasington, DC: U.S. Department of Commerce, National Oceanic and Atmospheric Administration National Environmental Satellite, Data, and Information Service. 87 p.

LaMalfa, E.; Ryle, R. 2008. Differential snowpack accumulation and water dynamics in aspen and conifer communities: Implications for water yield and ecosystem function. Ecosystems. 11(4): 569-581. doi: 10.1007/s10021-008-9143-2.

Landhausser, S.; Deshaies, D.; Lieffers, V. 2010. Disturbance facilitates rapid range expansion of aspen into higher elevations of the Rocky Mountains under a warming climate. Journal of Biogeography. 37(1): 68-76. doi: 10.1111/j.1365-2699.2009.02182.x.

Lieffers, V.J.; Landhausser, S.M.; Hogg, E.H. 2001. Is the wide distribution of aspen a result of its greater stress tolerance? In: Sheppers, W.D.; Binkley, D.; Bartos, D.L.; [et al.], eds. Sustaining aspen in western landscapes: Symposium proceedings; 2000 June 13-15; Grand Junction, CO. Proceedings RMRS-P-18. Fort Collins, CO: U.S. Department of Agriculture, Forest Service, Rocky Mountain Research Station: 311-323. http://www.cfs.nrcan.gc.ca/pubwarehouse/pdfs/18532.pdf. 
Little, E. 1971. Atlas of United States trees. Volume 1: Conifers and important hardwoods. Miscell. Publ. 1146. Washington, DC: U.S. Department of Agriculture, Forest Service.

Logan, J.; Regniere, J.; Gray, D.; [et al.]. 2007. Risk assessment in the face of a changing environment: Gypsy moth and climate change in Utah. Ecological Applications. 17(1): 101-117. doi: 10.1890/1051-0761(2007)017[0101:RAITFO]2.0 .CO;2.

Long, J.; Mock, K. 2012. Changing perspectives on regeneration ecology and genetic diversity in western quaking aspen: Implications for silviculture. Canadian Journal of Forest Research. 42(12): 2011-2021. doi: 10.1139/x2012-143.

Lukas, J.; Barsugli, J.; Doesken, N.; [et al.]. 2014. Climate change in Colorado: A synthesis report to support water resource management and adaptation. A report for the Colorado Water Conservation Board. Boulder, CO: Western Water Assessment. $114 \mathrm{p}$.

MacDonald, G.; Tingstad, A. 2007. Recent and multicentennial precipitation variability variability and drought occurrence in the Uinta Mountains region, Utah. Arctic Antarctic and Alpine Research. 39(4): 549-555. doi: 10.1657/1523-0430(06-070) [MACDONALD]2.0.CO;2.

Manomet. 2010. Climate change and Massachusetts fish and wildlife: Volume 2 habitat and species vulnerability. Manomet, MA: Manomet Center for Conservation Science; Boston, MA: Massachusetts Department of Fish and Game. 59 p. https://www.manomet.org/sites/default/files/publications_and_tools/Climate $\% 20$ Change $\% 20$ and $\% 20$ Massachusetts $\% 20$ Fisheries $\% 20$ and $\% 20$ Wildlife $\% 20$ Reports\%2C\%20Vol.\%202\%20April\%202010.pdf

Manomet. 2012. The vulnerabilities of fish and wildlife habitats in the northeast to climate change: A report to the Northeast Association of Fish and Wildlife Agencies and the North Atlantic Landscape Conservation Cooperative. Manomet, MA: Manomet Center for Conservation Science; Merrifield, VA: National Wildlife Federation. $183 \mathrm{p}$.

Marchetti, S.; Worrall, J.; Eager, T. 2011. Secondary insects and diseases contribute to sudden aspen decline in southwestern Colorado, USA. Canadian Journal of Forest Research. 41(12): 2315-2325. doi: 10.1139/X11-106.

Martin, T.; Maron, J. 2012. Climate impacts on bird and plant communities from altered animal-plant interactions. Nature Climate Change. 2(3): 195-200. doi: 10.1038/NCLIMATE1348.

Matter, S.; Doyle, A.; Illerbrun, K.; [et al.]. 2011. An assessment of direct and indirect effects of climate change for populations of the Rocky Mountain Apollo butterfly (Parnassius smintheus Doubleday). Insect Science. 18(4): 385-3-92. doi: 10.1111/j.1744-7917.2011.01407.x.

Maurer, E.; Brekke, L.; Pruitt, T.; PB, D. 2007. Fine-resolution climate projections enhance regional climate change impact studies. EOS, Transactions American Geophysical Union. 88(47): 504-504.

Mawdsley, J.; O'Malley, R.; Ojima, D. 2009. A review of climate-change adaptation strategies for wildlife management and biodiversity conservation. Conservation Biology. 23(5): 1080-1089. doi: 10.1111/j.1523-1739.2009.01264.x. 
McDonough, W. 1985. Sexual reproduction, seeds and seedlings. In: Aspen: Ecology and management in the western United States. Gen. Tech. Rep. RM-119. Fort Collins, CO. U.S. Department of Agriculture, Forest Service, Rocky Mountain Research Station: 25-28.

Mock, K.; Rowe, C.; Hooten, M.; [et al.]. 2008. Clonal dynamics in western North American aspen (Populus tremuloides). Molecular Ecology. 17(22): 4827-4844. doi: 10.1111/j.1365-294X.2008.03963.x.

Moser, S.; Boykolf, M. 2013. Climate change and adaptation success. Successful adaptation to climate change: Linking science and policy in a rapidly changing world. London: Routledge. 336 p.

Moss, R.; Meehl, G.; Lemos, M.; [et al.]. 2013. Hell and high water: Practice-relevant adaptation science. Science. 342(6159): 696-698. doi: 10.1126/science.1239569.

Mote, P. 2006. Climate-driven variability and trends in mountain snowpack in western North America. Journal of Climate. 19(23): 6209-6220. doi: 10.1175/JCLI3971.1.

Mote, P.; Hamlet, A.; Clark, M.; [et al.]. 2005. Declining mountain snowpack in western north America. Bulletin of the American Meteorological Society. 86(1): 39-49. doi: 10.1175/BAMS-86-1-39.

Mueggler, W. 1985a. Forage. In: Aspen: Ecology and management in the western United States. Gen. Tech. Rep. RM-119. Fort Collins, CO. U.S. Department of Agriculture, Forest Service, Rocky Mountain Forest and Range Exeriment Station: 129-134.

Mueggler, W.F. 1985b. Vegetation associations. In: Aspen: Ecology and management in the western United States. Gen. Tech. Rep. RM-119. Fort Collins, CO. U.S. Department of Agriculture, Forest Service, Rocky Mountain Forest and Range Exeriment Station: 45-55 p.

National Oceanic and Atmospheric Administration (NOAA). 2008. What is drought? Drought Public Fact Sheet: May 2008. Silver Spring, MD: U.S. Department of Commerce, National Oceanic and Atmospheric Administration, National Weather Service. 3 p. http://www.nws.noaa.gov/os/brochures/climate/DroughtPublic2.pdf.

Neely, B.; Rondeau, R.; Sanderson, J.; [et al.]. 2012. Gunnison Basin: Vulnerability assessment for the Gunnison Climate Working Group. Boulder, CO: The Nature Conservancy, Colorado Natural Heritage Program, Western Water Assessment, University of Colorado; Fairbanks: University of Alaska. Project of the Southwest Climate Change Initiative. $262 \mathrm{p}$.

Norris, A.; Drever, M.; Martin, K. 2013. Insect outbreaks increase populations and facilitate reproduction in a cavity-dependent songbird, the Mountain Chickadee Poecile gambeli. Ibis. 155(1): 165-176. doi: 10.1111/ibi.12005.

O’Brien, M.; Rogers, P.; Mueller, K.; [et al.]. 2010. Guidelines for aspen restoration on the national forests in Utah. Logan, UT: Utah State University, Utah Forest Restoration Working Group - Ecology Committee, Western Aspen Alliance. 48 p.

Pelz, K.; Smith, F. 2013. How will aspen respond to mountain pine beetle? A review of literature and discussion of knowledge gaps. Forest Ecology and Management. 299: 60-69. doi: 10.1016/j.foreco.2013.01.008. 
Perala, D. 1990. Quaking aspen (Populus tremuloides Michx.). In: Burnes, R.M.; Honkala, B.H., tech. coords. Silvics of North America II. Deciduous. Agric. Handb. 654. U S. Department of Agriculture, Forest Service: 555-569.

Rasmont, P.; Iserbyt, S. 2012. The bumblebees scarcity syndrome: Are heat waves leading to local extinctions of bumblebees (Hymenoptera: Apidae: Bombus)? Annales De La Societe Entomologique De France. 48(3-4): 275-280.

Reclamation. 2014. Downscaled CMIP3 and CMIP5 climate and hydrology projections: Release of hydrology projections, comparison with preceding information, and summary of user needs. Denver, CO: U.S. Department of the Interior, Bureau of Reclamation, Technical Services Center. $110 \mathrm{p}$.

Regonda, S.; Rajagopalan, B.; Clark, M.; [et al.]. 2005. Seasonal cycle shifts in hydroclimatology over the western United States. Journal of Climate. 18(2): 372 384. doi: 10.1175/JCLI-3272.1.

Rehfeldt, G.; Crookston, N.; Warwell, M.; [et al.]. 2006. Empirical analyses of plantclimate relationships for the western United States. International Journal of Plant Sciences. 167(6): 1123-1150. doi: 10.1086/507711. http://forest.moscowfsl.wsu.edu/ climate/species/index.php.

Rehfeldt, G.; Ferguson, D.; Crookston, N. 2009. Aspen, climate, and sudden decline in western USA. Forest Ecology and Management. 258(11): 2353-2364. doi: 10.1016/j.foreco.2009.06.005.

Rehfeldt, G.; Worrall, J.; Marchetti, S.; [et al.]. 2015. Adapting forest management to climate change using bioclimate models with topographic drivers. Forestry. 88(5): 528-539. doi: doi:10.1093/forestry/cpv019.

Rocca, M.; Brown, P.; MacDonald, L.; [et al.]. 2014. Climate change impacts on fire regimes and key ecosystem services in Rocky Mountain forests. Forest Ecology and Management. 327: 290-305. doi: 10.1016/j.foreco.2014.04.005.

Rogers, P. 2002. Using Forest Health Monitoring to assess aspen forest cover change in the southern Rockies ecoregion. Forest Ecology and Management 155:223-236. doi:10.1016/S0378-1127(01)00560-6.

Rogers, P. 2015a. Building resilience into quaking aspen management. Aspen Bibliography. Paper 7312.

Rogers, P.; Mittanck, C. 2014. Herbivory strains resilience in drought-prone aspen landscapes of the western United States. Journal of Vegetation Science. 25(2): 457-469. doi: 10.1111/jvs.12099.

Rogers, P.; Jones, A.; Catlin, J.; [et al.]. 2015. Quaking aspen in the residential-wildland interface: Elk herbivory hinders forest conservation. Natural Areas Journal. 35(3): 416-427.

Rogers, P.; Landhausser, S.; Pinno, B.; [et al.]. 2014. A functional framework for improved management of western North American aspen (Populus tremuloides Michx.). Forest Science. 60(2): 345-359. doi: 10.5849/forsci.12-156.

Rogers, P.; Leffler, A.; Ryel, R. 2010. Landscape assessment of a stable aspen community in southern Utah, USA. Forest Ecology and Management. 259(3): 487-495. doi: 10.1016/j.foreco.2009.11.005. 
Romme, W.; Turner, M.; Gardner, R.; [et al.]. 1997. A rare episode of sexual reproduction in Aspen (Populus tremuloides Michx) following the 1988 Yellowstone fires. Natural Areas Journal. 17(1): 17-25.

Romme, W.; Turner, M.; Tuskan, G.; [et al.]. 2005. Establishment, persistence, and growth of aspen (Populus tremuloides) seedlings in Yellowstone National Park. Ecology. 86(2): 404-418. doi: 10.1890/03-4093.

Ryel, R.; LaMalfa, E.; Leffler, J. 2006. Water relations and water yield in aspen conifer forests. In: Restoring the West conference 2006: Aspen restoration; 2006 September 12-13; Logan, UT.

Schweiger, O.; Biesmeijer, J.; Bommarco, R.; [et al.]. 2010. Multiple stressors on biotic interactions: How climate change and alien species interact to affect pollination. Biological Reviews. 85(4): 777-795. doi: 10.1111/j.1469-185X.2010.00125.x.

Shepperd, W.; Smith, F. 1993. The role of near-surface lateral roots in the life-cycle of aspen in the central Rocky Mountains. Forest Ecology and Management. 61(1-2): 157-170. doi: 10.1016/0378-1127(93)90196-T.

Shepperd, W.; Bartos, D.; Mata, S. 2001. Above- and below-ground effects of aspen clonal regeneration and succession to conifers. Canadian Journal of Forest Research. 31(5): 739-745. doi: 10.1139/cjfr-31-5-739.

Shepperd, W.; Rogers, P.; Burton, D.; [et al.]. 2006. Ecology, biodiversity, management, and restoration of aspen in the Sierra Nevada. Gen. Tech. Rep. RMRS-GTR-178. Fort Collins, CO: U.S. Department of Agriculture, Forest Service, Rocky Mountain Research Station. $122 \mathrm{p}$.

Shepperd, W.; Smith, F.; Pelz, K. 2015. Group clearfell harvest can promote regeneration of aspen forests affected by sudden aspen decline in western Colorado. Forest Science. 61: 932-937.

Shepperd, W.S.; Jones, J.R. 1985. Nurse crop. In: Aspen: Ecology and management in the western United States. Gen. Tech. Rep. RM-119. Fort Collins, CO. U.S. Department of Agriculture, Forest Service, Rocky Mountain Forest and Range Experiment Station. 181-184 p.

Shinneman, D.; Baker, W.; Rogers, P.; [et al.]. 2013. Fire regimes of quaking aspen in the Mountain West. Forest Ecology and Management. 299: 22-34. doi: 10.1016/j. foreco.2012.11.032.

Smith, A.; Smith, F. 2005. Twenty-year change in aspen dominance in pure aspen and mixed aspen/conifer stands on the Uncompahgre Plateau, Colorado, USA. Forest Ecology and Management. 213(1-3): 338-348. doi: 10.1016/j.foreco.2005.03.018.

Smith, K. 1982. Drought-induced changes in avian community structure along a montane sere. Ecology. 63(4): 952-961. doi: 10.2307/1937235.

Squires, J.; Reynolds, R. 1997. Northern goshawk (Accipiter gentilis). In: Poole, A.; Gill, F., eds. The Birds of North America, No. 298. Washington, DC: The Academy of Natural Sciences; Philadelphia, PA: The American Ornithologists' Union: 1-31.

St. Clair, S.; Guyon, J.; Donaldson, J. 2010. Quaking aspen's current and future status in western North America: The role of succession, climate, biotic agents and its clonal nature. Progress in Botany. 71: 371-400. 
Stam, B.; Malechek, J.; Bartos, D.; [et al.]. 2008. Effect of conifer encroachment into aspen stands on understory biomass. Rangeland Ecology \& Management. 61(1): 93-97. doi: 10.2111/06-156R2.1.

Stewart, I. 2009. Changes in snowpack and snowmelt runoff for key mountain regions. Hydrological Processes. 23(1): 78-94. doi: 10.1002/hyp.7128.

Stewart, I.; Cayan, D.; Dettinger, M. 2005. Changes toward earlier streamflow timing across western North America. Journal of Climate. 18(8): 1136-1155. doi: 10.1175/ JCLI3321.1.

Utah Department of Agriculture and Food (UDAF). 2015. 2015 Insect Report. Salt Lake City, UT: Utah Department of Agriculture and Food. 24 p. http://ag.utah.gov/ documents/Insect_2015_InsectReport.pdf.

U.S. Department of Agriculture (USDA). 2013a. Existing Vegetation Types. LANDFIRE. Washington, DC: U.S. Department of Agriculture, Forest Service; U.S. Department of the Interior. http://www.landfire.gov/vegetation.php.

U.S. Department of Agriculture (USDA). 2013b. Wildland fire hazard potential (WFP) for the conterminous United States. Missoula, MT: U.S. Department of Agriculture, Forest Service, Rocky Mountain Research Station, Fire Sciences Laboratory, Fire Modeling Institute (FMI). http://www.firelab.org/project/wildland-fire-potential.

U.S. Department of Agriculture (USDA). 2015. USDA Plants Database. United States Department of Agriculture, Natural Resource Conservation Service. https://plants. usda.gov/java.

U.S. Geological Survey (USGS). 2014. National Elevation Dataset Digital Elevation Model. Washington, DC: U.S. Department of the Interior, U.S. Geological Survey. http://nationalmap.gov/

Villalba, J.; Burritt, E.; St. Clair, S. 2014. Aspen (Populus tremuloides Michx.) intake and preference by mammalian herbivores: The role of plant secondary compounds and nutritional context. Journal of Chemical Ecology. 40(10): 1135-1145. doi: 10.1007/s10886-014-0507-0.

Walters, J.; Hinds, T.; Johnson, D.; [et al.]. 1982. Effects of partial cutting on diseases, mortality, and regeneration of Rocky Mountain aspen stands. Aspen Bibliography. Paper 4226. http://digitalcommons.usu.edu/aspen_bib/4226.

Wan, H.; Olson, A.; Muncey, K.; [et al.]. 2014. Legacy effects of fire size and severity on forest regeneration, recruitment, and wildlife activity in aspen forests. Forest Ecology and Management. 329: 59-68. doi: 10.1016/j.foreco.2014.06.006.

Wan, H.; Rhodes, A.; St. Clair, S. 2014. Fire severity alters plant regeneration patterns and defense against herbivores in mixed aspen forests. Oikos. 123(12): 1479-1488. doi: 10.1111/oik.01521.

Warren, S.D.; Harper, K.T.; Booth, G.M. 1988. Elevational distribution of insect pollinators. American Midland Naturalist. 120(2): 325-330.

Westerling, A.; Brown, T.; Schoennagel, T.; [et al.]. 2014. Briefing: Climate and wildfire in western U.S. forests. In: Sample, V. Alaric; Bixler, R. Patrick, eds. Forest conservation and management in the Anthropocene: Conference proceedings. Proceedings RMRS-P-71. Fort Collins, CO: U.S. Department of Agriculture, Forest Service. Rocky Mountain Research Station: 81-102. 
Willmer, P. 2012. Ecology: Pollinator-plant synchrony tested by climate change. Current Biology. 22(4): R131-R132. doi: 10.1016/j.cub.2012.01.009.

Worrall, J.; Marchetti, S.; Egeland, L.; [et al.]. 2010. Effects and etiology of sudden aspen decline in southwestern Colorado, USA. Forest Ecology and Management. 260(5): 638-648. doi: 10.1016/j.foreco.2010.05.020.

Worrall, J.; Marchetti, S.; Rehfeldt, G. 2014. Sudden aspen decline. A report for Spruce Beetle Epidemic and Aspen Decline Management Responses EIS. 18 p. http:// upartnership.org/wp-content/uploads/2012/01/SAD-SBEADMR-Jim-Worral-whitepaper1.pdf.

Worrall, J.; Mask, R.; Eager, T.; [et al.]. 2008. Sudden aspen decline in southwest Colorado. Phytopathology. 98(6): S173-S173.

Worrall, J.; Rehfeldt, G.; Hamann, A.; [et al.]. 2013. Recent declines of Populus tremuloides in North America linked to climate. Forest Ecology and Management. 299: 35-51. doi: 10.1016/j.foreco.2012.12.033.

Wuebbles, D.; Meehl, G.; Hayhoe, K.; [et al.]. 2014. CMIP5 climate model analyses: Climate extremes in the United States. Bulletin of the American Meteorological Society. 95(4): 571-583. doi: 10.1175/BAMS-D-12-00172.1.

Yue, X.; Mickley, L.; Logan, J.; [et al.]. 2013. Ensemble projections of wildfire activity and carbonaceous aerosol concentrations over the western United States in the mid-21st century. Atmospheric Environment. 77: 767-780. doi: 10.1016/j. atmosenv.2013.06.003.

Zier, J.; Baker, W. 2006. A century of vegetation change in the San Juan Mountains, Colorado: An analysis using repeat photography. Forest Ecology and Management. 228(1-3): 251-262. doi: 10.1016/j.foreco.2006.02.049.

Zobell, R.; Goodrich, S. 2015. Aspen trend north slope Uinta Mountains. Unpublished document on file with: U.S. Department of Agriculture, Forest Service, Ashley National Forest, Vernal, UT. 37 slides. 


\section{Appendix A-Aspen Ecosystem Vulnerability Assessment}

\section{Vulnerability Assessment Development Process}

The information in this literature-based vulnerability assessment involved three sets of reviews to vet the structure and content of the information:

- A first draft was compiled based on searches of literature relevant to the seven vulnerability criteria (table A1) for aspen ecosystems. Information was interpreted and synthesized to pull out key points relevant to the vulnerability criteria. This draft was reviewed by the Uinta-Wasatch-Cache and Ashley National Forests staff. Suggestions for structure of content and ecological information specific to the Uinta-Wasatch-Cache and Ashley National Forests were implemented in a second draft.

- The second draft was reviewed by experts and suggestions for clarifications and additions of scientific information. Their assessment of vulnerability scores for each criterion was incorporated in a third draft.

- The third draft was reviewed by the Uinta-Wasatch-Cache and Ashley National Forests staff before submission to publication.

\section{Summary of Uinta-Wasatch-Cache and Ashley National Forests Aspen Ecosystem Vulnerability}

Climate change vulnerability across the indicators was derived from the qualitative literature summaries of available science. Categories for each of the seven vulnerability criteria spanned from moderate to very high with overall vulnerability of aspen ecosystems as moderate. Sensitivity to Extreme Climatic Events and Likelihood of Managing or Alleviating Climate Change Effects was assigned High vulnerability, and all other criteria were assigned a moderate rating. The average of these seven criteria fall in the moderate category.

Table A1-Wasatch Range and Uinta Mountain vulnerability score by criteria and the overall vulnerability score.

\begin{tabular}{|l|l|}
\hline Vulnerability criteria & Vulnerability \\
\hline Range shift capacity & Moderate \\
\hline Vulnerability of cold-adapted, foundation or keystone species & Moderate \\
\hline Sensitivity to extreme climatic events & High \\
\hline Intrinsic adaptive capacity & Moderate \\
\hline Dependence on specific hydrologic condition & Moderate \\
\hline $\begin{array}{l}\text { Potential for climate change to exacerbate the effects of non- } \\
\text { climate stressors, or vice versa }\end{array}$ & Moderate \\
\hline Likelihood of managing or alleviating climate change effects & High \\
\hline Overall vulnerability & Moderate \\
\hline
\end{tabular}




\section{Appendix B-Climate Model Projections}

\section{Projections for Temperature and Precipitation (CMIP5)}

Table B1-Projected changes in temperature and precipitation from 1981-2010 to 2035-2064 for northeastern Utah Climate Division 5, combined for 231 model runs of RCP 2.6, RCP 4.5, RCP 6.0, and RCP 8.5. See figs. 6 and 7 for graphs of projections of RCP 4.5 that are not graphed below.

\begin{tabular}{|c|c|c|c|c|}
\hline \multicolumn{1}{|c|}{ Projected changes by $2035-2064^{\mathrm{a}}$} & Mean & 10th & 50th & 90th \\
\hline Change in annual average temperature ( $\left.{ }^{\circ} \mathrm{F}\right)$ & $\mathbf{3 . 8}$ & 2.2 & 3.7 & 5.8 \\
\hline Change in annual average precipitation (\%) & $\mathbf{4 . 0}$ & -6.0 & 3.1 & 14.4 \\
\hline
\end{tabular}

${ }^{a}$ Projections are based on 231 model runs from 1/8 ${ }^{\circ}$ CMIP5 BCSD (bias-correction and spatial disaggregation) including all Representative Concentration Pathways (RCPs). See Appendix C for Models. Accessed from: http://gdo-dcp.ucllnl.org/downscaled cmip projections/ dcplnterface.html.

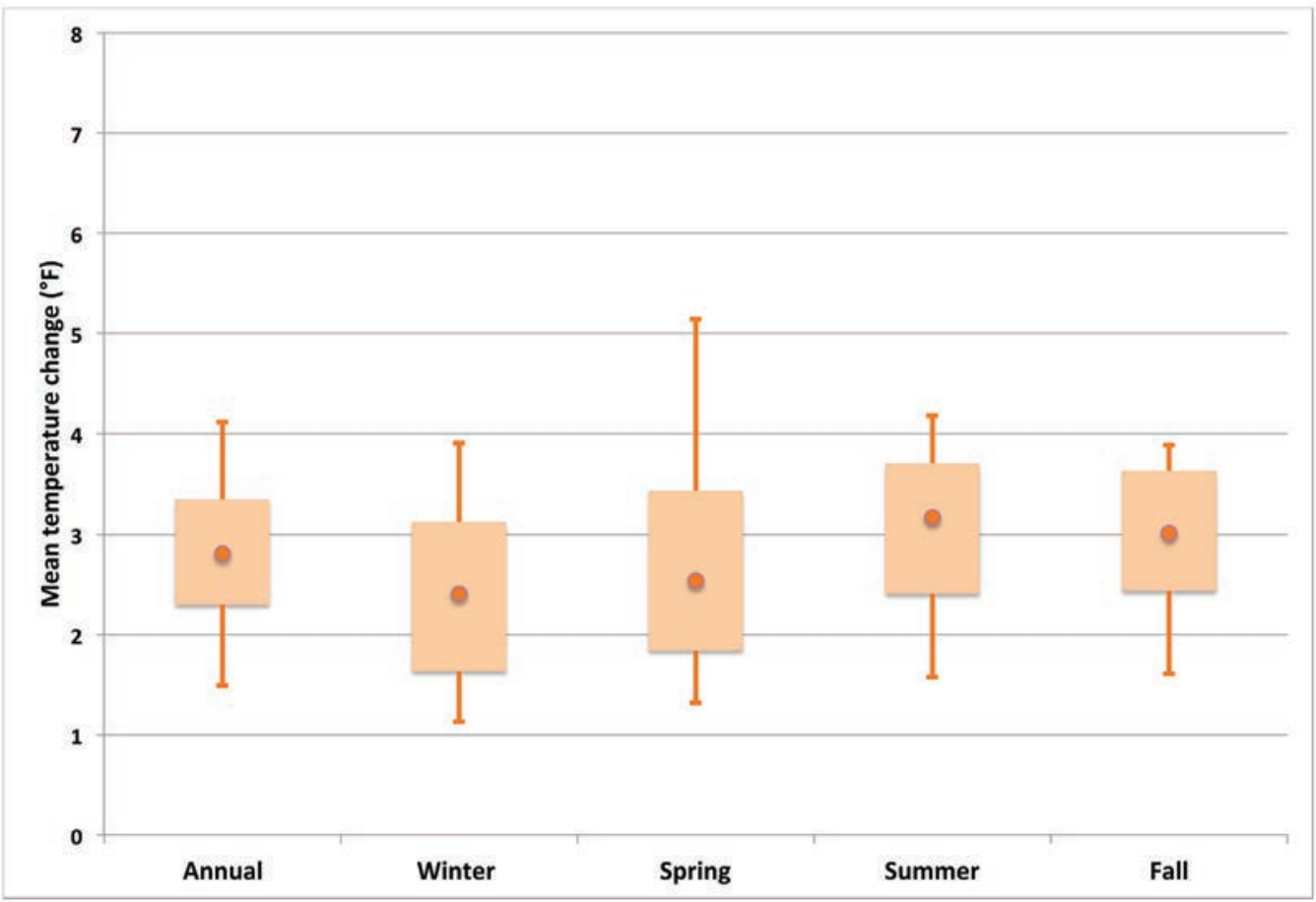

Figure B1-Annual and seasonal temperature change projections for 2035-2064 relative to 1981-2010 for the Representative Concentration Pathway (RCP) 2.6. There are 53 model runs included in this projection. 


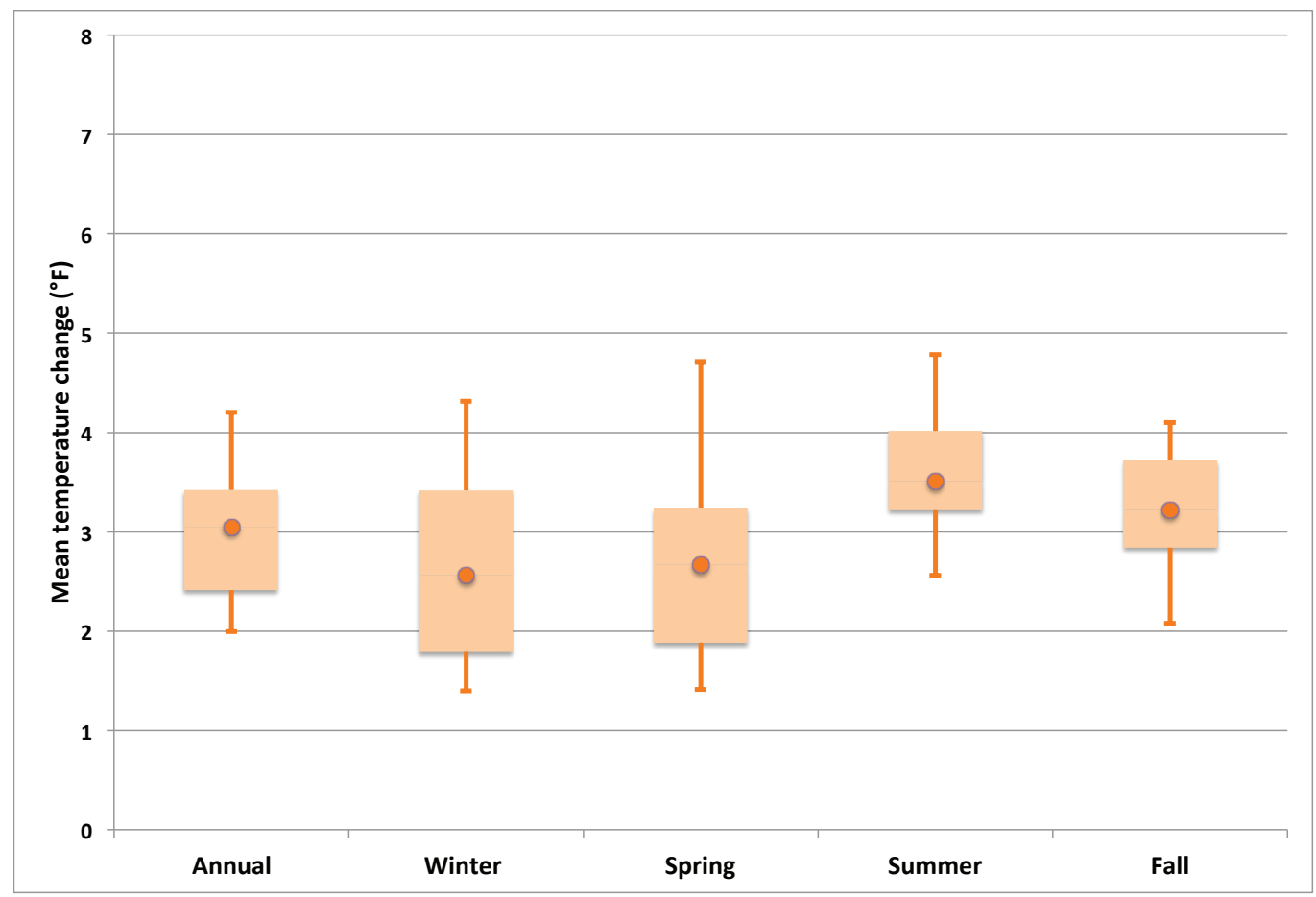

Figure B2-Annual and seasonal temperature change projections for 2035-2064 relative to 1981-2010 for the Representative Concentration Pathway (RCP) 6.0. There are 37 model runs included in this projection.

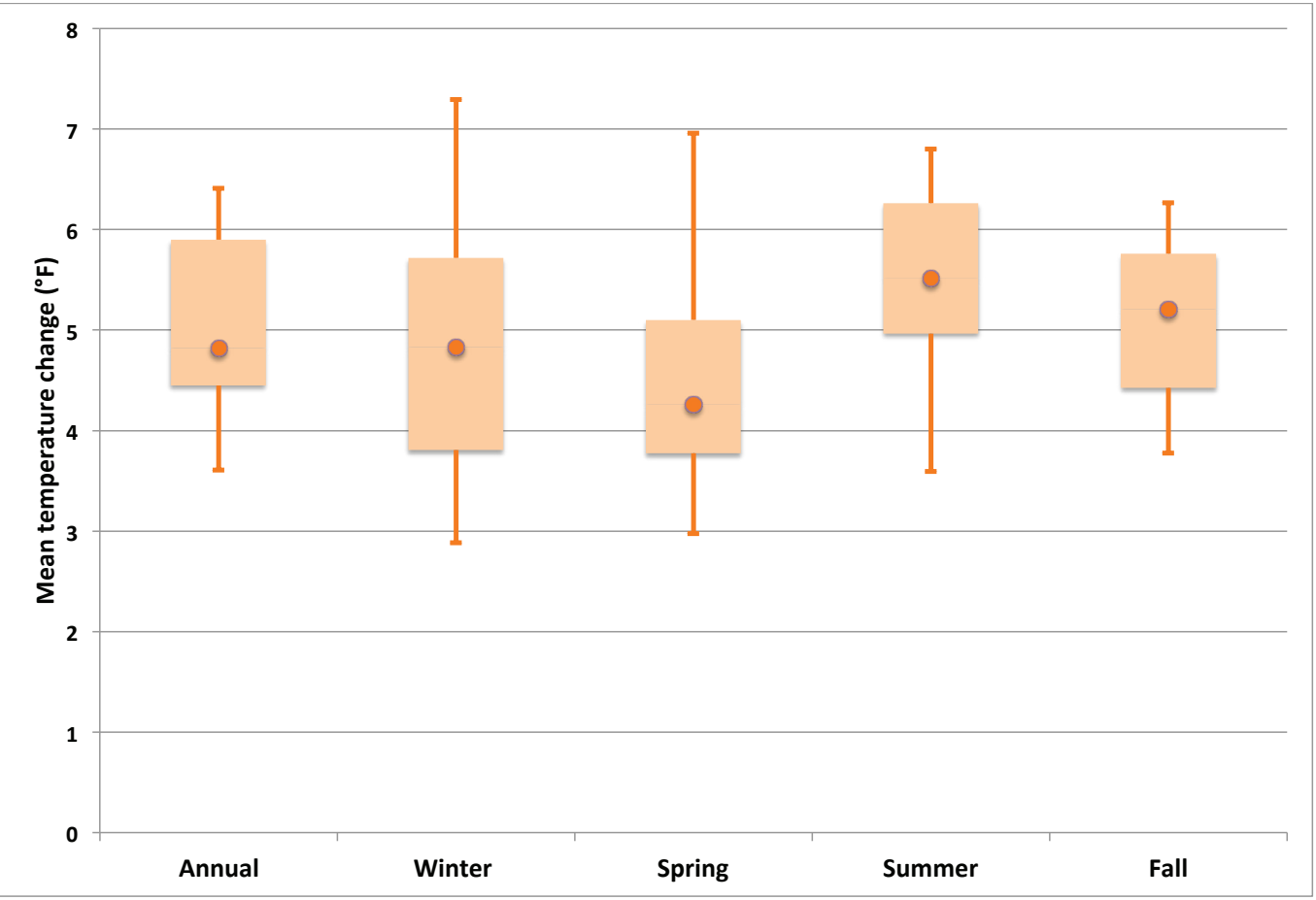

Figure B3-Annual and Seasonal temperature change projections for 2035-2064 relative to 1981-2010 for the Representative Concentration Pathway (RCP) 8.5. There are 70 model runs included in this projection. 


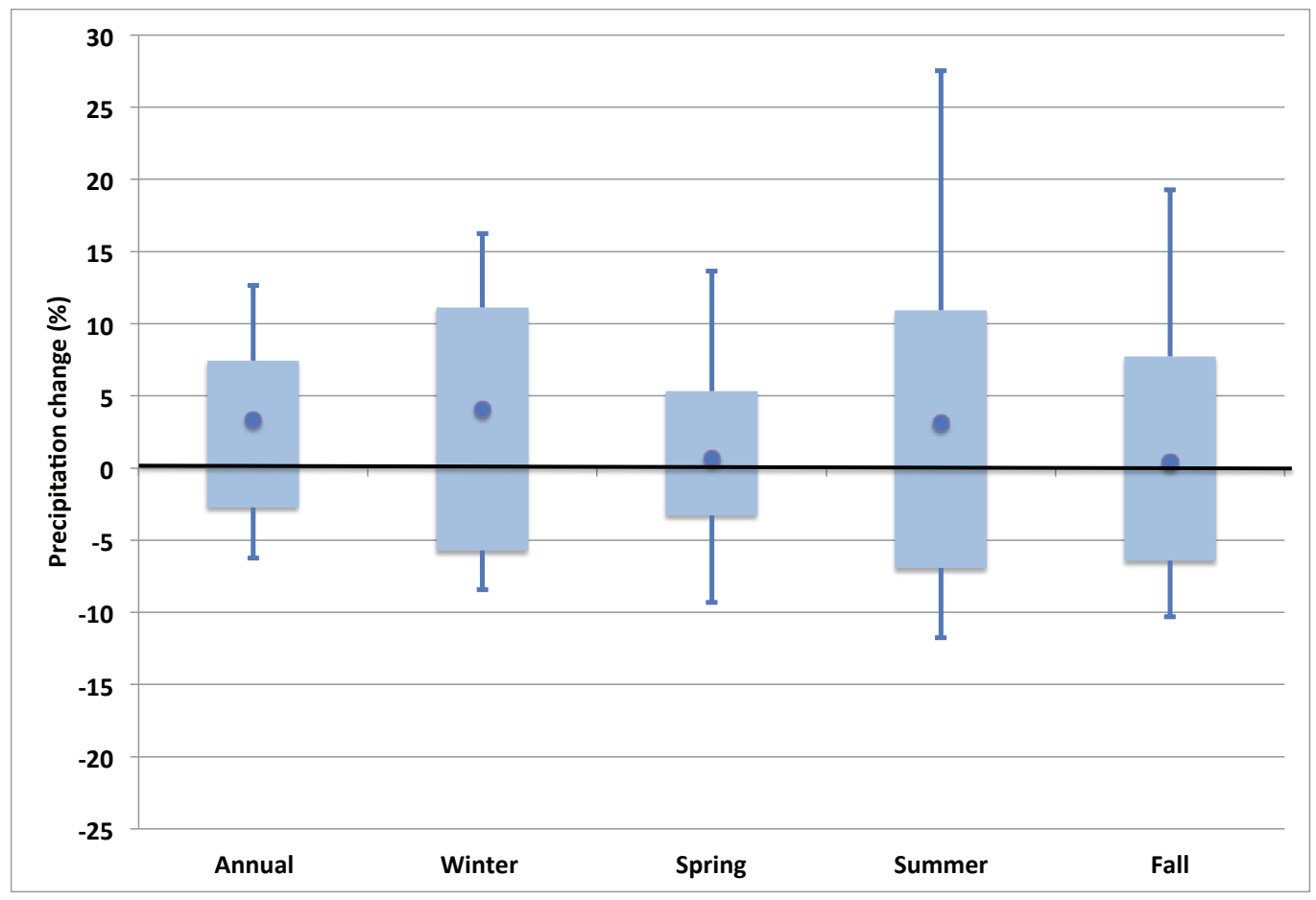

Figure B4-Annual and seasonal precipitation percent change projection for 2035-2064 relative to 19812010 for the Representative Concentration Pathway (RCP) 2.6. There are 53 model runs included in this projection.

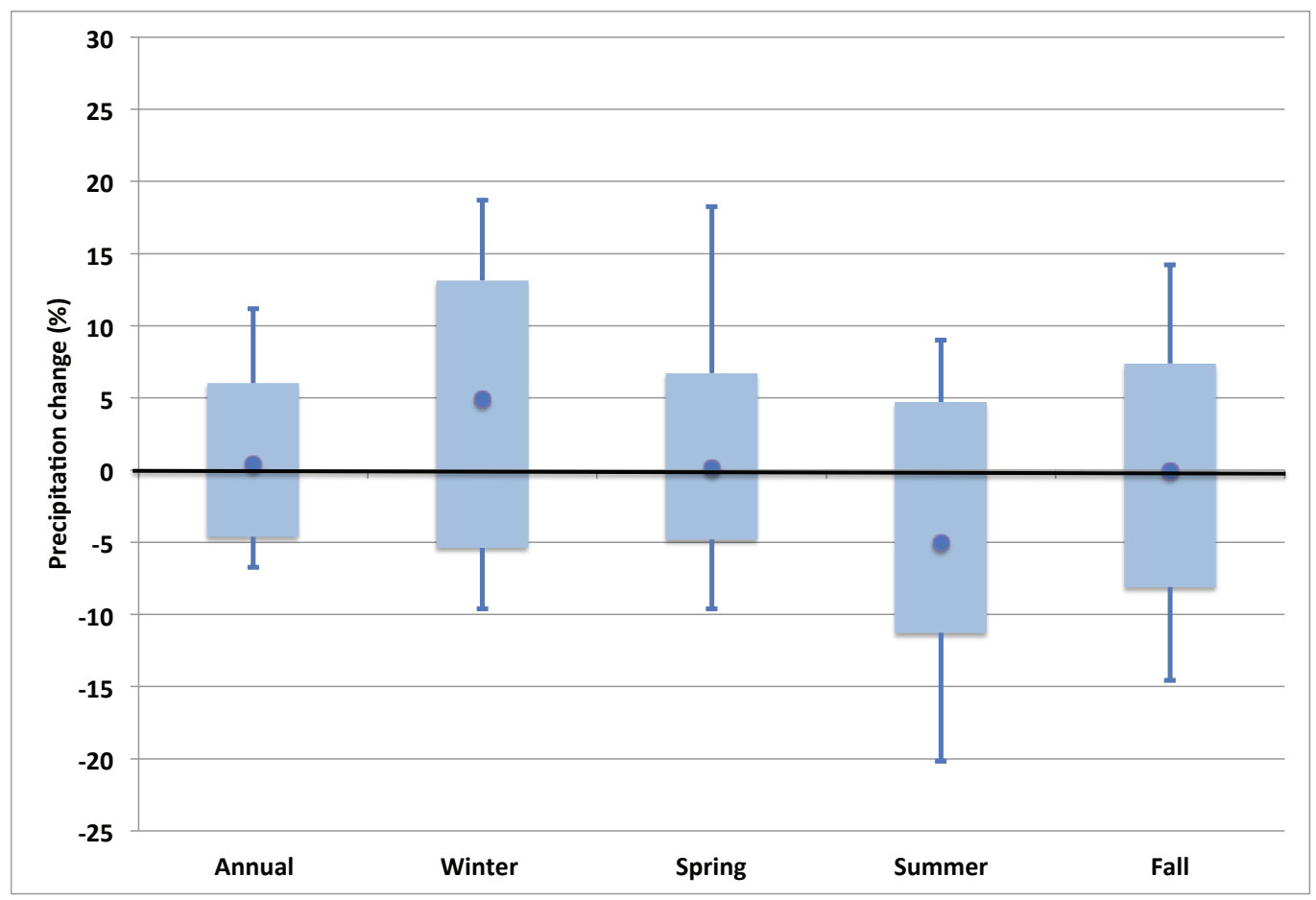

Figure B5-Annual and seasonal precipitation percent change projection for 2035-2064 relative to 19812010 for the Representative Concentration Pathway (RCP) 6.0. There are 37 model runs included in this projection. 


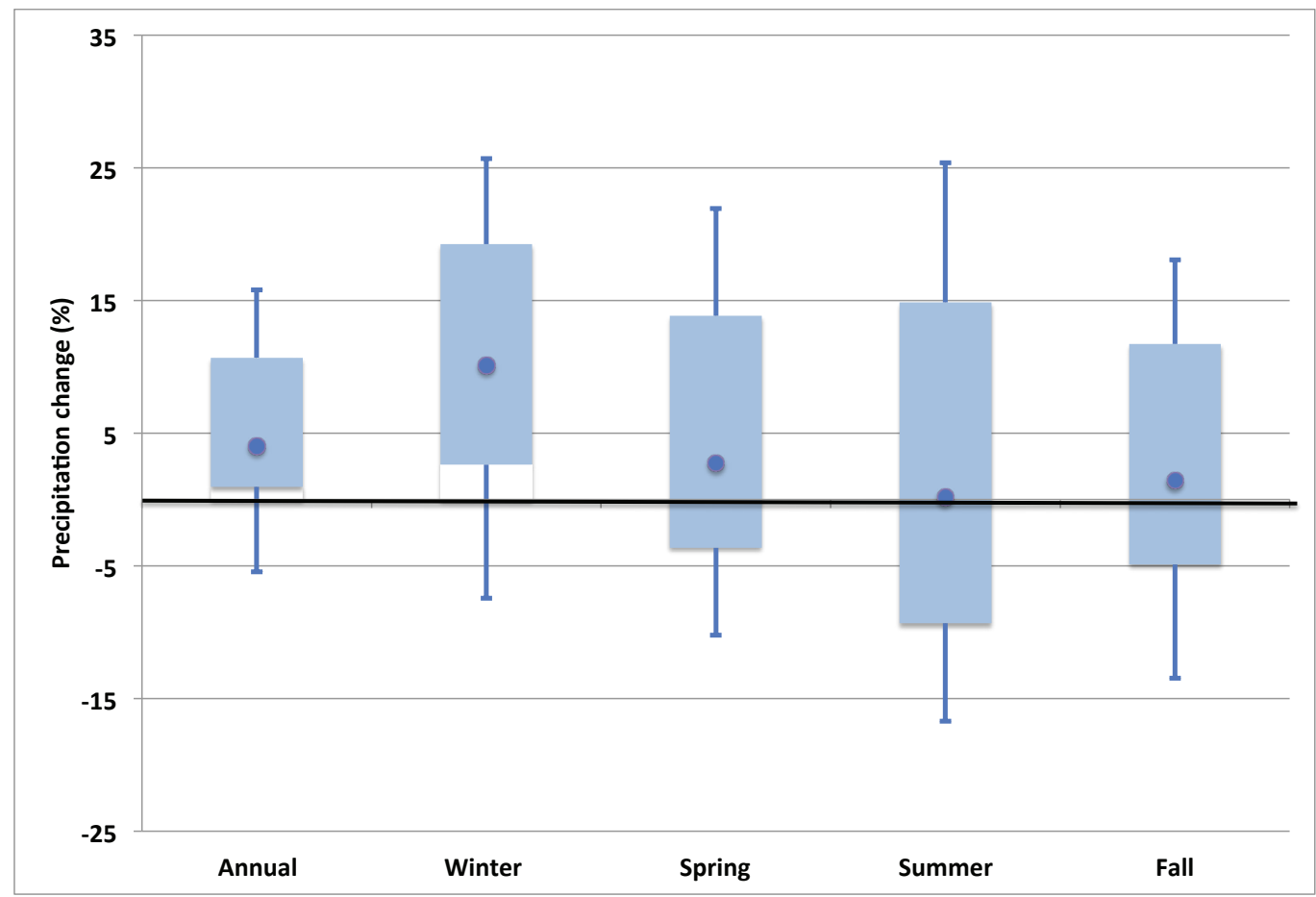

Figure B6-Annual and seasonal precipitation percent change projection for 2035-2064 relative to 19812010 for the Representative Concentration Pathway (RCP) 8.5. There are 70 model runs included in this RCP projection. 


\section{Appendix C-Coupled Model Intercomparison Project Phase 5}

We acknowledge the World Climate Research Programme's Working Group on Coupled Modeling, which is responsible for CMIP, and we thank the climate modeling groups (listed in table $\mathrm{C} 1$ of this paper) for producing and making available their model output. For CMIP, the U.S. Department of Energy's Program for Climate Model Diagnosis and Intercomparison provides coordinating support and led development of software infrastructure in partnership with the Global Organization for Earth System Science Portals.

Table C1—Climate Modeling Groups for CMIP5.

\begin{tabular}{|c|c|c|}
\hline Modeling center (or Group) & Institute ID & Model name \\
\hline $\begin{array}{l}\text { Commonwealth Scientific and Industrial Research Organization } \\
\text { (CSIRO) and Bureau of Meteorology (BOM), Australia }\end{array}$ & CSIRO-BOM & $\begin{array}{l}\text { ACCESS1.0 } \\
\text { ACCESS1.3 }\end{array}$ \\
\hline Beijing Climate Center, China Meteorological Administration & BCC & $\begin{array}{c}\text { BCC-CSM1.1 } \\
\text { BCC-CSM1.1(m) }\end{array}$ \\
\hline $\begin{array}{l}\text { Instituto Nacional de Pesquisas Espaciais (National Institute for } \\
\text { Space Research) }\end{array}$ & INPE & BESM OA $2.3^{a}$ \\
\hline $\begin{array}{l}\text { College of Global Change and Earth System Science, Beijing } \\
\text { Normal University }\end{array}$ & GCESS & BNU-ESM \\
\hline Canadian Centre for Climate Modelling and Analysis & CCCMA & $\begin{array}{l}\text { CanESM2 } \\
\text { CanCM4 } \\
\text { CanAM4 }\end{array}$ \\
\hline University of Miami - RSMAS & RSMAS & CCSM4(RSMAS) \\
\hline National Center for Atmospheric Research & NCAR & CCSM4 \\
\hline Community Earth System Model Contributors & NSF-DOE-NCAR & $\begin{array}{c}\text { CESM1(BGC) } \\
\text { CESM1(CAM5) } \\
\text { CESM1(CAM5.1,FV2) } \\
\text { CESM1(FASTCHEM) } \\
\text { CESM1(WACCM) }\end{array}$ \\
\hline $\begin{array}{l}\text { Center for Ocean-Land-Atmosphere Studies and National Cen- } \\
\text { ters for Environmental Prediction }\end{array}$ & COLA and NCEP & CFSv2-2011 \\
\hline Centro Euro-Mediterraneo per I Cambiamenti Climatici & CMCC & $\begin{array}{l}\text { CMCC-CESM } \\
\text { CMCC-CM } \\
\text { CMCC-CMS }\end{array}$ \\
\hline \multirow{2}{*}{$\begin{array}{l}\text { Centre National de Recherches Météorologiques / Centre Eu- } \\
\text { ropéen de Recherche et Formation Avancée en Calcul Scienti- } \\
\text { fique }\end{array}$} & \multirow{2}{*}{ CNRM-CERFACS } & CNRM-CM5 \\
\hline & & CNRM-CM5-2 \\
\hline $\begin{array}{l}\text { Commonwealth Scientific and Industrial Research Organiza- } \\
\text { tion in collaboration with Queensland Climate Change Centre of } \\
\text { Excellence }\end{array}$ & CSIRO-QCCCE & CSIRO-Mk3.6.0 \\
\hline EC-EARTH consortium & EC-EARTH & EC-EARTH \\
\hline $\begin{array}{l}\text { LASG, Institute of Atmospheric Physics, Chinese Academy of } \\
\text { Sciences and CESS, Tsinghua University }\end{array}$ & LASG-CESS & FGOALS-g2 \\
\hline
\end{tabular}




\begin{tabular}{|c|c|c|}
\hline $\begin{array}{l}\text { LASG, Institute of Atmospheric Physics, Chinese Academy of } \\
\text { Sciences }\end{array}$ & LASG-IAP & $\begin{array}{l}\text { FGOALS-gl } \\
\text { FGOALS-s2 }\end{array}$ \\
\hline The First Institute of Oceanography, SOA, China & $\mathrm{FIO}$ & FIO-ESM \\
\hline NASA Global Modeling and Assimilation Office & NASA GMAO & GEOS-5 \\
\hline NOAA Geophysical Fluid Dynamics Laboratory & NOAA GFDL & $\begin{array}{c}\text { GFDL-CM2.1 } \\
\text { GFDL-CM3 } \\
\text { GFDL-ESM2G } \\
\text { GFDL-ESM2M } \\
\text { GFDL-HIRAM-C180 } \\
\text { GFDL-HIRAM-C360 }\end{array}$ \\
\hline NASA Goddard Institute for Space Studies & NASA GISS & $\begin{array}{l}\text { GISS-E2-H } \\
\text { GISS-E2-H-CC } \\
\text { GISS-E2-R } \\
\text { GISS-E2-R-CC }\end{array}$ \\
\hline $\begin{array}{l}\text { National Institute of Meteorological Research/Korea Meteoro- } \\
\text { logical Administration }\end{array}$ & NIMR/KMA & HadGEM2-AO \\
\hline $\begin{array}{l}\text { Met Office Hadley Centre (additional HadGEM2-ES realizations } \\
\text { contributed by Instituto Nacional de Pesquisas Espaciais) }\end{array}$ & $\begin{array}{l}\text { MOHC } \\
\text { (additional realiza- } \\
\text { tions by INPE) }\end{array}$ & $\begin{array}{l}\text { HadCM3 } \\
\text { HadGEM2-CC } \\
\text { HadGEM2-ES } \\
\text { HadGEM2-A }\end{array}$ \\
\hline Institute for Numerical Mathematics & INM & INM-CM4 \\
\hline Institut Pierre-Simon Laplace & IPSL & $\begin{array}{l}\text { IPSL-CM5A-LR } \\
\text { IPSL-CM5A-MR } \\
\text { IPSL-CM5B-LR }\end{array}$ \\
\hline $\begin{array}{l}\text { Japan Agency for Marine-Earth Science and Technology, Atmo- } \\
\text { sphere and Ocean Research Institute (The University of Tokyo), } \\
\text { and National Institute for Environmental Studies }\end{array}$ & MIROC & $\begin{array}{l}\text { MIROC-ESM } \\
\text { MIROC-ESM-CHEM }\end{array}$ \\
\hline $\begin{array}{l}\text { Atmosphere and Ocean Research Institute (The University of } \\
\text { Tokyo), National Institute for Environmental Studies, and Japan } \\
\text { Agency for Marine-Earth Science and Technology }\end{array}$ & MIROC & $\begin{array}{l}\text { MIROC4h } \\
\text { MIROC5 }\end{array}$ \\
\hline $\begin{array}{l}\text { Max-Planck-Institut für Meteorologie (Max Planck Institute for } \\
\text { Meteorology) }\end{array}$ & MPI-M & $\begin{array}{l}\text { MPI-ESM-MR } \\
\text { MPI-ESM-LR } \\
\text { MPI-ESM-P }\end{array}$ \\
\hline Meteorological Research Institute & MRI & $\begin{array}{l}\text { MRI-AGCM3.2H } \\
\text { MRI-AGCM3.2S } \\
\text { MRI-CGCM3 } \\
\text { MRI-ESM1 }\end{array}$ \\
\hline Nonhydrostatic Icosahedral Atmospheric Model Group & NICAM & NICAM.09 \\
\hline Norwegian Climate Centre & NCC & $\begin{array}{l}\text { NorESM1-M } \\
\text { NorESM1-ME }\end{array}$ \\
\hline
\end{tabular}

${ }^{a}$ Model output not yet available. 
In accordance with Federal civil rights law and U.S. Department of Agriculture (USDA) civil rights regulations and policies, the USDA, its Agencies, offices, and employees, and institutions participating in or administering USDA programs are prohibited from discriminating based on race, color, national origin, religion, sex, gender identity (including gender expression), sexual orientation, disability, age, marital status, family/parental status, income derived from a public assistance program, political beliefs, or reprisal or retaliation for prior civil rights activity, in any program or activity conducted or funded by USDA (not all bases apply to all programs). Remedies and complaint filing deadlines vary by program or incident.

Persons with disabilities who require alternative means of communication for program information (e.g., Braille, large print, audiotape, American Sign Language, etc.) should contact the responsible Agency or USDA's TARGET Center at (202) 720-2600 (voice and TTY) or contact USDA through the Federal Relay Service at (800) 877-8339. Additionally, program information may be made available in languages other than English.

To file a program discrimination complaint, complete the USDA Program Discrimination Complaint Form, AD-3027, found online at http://www.ascr.usda.gov/complaint_filing_ cust.html and at any USDA office or write a letter addressed to USDA and provide in the letter all of the information requested in the form. To request a copy of the complaint form, call (866) 632-9992. Submit your completed form or letter to USDA by: (1) mail: U.S. Department of Agriculture, Office of the Assistant Secretary for Civil Rights, 1400 Independence Avenue, SW, Washington, D.C. 20250-9410; (2) fax: (202) 690-7442; or (3) email: program.intake@usda.gov. 